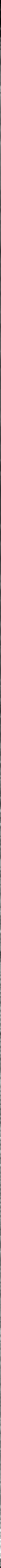




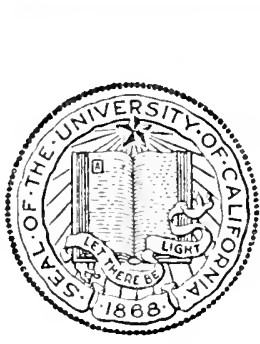

THE LIBRARY

OF

THE UNIVERSITY

OF CALIFORNIA

LOS ANGELES 

ANCIENT STONE CROSSES

OF ENGLAND 



\section{ANCIENT STONE CROSSES OF ENGLAND}

BY ALFRED RIMMER

WITI SEIENTITHO ILLLSTRATIOAS OV WOOI

\section{LONDON}

VIRTUE, SPALDING, AND $C O$. IVY LANE, PATERNOSTER ROW

$$
\text { I } \$ 75
$$


LONDON

PRINTED BY VIRTUE AND CO.

CITY ROAD 


\section{PREFATORY NOTE.}

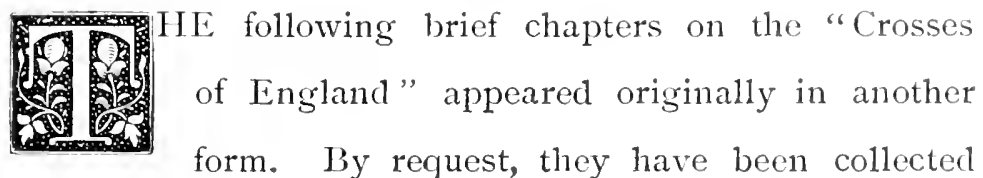

form. By request, they have been collected in the present volume, advantage being taken of the re-issue to make such emendations and corrections as a second revision would be likely to suggest.

The plan of the work being limited, the subject is treated in a popular manner-rigid scientific arrangement would have been out of place on so small a scale. For the sake of variety and interest, antiquarian notes, historical memoranda, and scraps of biography are freely blended with the text.

Much pains have been taken and expense incurred in the production of the Engravings, which, it is believed, will be found of a high character, both architecturally and pictorially. 



\section{CONTENTS.}

I.

Old English Architectme.-Adaptability of the cross for memorial purposes: its varicty of design.-Overton Cemetery.-Winchester "Butter" Cross.-Salisbury Market-Cross. - Chester High-Cross; history of its remains; annual riot at the cross.-Original motive of market-crosses.-Gilendower's Cioss.-St. Columb Cross.Stalbridge Cross.- Various uses of the cross: at cross-roads. preaching-crosses, weeping-crosses, and boundary-crosses . . I-1t

11.

Universal use of the cross in the early ages of our era.-Our inferiority to the medieval architects.-Cross at Iron-Acton; its mutilation.I'reaching-Cross of the Black Friars Monastery, Hereford; the cloisters.-The Crosses of I-ydney and Aylburton.-Restoration of Hempsted Cross. - Our Lady's Well.-The founding of the Mendicant Orders of Grey Friars and Black Friars. - The Cistercians establish themselves in England; their architectural slitll; their wealth and degeneration

III.

Destruction of roadside crosses. - Attempt to introduce the Inquisition into England.-Origin of the Spanish Inquisition ; its persecutions. -Charing Cross; satire upon its removal in the "Percy Ballads." -Bisley Cross; its antiquity; is supposed to have been erected over a well,-White Friars' Cross, Hereford.-Clearwell Cross.General form of roadside crosses.-Tottenham Cross.-Tabernacle heads to crosses.-Curious cross at O.liham.--Inscriptions on crosses 
IV.

The Eleanor Crosses.-History of Queen Eleanor; the funeral proces. PAGE sion; sites where Memorial Crosses were erected.-Former importance of Geddington; the cross.-Northampton Cross; its plan.Progress of the Procession to St. Albans and Waltham Abbey.Waltham Cross; its inscriptions.-Cheapside Cross.-Old engraving of Charing Cross

V.

Covered market-crosses; frequently met with in Canada, also in old English towns. - Malmesbury Market-Cross. - Desecration of Nalmesbury Church.- The Abbot William de Colhern.-Chichester Market-Cross; its erection and cost; its plan.-Ipswich MarketCross; suggestion for utilising similar crosses. - The Market-House at Ross, Herefordshire.-Shrewsbury Market-House.-Fourteenthcentury pulpit.-Shrewsbury Clock.-New Market-place in Chester. -Proposal to demolish the old relics at York

VI.

Newark Cross. - The Battle of Towton.-Incident during the Civil War.-Headington Cross. - The Palace of Ethelrecl-- The head of Henley Cross.-Leighton-Buzzard Cross.-The Brethren of Holyrood Cross.-Abingdon Cross; cost of repairs; the Roundheads saw down the cross.-Coventry Cross; its magnificence; its repairing and regilding; curious features of this cross.-Somersby Cross, near Horncastle.-Somersby Church . . . . . 70-8I

VII.

Instructiveness of stone crosses. - Introduction of crosses by the Christian missionaries; their striking resemblance to other remains of antiquity.-Description of the groups on the interesting old crosses at Sandbach ; their mutilation.-The crosses of Iona and Monasterboice.-Dr. Johnson and the uins of lona.-Fonmer importance of Iona as a seat of leaning.--Runic cross in the village of Bromborn 
VIII.

More ancient forms of crosses. - Cross of an Eastern character at Hillne

Island; Mr. Eckroyd Smith concerning this cross.-Remains of Runic cross found emleded in the Dec.-Curious limestone lintel. —Old Saxon cross at Eyam, Derby'shire.-Jaliewell Crosk.-Carew Cross.-Eastern Cross in Nevern Churchyard, Pembroke.-The Knights Templars.-The Cornish crosses at St. Mawgan's, Four. hole, and Forraberry.-Sueno Pillar, near Forres, Elgin . . .5 105

$1 X$

Tardy appreciation of English architecture.-Curious dialogue by Henry Peacham between the Crosses of Charing and Cheap.Remorseless sacrifice of ancient monuments to modern improvements.-The Cheddar Cliffs.-Plan of Cheddar Cross; Britton's account of this cross.-The City of Wells.-Shepton-Mallet and its cross.-Quaint old cross at Glastonbury; its singular shape and ornaments.-Glastonbury New Cross . . . . . 106-118

I.

The history of Bristol High-Cross.-The New Cross, Bristol.-The statues of Gloucester Cross.-Oaliley Grove, near Cirencester.Market-Cross of Cirencester; Roman relics found in the neighbourhood of the town.-Amusing anecdote from Camden.-Cross in the churchyard of Ampney Crucis; probability of its having been a "weeping-cross."-Cross at Wedmore, Somerset.- "Jeffreys" Cross."-Plan of Dundry Cross

\section{XI.}

Wheston Cross.-Cross at Scraptoft.-Fine old cross at Leicester.Picturesque cross at Wymondham.-The Ivy Cross at Sutton St. James.-Fourteenth-century Cross.-The Church and Cioss of Dindar.-The town of Devizes; the Market-Cross; curious legend inscribed on the cross.-Cross denouncing the married clergy.-Eltham Palace and Cross.-The town of Ludlow.Bitterley Cross; its tabernacle.-Preservation of the crosses in the Western Counties.-Crosses at Cricklade.-Tradition concerning the name of Cricklade. - Cross at Pershore . . . , 1j2-1 11 
XII.

Pentagonal Cross at Holbeach.--Old Conduit at Lincoln.-A Rebuke to Puritan zeal.-St. Mary's Cross, Lincoln-Langley Cross and Abbey-Cross in the Perpendicular style at North Petherton.Base of a cross in Bebbington Churchyard, near Chester.-Head of a cross in the grounds of Delamere Abbey.-Fosbrooke's list of the different forms of crosses.-Nonuments on the Roman highways. -The site of Idumea.-The so-called Pharaoh's Tomb.Concluding remarks 


\section{LIST OF ILLUSTRATIONS.}

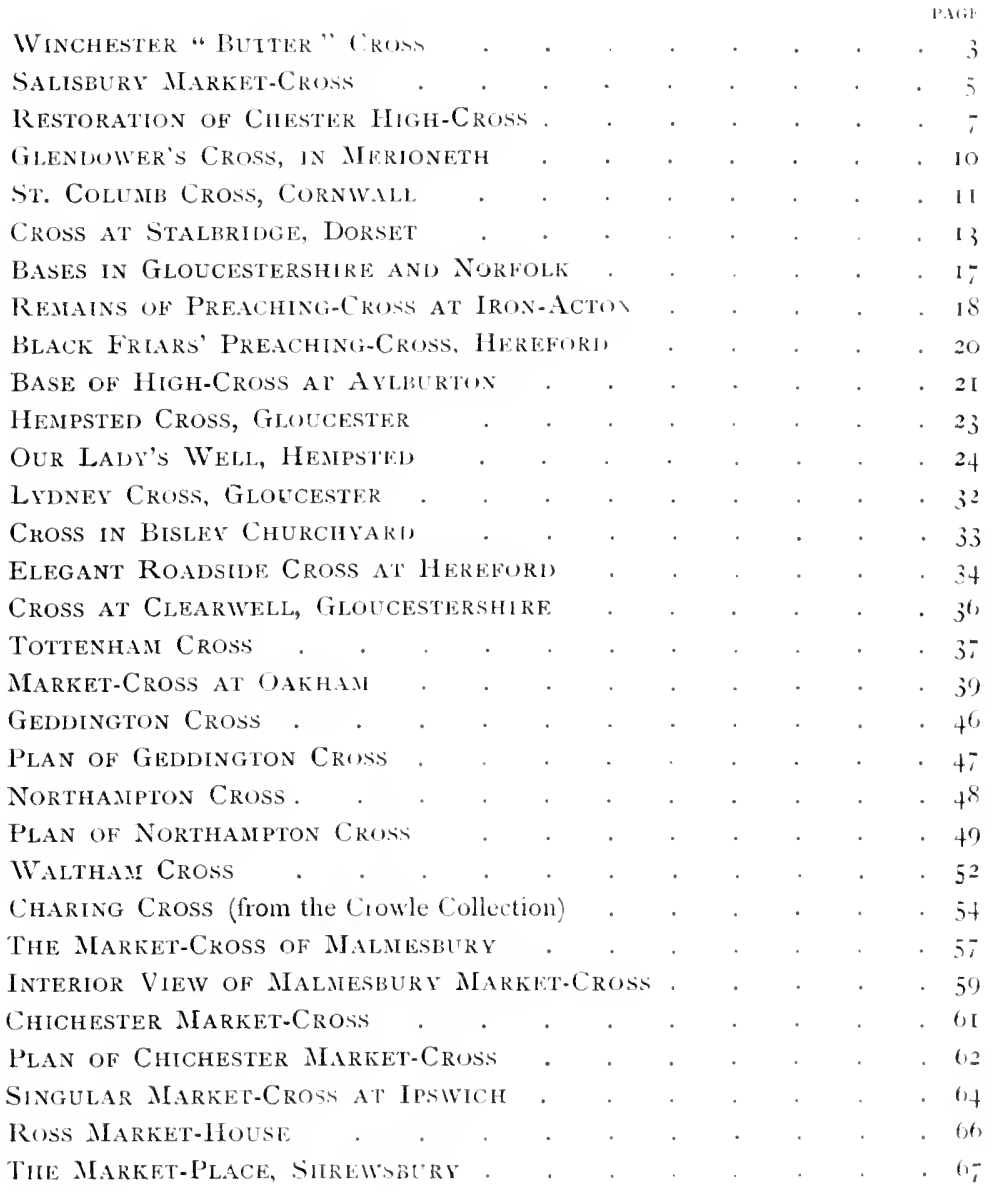




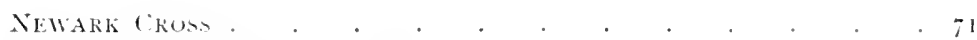

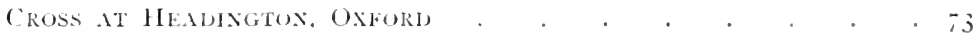

HEAI OF J I . . . . . . . . . . it

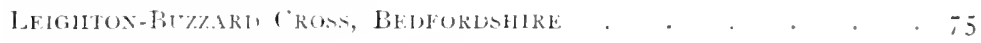

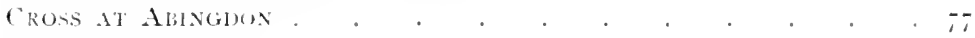

SUAERSH CkOSS . . . . . . . . . . . . . 80

Crosses AT SANDbACH, CHLSHRE . . . . . . . . . 84

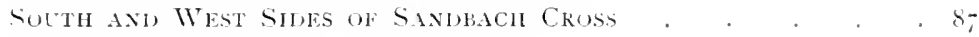

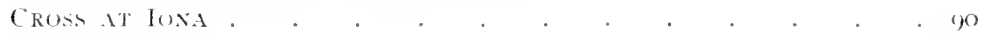

MOXATERHOLE CKUS, Lul’ill . . . . . . . 91

INCISED SLABS, CHeSTER CATHEDKAl . . . . . . . 92

BRUABURO CKon . . . . . . . . . . . 93

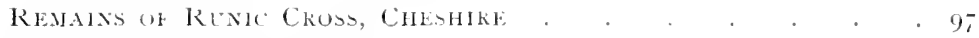

EYAM CROSS. DERBSHIKE . . . . . . . . . 9S

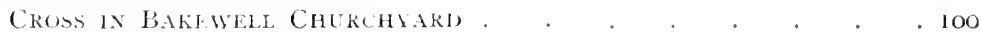

CROSS IN NEVFRN CHLRCHYARD . . . . . . . . IOI

Cokxish Cross At Fuerhule. . . . . . . . . . . 103

CROSS AT FURRAJERRY . . . . . . . . . . $10_{3}$

St, MAWGaN's CROSS, CORNWALL . . . . . . . . 104

Chednar Cross . . . . . . . . . . . I IO

Plan OF Cheinar CROSS . . . . . . . . . III

CRoss AT SHEPTON-MALLET . . . . . . . . . 114

Glastonbltri Olm Cross. . . . . . . . . . . II6

Glastoñbitr NeW Cross . . . . . . . . . . 117

The OLn CROSS, BRISTOL. . . . . . . . . . I2 I

Gloccester Crust . . . . . . . . . . . . . . . 123

CiRENCESTER CROS. . . . . . . . . . . . . . . 126

Cross at AMPNex-CkLCli . . . . . . . . . . 128

Plan OF DUNDRY CROSS. . . . . . . . . . . 130

Mheston CkOSS, DeRli . . . . . . . . . . . . . . I33

Cross at DINHAR . . . . . . . . . . . . 135

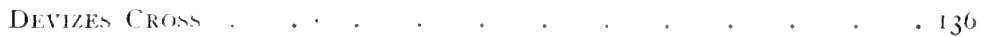

Bitterley Cross, Sillol . . . . . . . . . . . 139

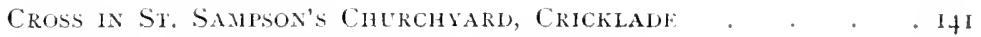

Crosi in ST. Mary's ChuRCHYARI, CRICKLAHE. . . . It2

Holblacil Cruss, lixioly . . . . . . . . . . 146

CONDUIT NEAR ST. MARY's, LINCGLN . . . . . . . I48

Cross at Langley . . . . . . . . . . . . . 150

Nokth Petherton Cross . . . . . . . . . . 151

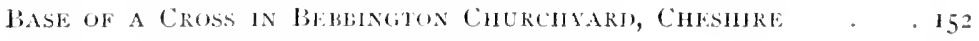

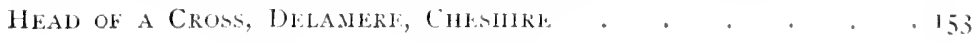




\section{MCIENT STONE (ROSSES OI ENGLANL.}

I.

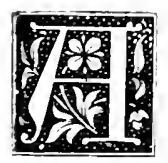

TRUE picture of England as it existed in the fourteenth and fifteenth centuries would now be regarded as the dream of an antiquary or an enthusiast. Ibbeys, churches, and crosses bristled over the land, and though for three centuries cruel war has been waged against them, there yet remain sufficient noble examples of English architecture to indicate what a wealth of grandeur and beauty has been swept away. Mr. Ruskin says even of the present day, that "the feudal and monastic buildings of Europe, and still more the streets of her ancient cities, are vanishing like dreams; and it is difficult to imagine the mingled envy and contempt with which future generations will look back to us, who still possessed such things, yet macte no effori to preserve, and scarcely any to clelineate them."

As an instance of the treasure of design that has been lost, we may mention that, of those most beautiful crosses, the Queen Eleanor memorials, only three are left-one at Gedclington, one at Northampton, and one at Waltham, 
twelve having been destroved: and these three have furnished the design for nearly all modern memorial crosses. Some very good ones have loubtless been built after the model of Watham, such as the Nartyrs' memorial at Oxford, Llam drinking-fountain, and Bishop Fulford's monument, in Nontreal Catherlral Close; and it is no disrespect to the architects to say that their success has been exactly in proportion to the fidelity with which they have adhered to their originals.

The varieties of dosign in the fow crosses that are left to us is surprising, and will form the subject of future consideration. If native English talent harl been encouraged, and if in place of modern tombs we had adhered to ancient English types, our cemeteries and graveyards might have been solemn, peaceful places, wherein we could have walked without being shocked with evidences of bad taste. Nothing is more impressive than a recumbent knight, or lady, lying on a tomb, with their hands folded as in prayer, as we may see in almost any old parish church in England; and the tall, graceful crosses that were swept away by the Puritans are just such monuments as would make a graveyard beautiful. Statues and sensational classic groups succeeded recumbent effigies, and disfigured England during the reigns of the Georges at enormous cost; while graceful crosses were superseded by unsightly and unmeaning obelisks. The vast number of monuments in Westminster Abbey that were erected during the reigns of the Georges are notorious for bad taste. Heroes and statesmen, with a fair accompaniment of heathen deities, would seem to be holding liigh revel in the venerable building. There is 
a small cemetery at (joreton, orerlonkins a beatiful hame

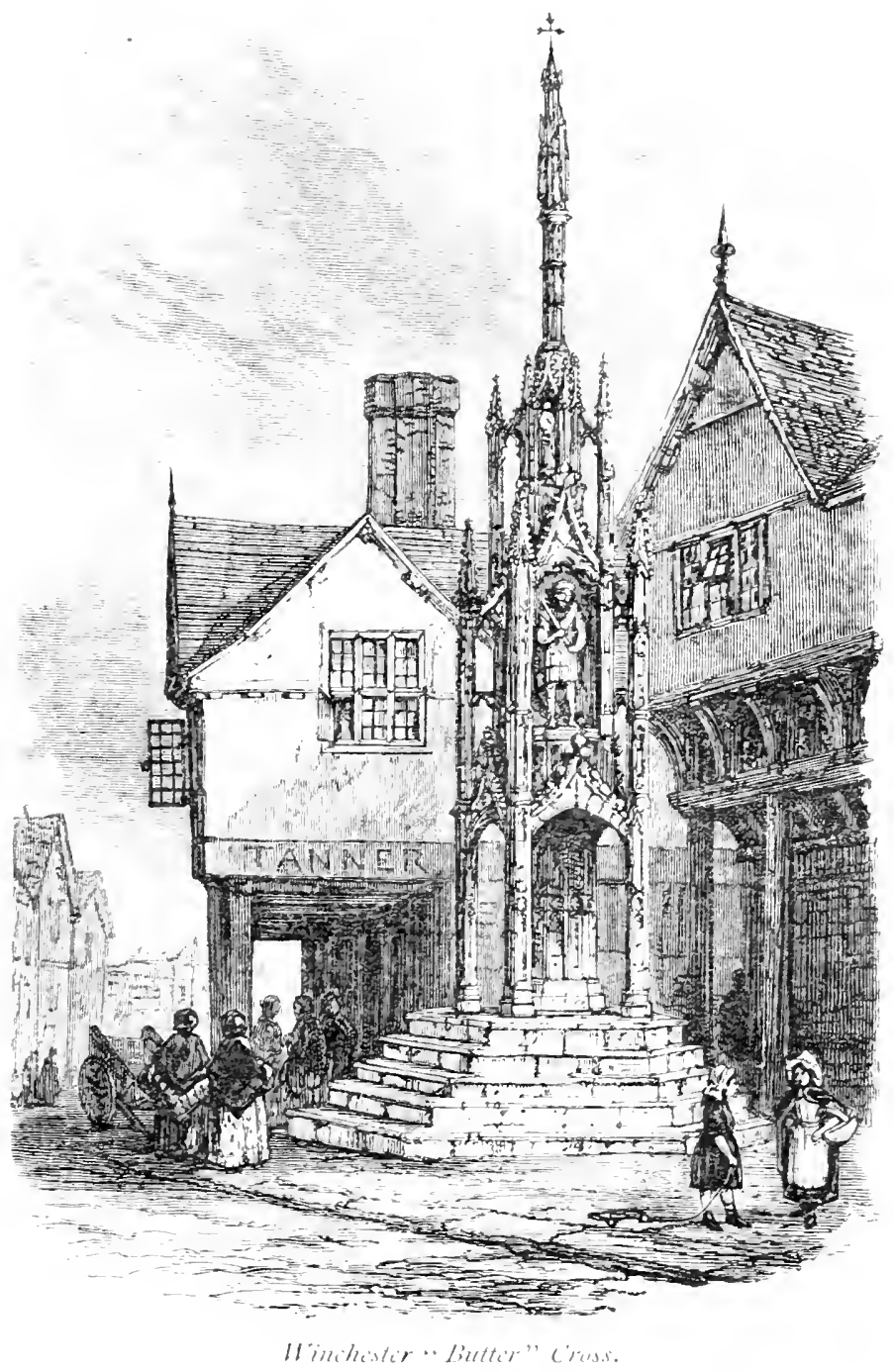

of the river l)e, which is in excellent taste. The pros prietor, it is believeel, exercises a censorship wer the. 
tumbstones: and though these are plain and simple crosses, the effect is good. Indeet, one only regrets the more that the genius of those who designed the Eleanor crosses has so completely perished out of the land.

The ancient crosses of England have been divided into Memorial, Market, Boundary, Preaching, and Weeping Crosses. The market-cross of Winchester, cngraved on the previous page, is a structure of great grace and beauty. It is called the "Butter Cross ;" scme kind of distinctive name is often applied to local market-crosses; thus that at Salisbury is called the "Poultry Cross." Milner considers it to have been erected in the roign of Henry VI., but it probably dates back as far as Edward III. Britton, writing of it only some forty years ago, says it was suffering much from the " wantonly careless practices of boys and childish men;" it is harlly credible that even in his time so meek a plea was urged for the preservation of national monuments. "This, as well as all other practices of public folly and mischievousness, should be decidedly discountenanced," he says; "for when curious memorials of antiquity are once destroyed they cannot be replaced, and almost every person, sincerely or affectedly, regrets their annihilation." This cross is about forty-five feet in height, and is now well preserved.

But Winchester is only an example of a much more capacious style of cross; it afforded accommodation for but a very few persons, and that imperfectly: the really valuable and useful covered crosses are those which, in a. much larger area, could shelter a crowd of market-people from the wet, as the crosses of Malmesbury, or Salisbury, or Chichester do at the present day. True it is they are 
only a partial shelter, and singularly inadequate to the requirements of an ordinary market-town; but circumstances have now much changed; fewer persons used to attend, and round the market-cross booths were erected

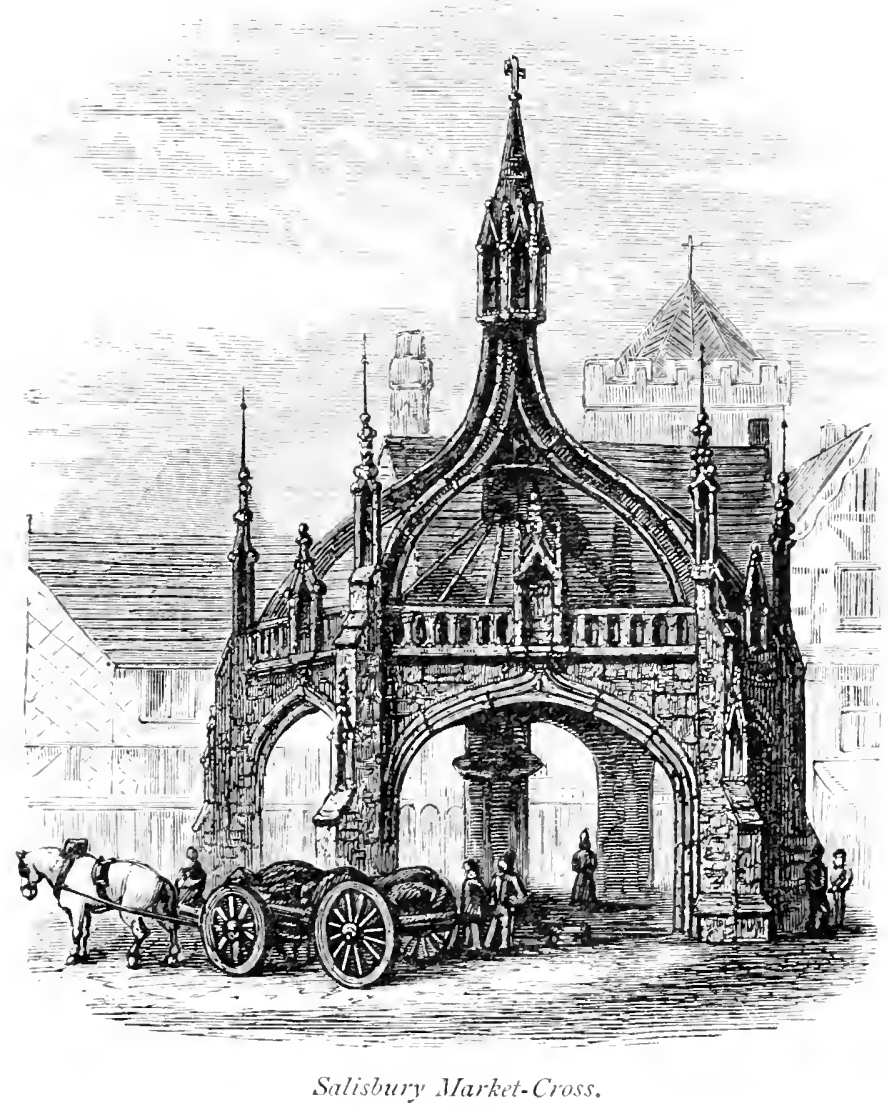

when necessary. These temporary shelters were always to be had in a town,-much more readily, indeed, than we could get them now,-and the proprietors let them, as stalls at Leadenhall are rented. 
Nothing can exced the picturesque beaty of Salisbury cross. The stone it is built of is a warm grey. It stands in a nork in the market-place. The sun lights it up fairly and well, and on a busy day it contrasts quaintly with the groups of market-carts and country people. It belongs to the few canopied crosses that are left us, and differs from (hichester and Malnesbury in many important particu lars. These marketcanopies were at one time built of aak-in counties where that timber was cheap. They may have been taken down and used for porches, or embedded in more recent buildings. It is certain that four were stantling early in this century: and it would be matter of sincere congratulation if one of these cherished relics of the past could be added to the Art-treasures of the nation; indeed, it is not tow much to hope that even some of the steme crosses may be unearthed as Chester has been; and a very few fragments would suffice, if not to restore, at least to suggest to modern arehiteets some new combinations and forms.

Chester market-cross was demolished at the general destruction of crosses, when the Cromwellites, following the example of the destroyers of monastic buildings, warred against these objects of beauty. The remains were buried near St. Peter's Church, in Chester, and about seventy years ago conveyed to Netherlegh House, where they were made into a sort of rockery in the grounds, aud, before the present proprietor came into possession, they suffered even more mutilation; enough, however, romains of them to guide us to a probable restoration, with the assistance of a rude drawing mate by Randal

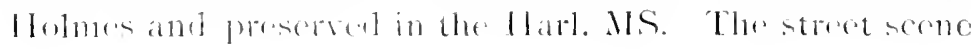


is as Chester is at present, though, of course, it differs

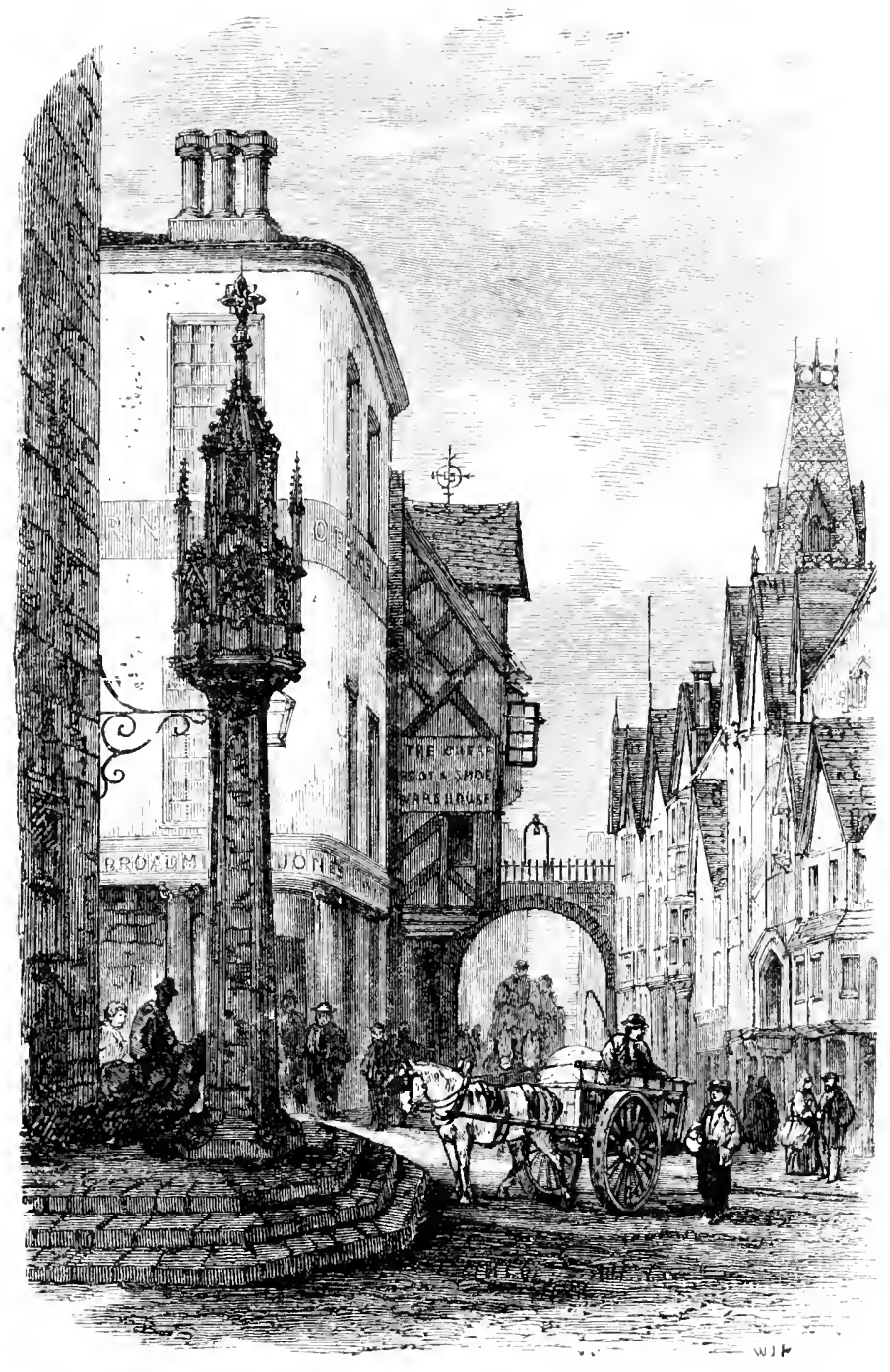

Chester:"Migh-Cross," restored fiom old fragments at lithellegh.

from the appearance of the city when the cross was stanching. There was happily a limit to the rage for 
destruction that prevailed during the period we have alluded to, and looking at some of the obvious relics left, we are led to fancy that even the soldiers of Cromwell experienced something like satiety in breaking down excellent carved work with "axes and hammers." The stone of which Chester Cross was built is very perishable, quite as much so as the Cathedral, and when Randal Holmes made his drawing it was more than two hundred years old. Under the shelter of this cross, the annual riot took place when the mayor left office. An account of one of these riots is preserved by Randal Holmes, and reflects much credit on the mayors for the conscientious way in which they prosecuted the duties of their office. In 1619 , we are told that the energies of the mayor flickered up, as it were, with his expiring dignities, and seeing a tumult, he "could not forbeare, but he went in and smote freely among them, and broke his white staff, and his crier Thomas Knowsley broke his mace, and the braw ended." The name of the dignitary, on reference to a list of the Chester mayors, seems to have been Sir R. Mainwaring. There were other crosses, however, in and around Chester at the time, which are occasionally alluded to in the earlier records of the city.

Market-crosses originated in towns where there were monastic establishments, and the "order" sent a monk or friar on market-days to preach to the assembled farming people. Probably the theme dwelt on was that they should be true and just in all their dealings, and the effect was doubtless beneficial. Milner, in his "History of Winchester," says, "The general intent of marketcrosses was to excite public homage to the religion of 
Christ crucified, and to inspire men with a sense of morality and piety amidst the ordinary transactions of life." These relics also gare the religious house a central point to collect the tolls paid by farmers and clealers in country produce for the privilege of selling in the limits of the town; and until very lately this same tax was held by certain families in Englancl, who exacted a toll from each head of cattle that was brought into the market-town for sale; indeed, it probably exists in some few remote country places at the present time. The original form of market-crosses, according to that most patient and careful investigator, Britton, was simply a stem like Chester-a tall shaft on steps; but in order to shelter the clivine who, with his collector, officiated on market-days, a covering was added, and this seems to have becn literally the way in which Cheddar Cross, in Somerset, was built. These small covered crosses were, no doubt, the origin of covered markets. There are several ancient market-places almost of a transitional kind, like the one at Shrewsbury, which was built in 1596 , and affords space for a hundred people with their produce.

The cross at Corwen, which is there called Glendower's Cross, is clearly of a much earlier date than the chieftain it is named after; there is a curious dagger cut in relief on one face which hitherto has not been accounted for. It probably terminated in a sort of Greek cross like the one at St. Columb, illustrated on page 11 . This form is common, and abounds in Cornwall and Ireland. It has been supposed to represent wicker-work, but the intersecting circle, which is finely shown in the low cross at St. Columb, was not improbably a conventional attempt 
to signify a halo. The halos round the heads of saints in pictures, even, were very solicl-looking designs. One or two more crosses of this description will be alluded to hereafter, where there is a slight variety; but as a general rule there is much sameness, and consequently only a morlified interest in them.

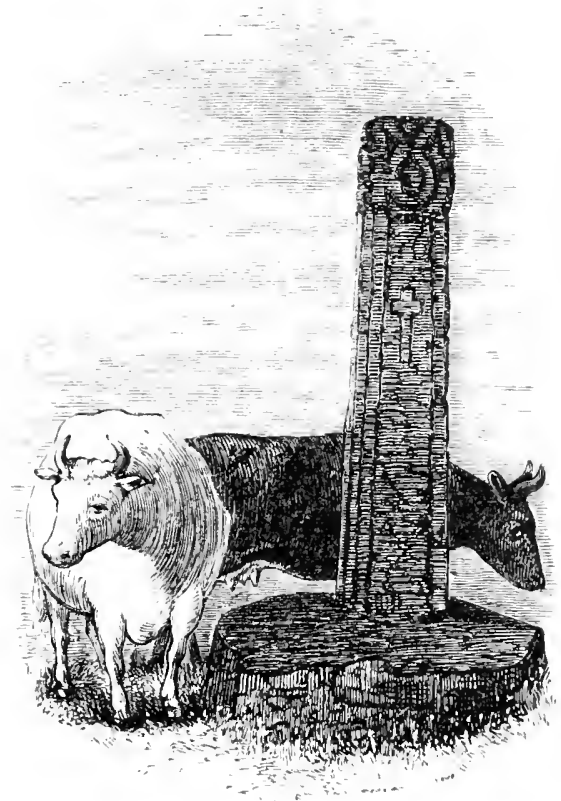

Glendoneris Cross, Merioneth.

Crosses were introduced originally, it would seem, in the southern and western parts of the island, and travelled slowly, and by no means uniformly, to the north. Mr. Blight has illustrated the antiquities of Cornwall in a very careful manner; he is of opinion that crosses are more common in the west of this country in consequence of the earliest preachers having come from Ireland; while in the 
northern parts, which were risited by Welsh missiemarjes, they are searce; at any rate, the similarity betwen the Cornish and Irish crosses is very striking.

The earliest preachers of Christianity do not seem to hate mate vident attacks upon the creeds amb beliefs of their converts. Their preaching more resemblect that of sit. l'aul at Mars llill: they printed to the greses and

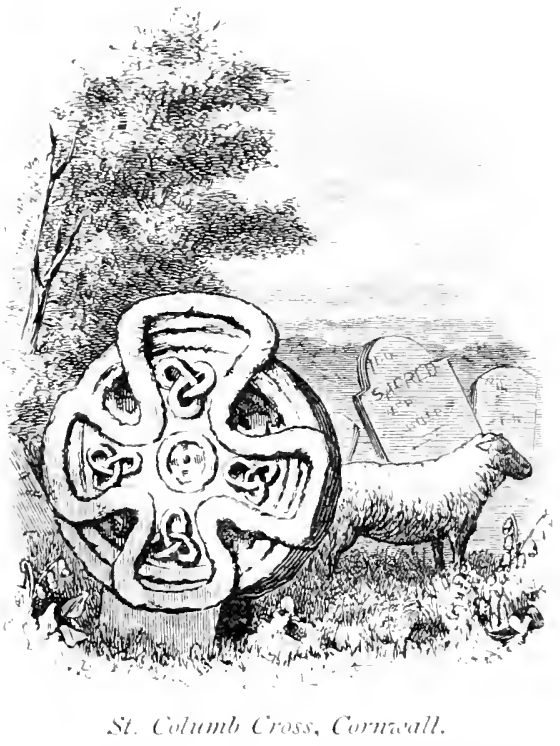

holy wells, and dedicated them in another name. Crossroads atso were held peculiarly sacred in the early times, and even as far back as the period of the Druids they were marked by upright stones, not dissimilar to those we see at Stonehenge, though, of course, much smaller, and these stones wer chiselled on the upper part with a crose in relief.

When these crosecs are near a well, an at ht. Kinne, 
they are often picturesque objects; but this is owing, generally, more to the surroundings than to any merit in clesign. The number of them near ancient wells is very great. We are led by a consideration of the Cornish crosses to speak of those at Sandbach, which are among the most perfect and the oldest examples in England. They are situated in the eastern part of Cheshire, and were probably erected at an early period of the Saxon rule. They were demolished with much persistency during the last century, great violence being necessary to destroy them; but fortunately the remains, which had been dispersed and used to ornament grottoes and doorways, were collected in 1816, and, at the suggestion of George urmerod, re-arranged in accordance with their former condition.

In taking a rapid glance in this introductory chapter, we see that market-crosses resembled the "preachingcrosses" before alluded to. There are still some beautiful remains of the latter, which seem to have been designed for the preacher to address congregations in summer weather in the open air. St. Paul's Cross, which was lestroyed by order of Cromwell, was the most celebrated preaching-cross in Europe; it was also often used for political purposes. There are remains of these crosses at Iron-Acton and Disley, in Gloucestershire, and several in Hereford; formerly they were abundant, but they commonly shared the fate of St. Paul's Cross.

boundary crosses were very important in marking the limits of parishes and manors. There are many remains of these round Chester. At Stalbriclge, in Dorsetshire, there is a good cross, thirty feet high, on three flights 
of steps, with niched figures of the Virgin, si. John, \&C.

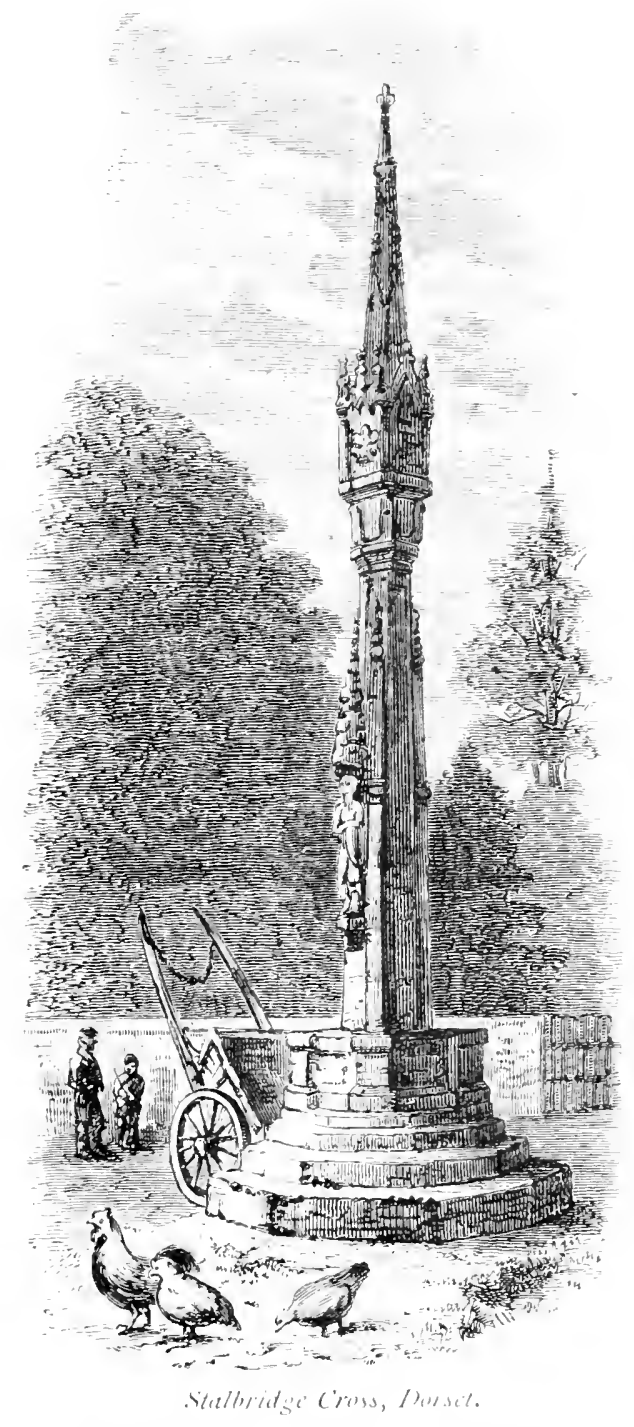

Sometimes crosses performed the important wfine of being sanctuaries. Near Delamere forest, in the midell: 
of Cheshire, are sereral ancient croses that tratition asserts were for the convenience of travellers passing through the dense wooks, where even robbers respected them, provided the former could reach the cross hirst. Memorial crosses have been already alluded to ; there are in England two of the finest, if not the very finest, in the world. Weeping-crosses were erected for the use of those who were compelted to do penance by the parish clergyman. There is an example of one of these in Flintshire, not far from 1lolywell. It is known by a Welsh name which signifies the Cross of Mourning, and was formerly supposed to mark the site of some lost battle or other event.

We see, then, from the time when crosises were introduced by the carliest preachers of Christianity into England, or from the time when Justinian ordered them to be placed in all Christian churches, to the time when they were deliberately demolished by Act of Parliament, they were applierl to many purposes, and branched out into endless forms and devices. There is hardly any limit to the variety and beauty of the crosses which atorn the gables of churches. They mark each period with precision, and so great was their number that the remains which have been spared are numerous. 


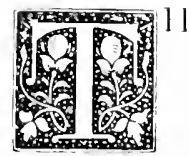

lERE were probably not frwe than fire thousand crosses in England, of the kinds alroady indicated, at the time of the Reformation; and though they may admit of some such classification as that mentioned, they must have been erected for. many other objects and on many other occasions than have been enumerated. Some crosses, for example, were supposed to have peculiar claims on certain classes; like one at King's WVeston, in Gloucestershire, most beautifully situated on the Severn, at which sailurs paid their chevotions after a voyage. This cross was celebrated far and wide; a judicious hole was cut in the stone to receive? the contributions of those who hat profited by it, or hoperl to do so. I am indebted to Canon Lysons, of Gloucester, for furnishing me with the following "xtracts, which show how universal, even at an early periol, the use of the cross was :- "Tertullian (I) Corma Iilitis), writing A.D. 199, or one hundred and twenty years before the conversion of Constantine, to which period most writers have been in the habit of tracing the use of the cross, writes:- It every commencement of business, whenever we go in or come out of any place, when we dress for a journey, when we wo into a bath, when we go to meat, when lights are lorought 
in, when we lie down or sit down, and whatever business we have, we make on our foreheads the sign of the cross.' And Chrysostom, in $35^{\circ}$, says: 'In the private house, in the public market-place, in the desert, on the highway, on mountains, in forests, on hills, on the sea, in ships, on islands," "\&c. This last quotation is extremely suggestive of the great variety of places where crosses are found. In a future chapter we shall dwell more particularly on the versatility of design that has been expended on them, and our own inferiority in ingenuity and resource to the mediaval architects. Nothing illustrates this more forcibly than the obvious incompetence of the profession to deal with new materials, for example, plate-glass, where no precedent has been furnished-what would an architect of the fifteenth century not have given for such a splendicl material! But now whenever it is introduced in large plates, in a Gothic building, the effect is simply a kind of Alhambra appearance-not the old Alhambra, the modern one. The drawing here given illustrates a very simple object indeed, - the converting a square base into the base of an octagon shaft. These square bases are the top steps of different crosses; and by splays or brooches they become, in the next stage, octagonal shafts, having a very satisfactory and finishecl look.

To take another familiar instance. We have for more than a century been content with the modern square marble chimney-piece over a fire-grate, with a flat slab for ornaments, which is an institution peculiarly of the eighteenth and nineteenth centuries. I do not know that anything so dreary has ever been devised for any purpose whatever; nor would it be easy to invent anything else 
so bad, and yet these are being put up by hundreds daily throughout the length and breadth of the land. Perhaps a worthy rival might be found in the sash-windows which have supplanted casements. The latter when open or closed, as the case might be, broke to some extent tile

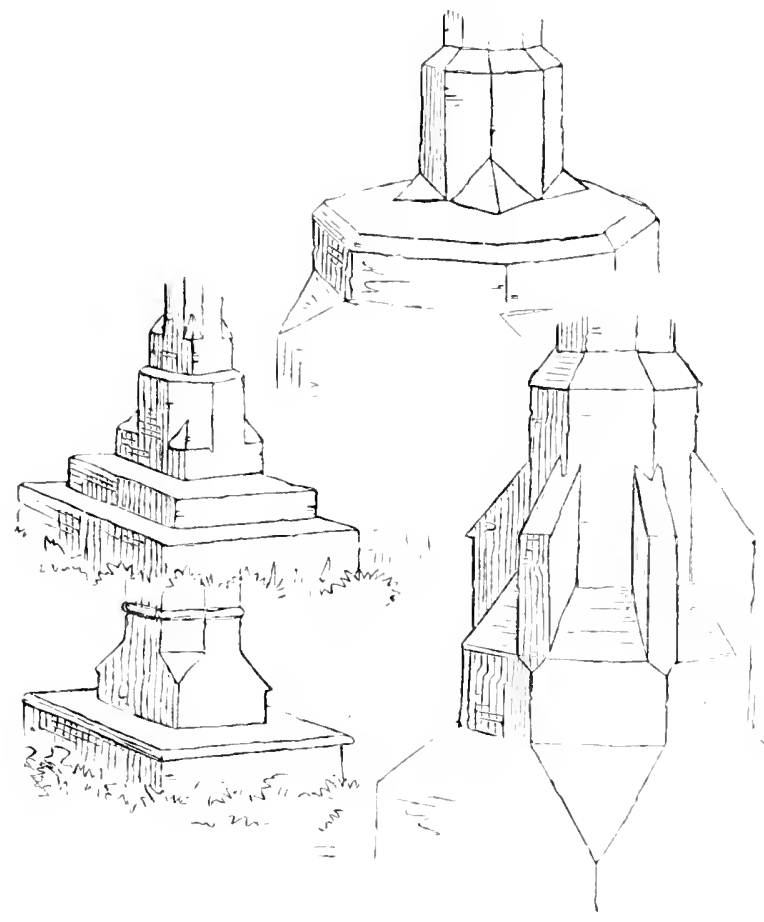

Buses in Giluziestershire and Norfolk.

monotony of a weary row of square window's, such as we see in a London street; and in a happy moment some one invented a sash-window, to give a finishing touch to the baldest kind of architecture that has ever disfigured any country. True it is they are more complicated, more expensive, and less efficient, besides offering every pos- 
sible ubstacle to cleaning. But it was a momentous question: something was left undone that could be done to ard to the ugliness of street architecture, so utility and

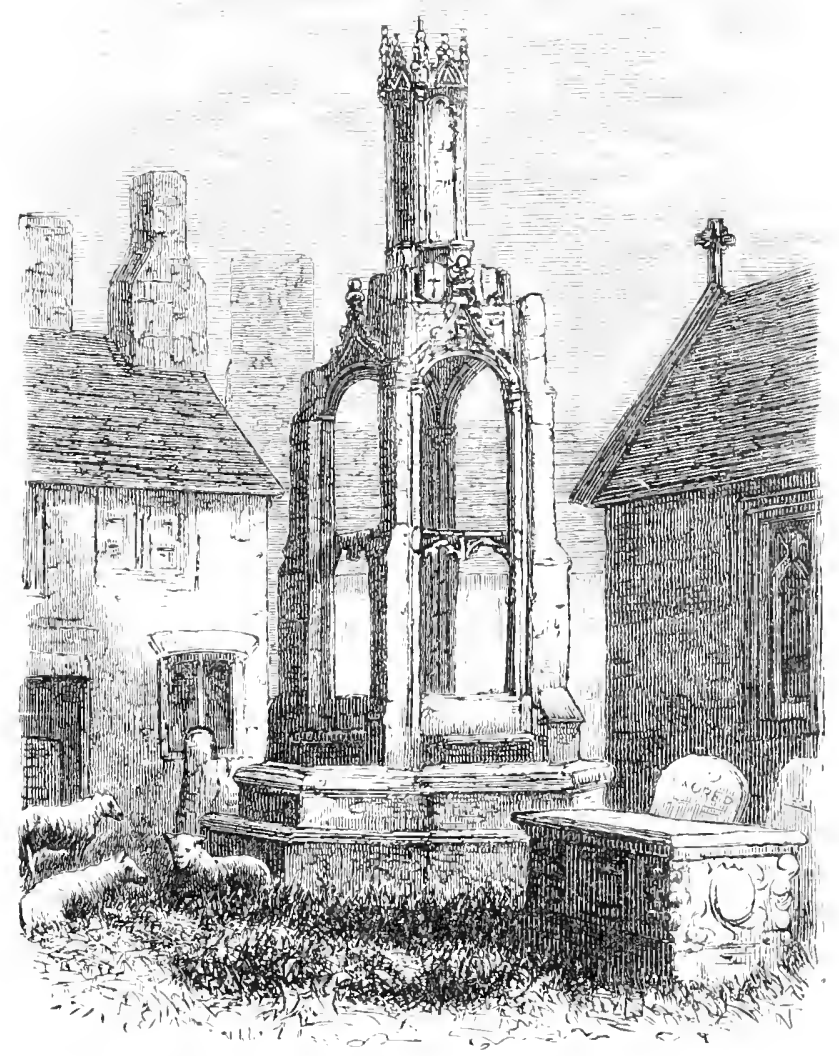

Remains of Preaching-Cross at Tron-Acton, Glowcester.

common-sense were sacrificed. These reflections naturally follow the examination of the crosses we are considering, which are not only convenient, but objects of great beauty. 
The cross at Iron-1cton, in Gloucestershire, sroms to have been designed for addressing a congregation out of doors in summer weather; the engraving can give only a faint iclea of what it was originally. The stone of which it is made is rery hard, and the carrings on it are perfect; but it has been mutilated designenly. The angle-buttresses were formerly terminated by pinnacles, and over the centre was the tall cross. It has evidently been destroyed by heary missiles; there are marks on the upper part where stones have struck; but whether the remaining part was too solicl for further mischief, or whether the inhabitants of the houses on the other sille objecter to the proceedings, we are nowhere informed. There was a light octagonal shaft, in the micllle of which the base and cap are now standing; and from this sprang elegant moulded ribs, intersected by carred bosses. The work is evidently of the fifteenth century.

The preaching-cross of the Black Friars' monastery, in Hereford, somewhat resembles that of Iron-Acton; but the details of the former are richer, and the design is more elaborate. It is perhaps, at first, not obvious why the Hereford cross is more pleasing in appearance; but this arises simply from the fact of its being hexagonal instead of square. Hexagonal or octagonal structures on this scale always suit the tone and intention of Gothic architecture better than square ones. This is happily illustrated in Chester Cathedral, where the bishop's throne, which is excellent in detail, but square, is opposite the pulpit, which is octagonal, and the difference in effect is very marked. The Black Friars came to I Lereford cluring the time of sit. Thomas Chanteloup, about 1280 , and at first 
they set up a small oratory at Portfield; but on that falling into ruin, Sir John Daniel commenced another for them,

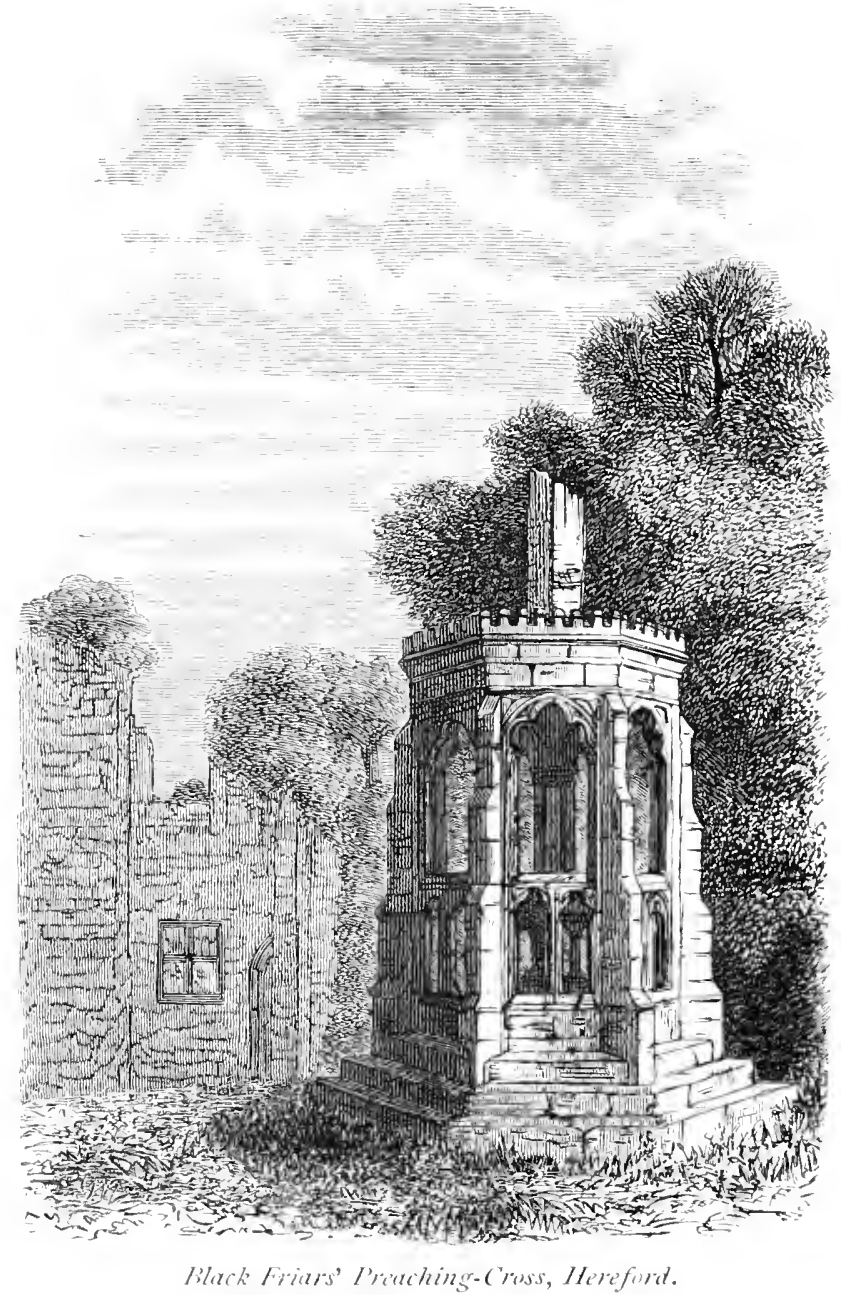

which was finished hy Edward III. Round the pulpit that is here shown were cloisters, into which the public were able to retire in wet weather without being out of 
the learing of the preachere something, it is satel, in the: style of old St. Paul's preaching-cross. In this curtosur. a great number of influential people were burierl, ats is

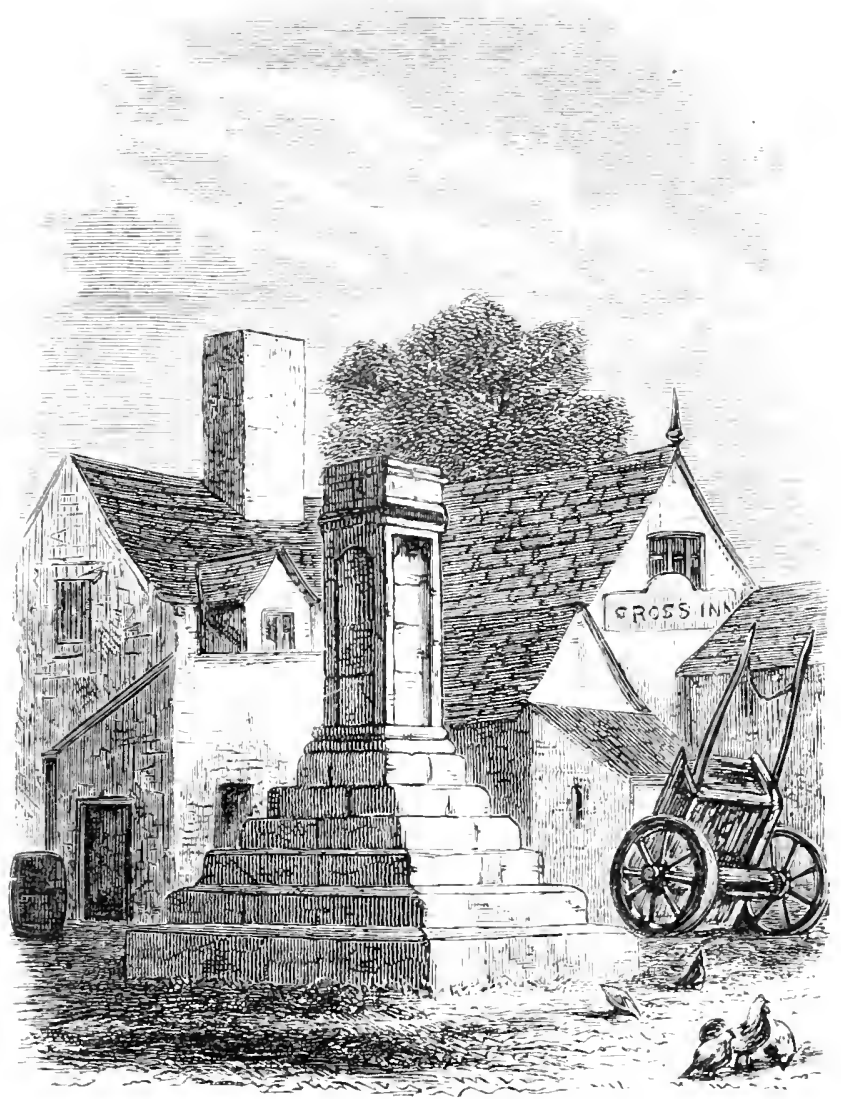

bise of High Cross at Aylburton, Gloucester.

narrated by Grose, and also by Dugdale. The monastic buildings were destroyed, and used, in the same place, for an asylum for soldiers and domestic servants, early in the seventeenth century. 
The crosses of Lydney and Aylburton, which are situated In a beautiful part of Gloucestershire, on the left bank of the severn, differ much from the preceding; and it is somewhat difficult to elassify them under any of the heads originally specified. They are approached by tall flights of steps, from which it is not improbable that an ecclesiastic may have addressed the rustics. The one at Lydney must have been a splendid structure when complete. These crosses are called by local authorities fourteenthcentury work. There is nothing in the style of architecture to indicate their age with any kind of precision, but there is no reason to suppose the date is incorrect; history is silent regarding them. Mr. Pooley, in his excellent work on the Gloucestershire crosses, points out indications of their being designed by a foreign artist-an Italian probably; and certainly the heary corners of the one at Aylburton would seem to confirm this supposition. Italian artists were not unfrequently employed; it is known that they were engaged by Edward I. on the Eleanor crosses.

Hempsted Cross, also in Gloucestershire, is situated in the pretty village of Hempsted, and within a short distance from Hempsted Court, the seat of the Lysons family, where the great work "Magna Britannia" was written, a book which for fidelity and exhaustiveness stands almost alone in antiquarian researches; even though it was a pioneer, and published nearly three-quarters of a century ago. This cross is very picturesque, standing in the middle of a quiet village of more than ordinary beauty. It lad been partially destroyed; but Mr. Lysnus, the present lord of the manor, found the pieces, and hat it restored. 


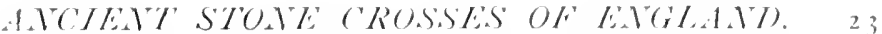

A little farther along, on the field-road to frloucester city, is another cross, differing materially from those last enu-

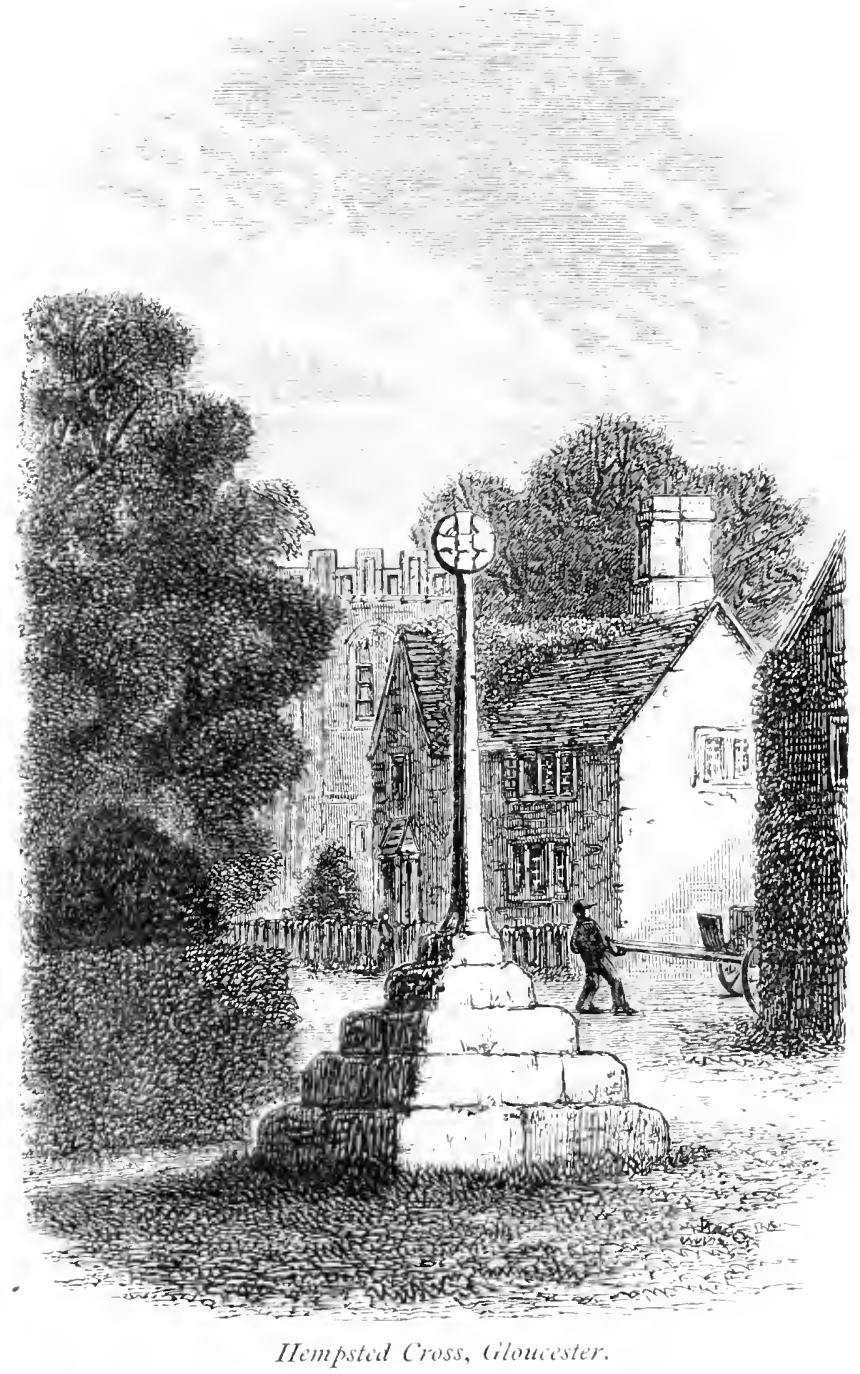

merated, and called "Our Lady" Well." It is closed in the gable on the reverse sicle of that shown, has been wall'd 
up closely in the present century, and it is commonly said to be arched with moulded ribs inside, and to have, or to have had, sume carving. 111 the ofl stone-work is singularly sharp and cloar in this district: it was solt when worked originally, and became inclurated after a compara-

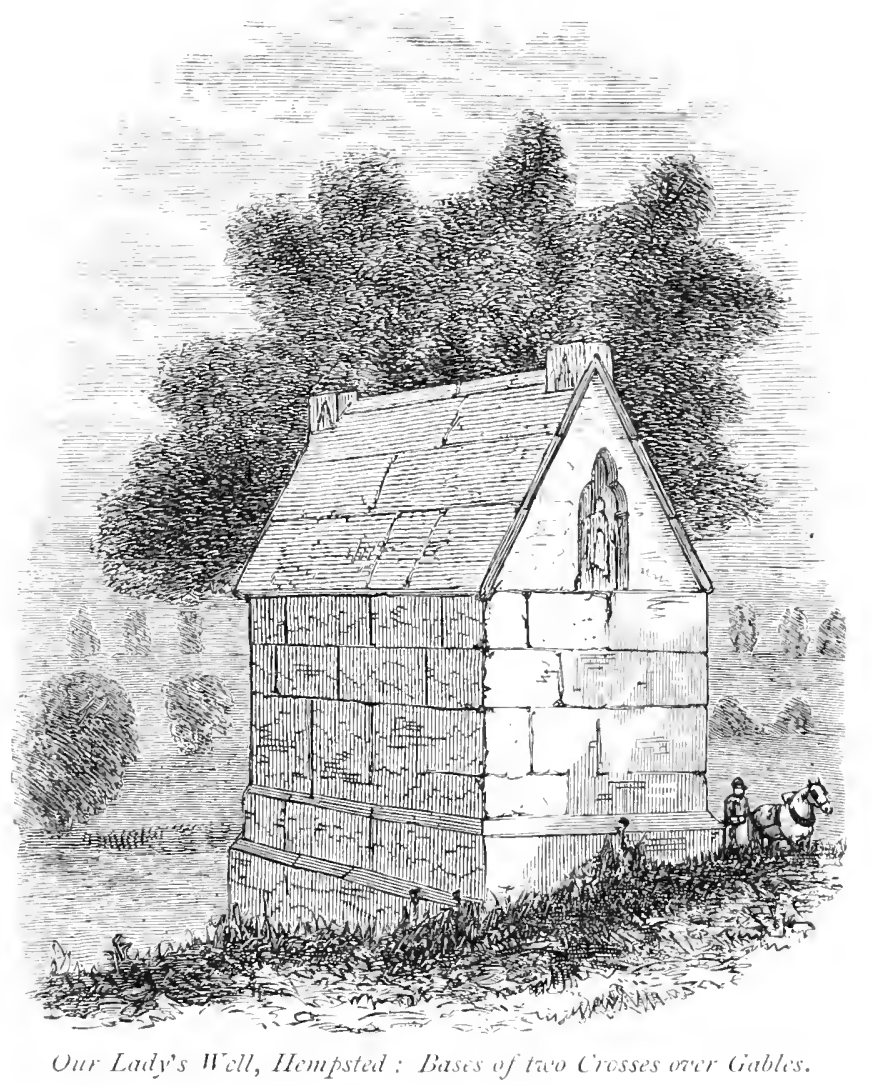

tively short exposure to the weather; and, like other stone of a similar kind, when once the face is chipped away it never forms again.

With the exception of the last cross named, all those 
treated in this chapter might be called preathing-crustes. It is often matter of conjecture why they shoukt has. been placed in such unlikely spots; a few word of explanation will suffice, beyond those alrealy given.

About one hunched and fifty yoars after the Compluest lived and flourished st. Francis, who, at the age of thirtyseven, enjoyed the title of "Seraphie Father." II. Wats the son of a wealtny merchant; but, after a fit of sickness, disinherited himself, and set to work to establish a $110 \mathrm{~W}$ order. He wore a grey serge coat, and soon was at the head of a chapter of five thousand friars, who habited themselves like him, and were called "Grey Friars." About the same time another zealous reformer, Dominic de Guzman, founded another order of friars, who dressed in black and wore a white rochet. The latter monks were the first to arrive in England, with high testimonials from the Pope; and great was the sensation they caused. They came on foot, the humility of their rule forbidding them to mount horses. They professed to want not silver, nor gold, nor lands, but felt they had a necessity laid upon them to preach the Grospel to the poor. These Black Friars, also called Dominicans, soon established a splendid monastery in London, and had a bridge over the Thames, where the present one bearing their name stands. Both these orders were called Mendicants, and even a slight acquaintance with the various brotherhoods would be useful in examining the present remains of monasteries or crosses, or indeed of mediæval architecture generally.

The Cistercians came into England in 1128, from Aumone Abbey, in Normandy, the Bishops of Winchester establishing them in the Abbey of Waverley. They might 
be called a sect of the Benedictines, and were equally remarkable for the strictness of their lives. What this strictness was, we are not at a loss to gather from the recoruls of many Cistercian monasteries: they ate neither flesh nor fowl, unless given them in alms; and built their religious houses at a given distance from each other, always selecting some secluded place. Their text was that "the wilderness and the solitary place should be glad;" and the houses of the Cistercians well carried out their text. Fountains, Furness, and Valle Crucis Abbeys, and eight hundred other buildings, were the astonishing results of their labours, of which eighty-five were in England and Vales. They went about, in the first instance, carrying preaching-stands, as the Wesleyans do now in some country places; but soon established preaching-crosses as a more convenient and dignified way of addressing the people. The difficulty of finding any historical record of so many crosses arises from the fact that they were built out of the rapidly growing wealth of the orders, and were barely recorded even at the time they were erected.

There were many other orders, besides those mentioned, who were equally strict in their way of life. WVell would it have been with them, and perhaps the generations after them, had they adhered to their asceticism; but unhappily increasing. wealth brought increasing temptations to luxury, and the profusion of their households became a by-word. Parochial clergymen invented caricatures of them, which were even incorporated in carvings in parish churches, in sometimes nameless derices, giving accidentally a cue to some modern architects to copy in their ignorance designs that have lnst their mraning. 
So strict at one time was the law of the menolicant orders, that they never spoke except in preaching from at high cross; and only mate signs, after their discourse, for what they wanted. Ilow they fell away from their high stantarl is no part of the present work to record; lut the Royal Commission found that in Furness Abber, Roserus Pele, the Abbot, had one more wife than would be allowed to even a layman, and two more than an ecclesiastic ought to have, as the chronicler relates ; and others were enumerated who had similarly relaxed the rules. It is only fair to the Cistercians to ald that they covered the country with builelings that have no rivals in any country for architectural skill and beaty ; indeed, we may generally refer any large building of more than ordinary beauty to the Cistercian order. 
III.

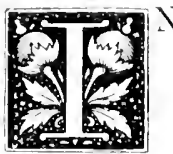

writing a brief treatise on the "crosses" of England, it has been found almost necessary to adapt the subject to a series of essays, as beyond a certain limit classification would become difficult; though, indeed, the next chapter, on the Queen Eleanor Crosses, will deal entirely with one portion of the subject. Could road-side crosses liave remained to the present day, they would have been cherished objects in almost every village of England; but to blame wholesale the spirit that led to their destruction, would be not to make sufficient allowance for the terrible times from which all Europe was scarcely emerging. After the suppression of the religious houses by llenry VIII. there had been a vigorous attempt to re-establish the Roman Catholic religion in England, and the Inquisition was strengthened by royal favour. So far, however, was the Reformed religion from being put down, that it seemed to flourish in spite of it, and France, through four stormy reigns and the invasion of many foreign armies, was shaken to its very centre. Spain was at this time, perhaps, the most powerful country on the Continent of Europe, and resolved to put down the Reformation, even in its most incipient aspects, and that by the Inquisition. llere it may be well to con- 
sider what the Inquisition was. There was nothing new in the idea of an inquisition; it was established in linance, Italy, Fermany, and Portugal, and also in England. We all remember how, in "Marmion"-

" that blind old abbot rose

To speak the chapter's doom ;"

and after hearing all that could be said, his-

" doom was given,

Raising his sightless balls to heaven :-

'Sister, let thy sonows cease;

Sinful brother, part in peace!, ,

And then the executions took place, in the picturesque language of Scott, while the abbot and chapter hurried up) the winding stair. " But the Spanish Inquisition," according to Schiller, "came from the west of Europe, and was of a different origin and form; the last Moorish throne in Granada had fallen in the fifteenth century, but the Gospel was still new, and in the confused nature of heterogeneous laws the religions had become mixed. It is true the sword of persecution had driven many thousand families to Africa, but a far larger portion, detained by the love of climate and home, purchased remission from this clreadful necessity by a show of conversion." And indeed, while the Mohammedan could offer up his prayers in private towards Mecca, and the Jew could still pray with his face towards Jerusalem, Granada was not subdued, and Jews and Moslems were lost to the throne of Rome. So now it was decicled to extirpate the roots of their creeds, their manners, and their language; and the Inquisition, called the "Spanish" Inquisition, was established. It has received this name in order to distinguish it from all other inquisi- 
tions by its wickedness and cruelty ; indeed, we may search all the annals of history for its prototype, and happily we shall search in rain. The moment a suspected party, in fact, any one that even doubted the impeccability of the Pope, was pointed out, his fate was sealed: he was led in mock procession under the bright skies of Spain; bells were jangled out of time and tune; priests sang a solemn hymn; and with yellow restments, painted all over with black devils, with a gagged mouth, without sometimes knowing the name of his accuser, or even his particular crime, he was led to his execution. This Inquisition soon spread through Portugal, Italy, Germany, and France, and even Inclia was not long free from its powerful arm. England, of course, was particularly obnoxious to it, and in order to its establishment on these uncongenial shores, the Spanish Armada was equipped and sent. Indeed, when the order went abroad from parliament for the destruction of crosses as pertaining to the Romish Church, it should be remembered that men were still living who had known galley after galley go to the bottom of the English Channel with its racks and screws on board. Of course all this cannot excuse the destruction of crosses by the Puritans; who, indeed, in their turn, were equally illogical, and in many important things as bigoted as the parties they oppressed.

The "Percy Ballads" contain an excellent satire upon the destruction of Charing Cross. The edition published in 179t says, in the introduction to this ballad, that Charing Cross "was one of those beautiful obelisks erected by Ehward I., who built such a one wherever the hearse of his beloved Eleanor rested on its way from Lincolnshire 
to Westminster. But neither its ornamental situation, the beauty of its structure, nor the noble design of its crection, could preserve it from the merciless zeal of the time." And then it proceeds to show how even the quict peopl. of those times looked upon its senseless destruction :-

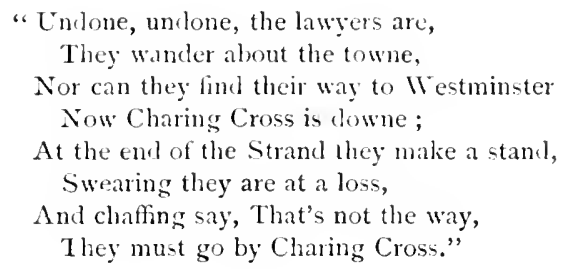

From another part of this clever satire there seems to have been an inscription on this cross; for the writer protests that it could not have had any treasonable designs, as it never was heard to speak one word against the parliament. Hesays-

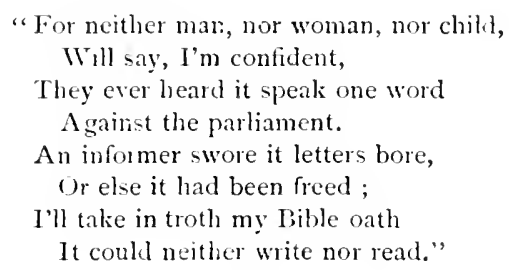

Lydney Cross, in Gloucestershire, is situated not far from Aylburton, already mentioned, which it must have somewhat resembled, though it stands on a higher flight of steps, and is more imposingly situated at the end of the road leading into the village. What the original form may have been it is not easy now to determine, but the base seems well adapted for the support of a good cross; it was probably brooched into an octagon on the next stage, and finished with tabernacle-work. Lydney was granted to 
Sir IVilliam IVintour, who did such good service in the time of the Armada; he built a house there, which was destroyed during the ciril wars, when the cross was dis-

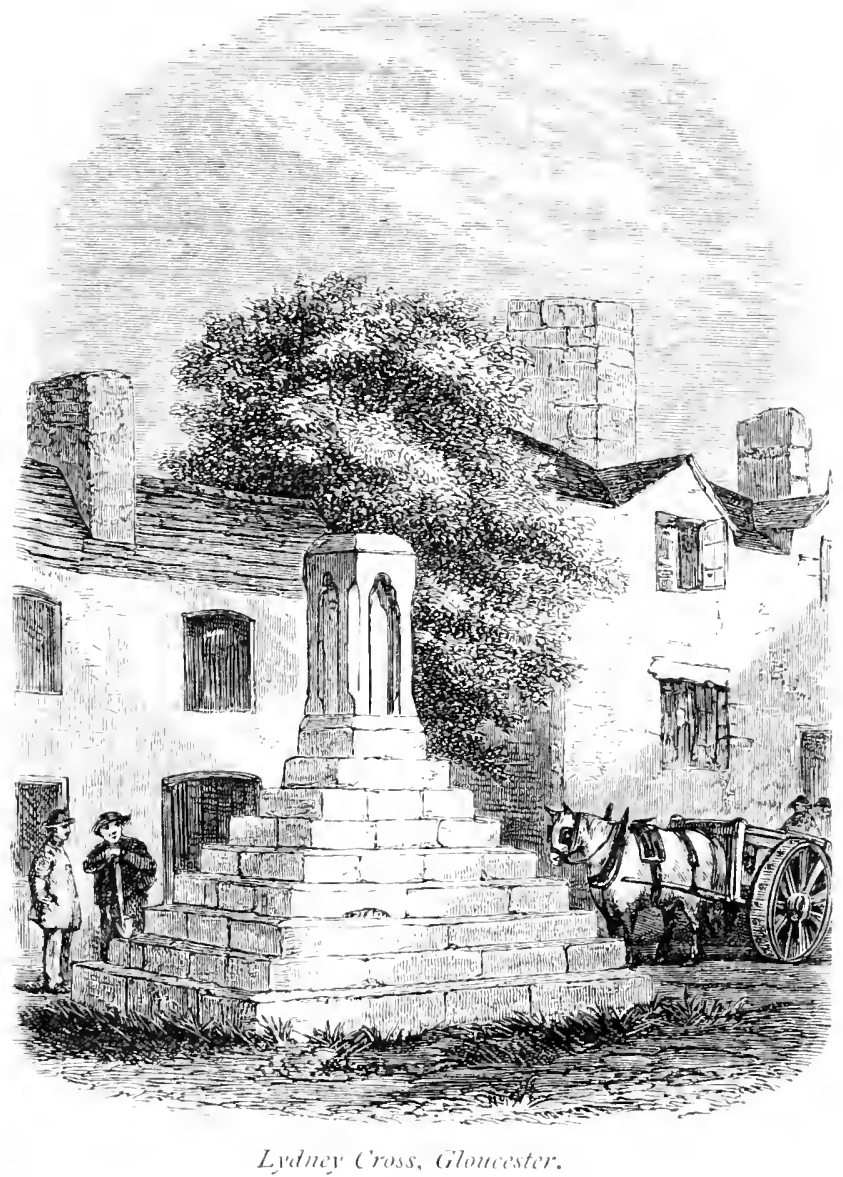

mantled. The manor was afterwards purchased by the liathurst family, who built lydney IIouse in one of the most beautiful parks in Great Britain.

Bisley Cross, also in Gloucestershire, is unlike any in 
England. It is called by so careful a writrer as britton, a preaching-cross; but this must be a mistake. Incleerl, it is not certain, from his notice of it, that he hat seren it : he appears rather to mention it as a specimen of crosses in

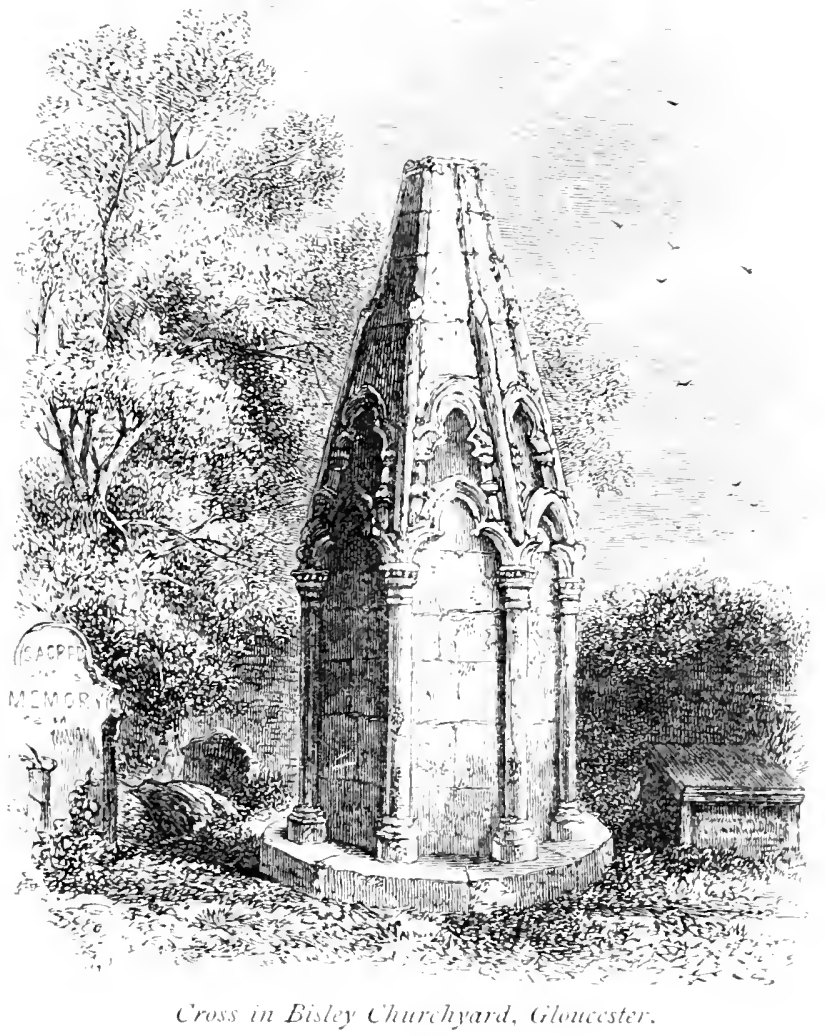

general, which was a subject he promised to take up whin time permitted-which, alas! it never did. liskley Cross has all the appearance of having been ereeted orer a well in the churchyard; but there is no trace of a spring nuw. 
Perhaps, however, the water may have dried up, as is not uncommonly the case in that stratum; this is the more probable, as one of the late Mr. Lysons' plates shows

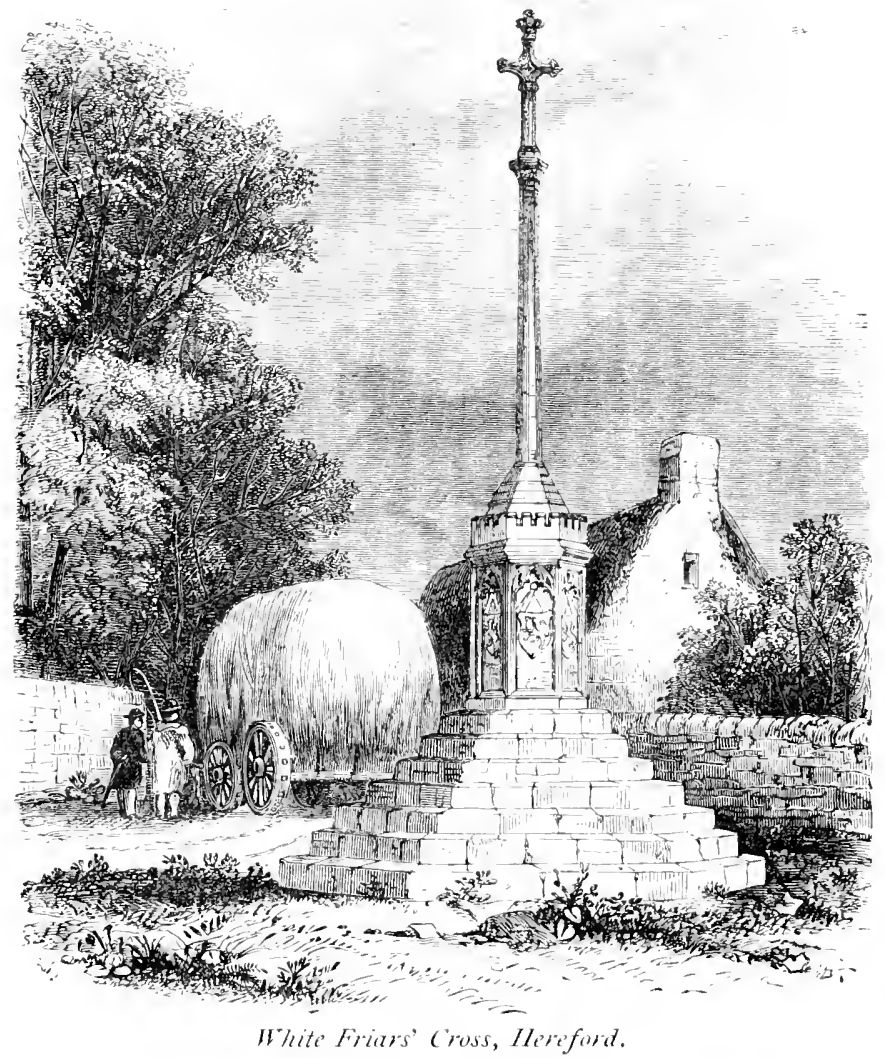

the cross crowned by a sort of font. Bisley is one of the most ancient crosses-excepting those at Sandbach-of which we shall have occasion to speak. It must have been built, accorling to its mouldings and its general 
appearance, about the year 1170 . It stands on a circular basement, upon which are six upright shafts forming a hexagon; these again support six cusped arches with Early English mouldings, and are terminated by bold Early English heads; fillets run up each angle and stop very singularly in a bevel, about half-way up; this hexagon supports again six smaller arches with very deep mouldings. The general appearance of the work resembles Peterborough and other Early Pointed specimens.

White Friars' Cross, near ILereford, stands about a mile from the city; the upper part is new, though built probably in the style of the old. There was formerly a market held here. The cross was built by Bishop Charlton at the time of a great plague in Hereford; but there are no traces left of the plague-stone, which contained the hollow for vinegar, in which the money was placed. This is a very valuable and beautiful specimen of a roadside cross, and must have resembled Lydney when the latter was perfect, only that it is richer and more elegant in workmanship.

Clearwell Cross, in Gloucestershire, is generally attributed to the fourteenth century; it is on a square base, which rests on large square steps, as shown in the woodcut, and is a very characteristic specimen of the ordinary roadside cross of that district: in other parts of England different forms prevailed, and the light tabernacle work is common. The general form of these crosses may be described as tall shafts (monoliths) resting on a base like that at Lydney, Clearwell, or Hereford, generally square, but occasionally hexagonal, and diminished by brooches: on this shaft was carved the cross, in many instances, but in others a wrought-iron cross was substituted, which was 
fixed on iron hooks driven into the monolith; some of these hooks still remain.

Tottenham Cross, again, is a type of a totally different kind, and is here introduced as a contrast. The present

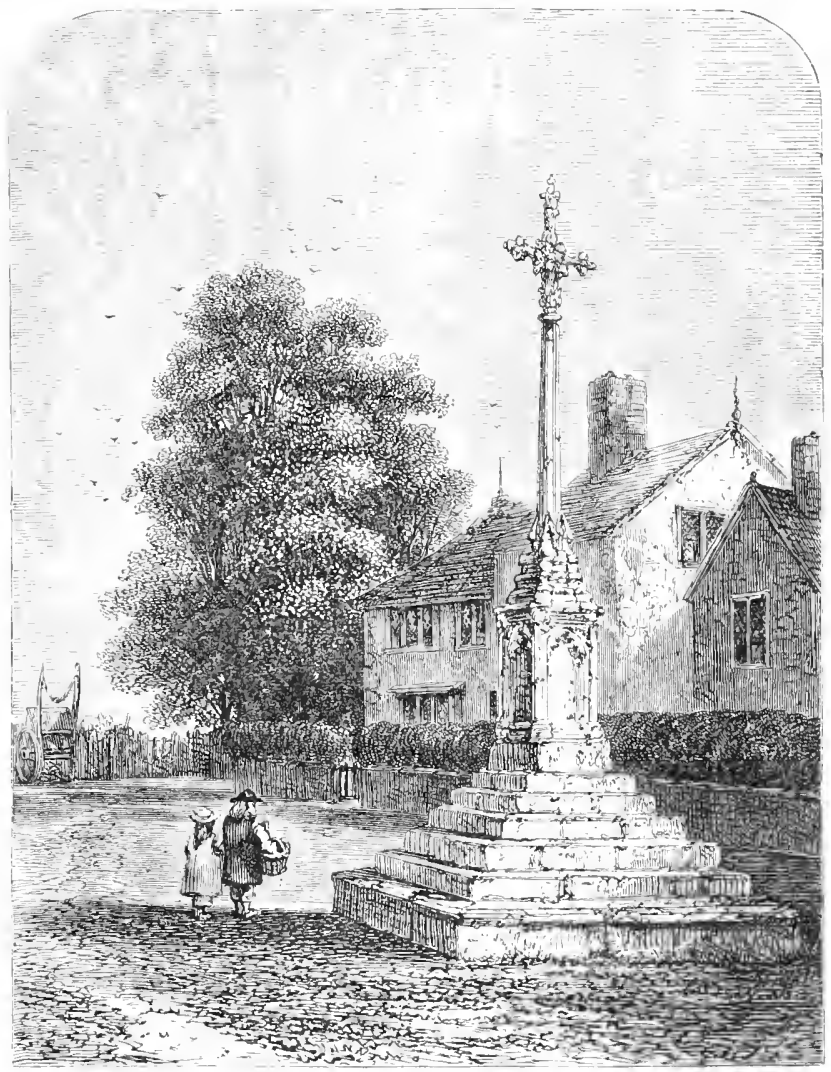

Clanarell Cross, Glowestorshire.

structure is comparatively modern-or at least it is the old cross cased round. The ancient cross is familiar to us from old-fashioned prints, in which the earlier Georgian dresses appear, and also mail-coaches; it belongs to the 
type of solid crosses, like miniature spires. These seem to prevail more in the eastern counties, and of them the Eleanor examples are pre-eminent among all others in the kingdom for their grace and beauty: Greatly inferior as this cross is in every way to the Eleanor crosses, it is a pleasant object by the roadside.

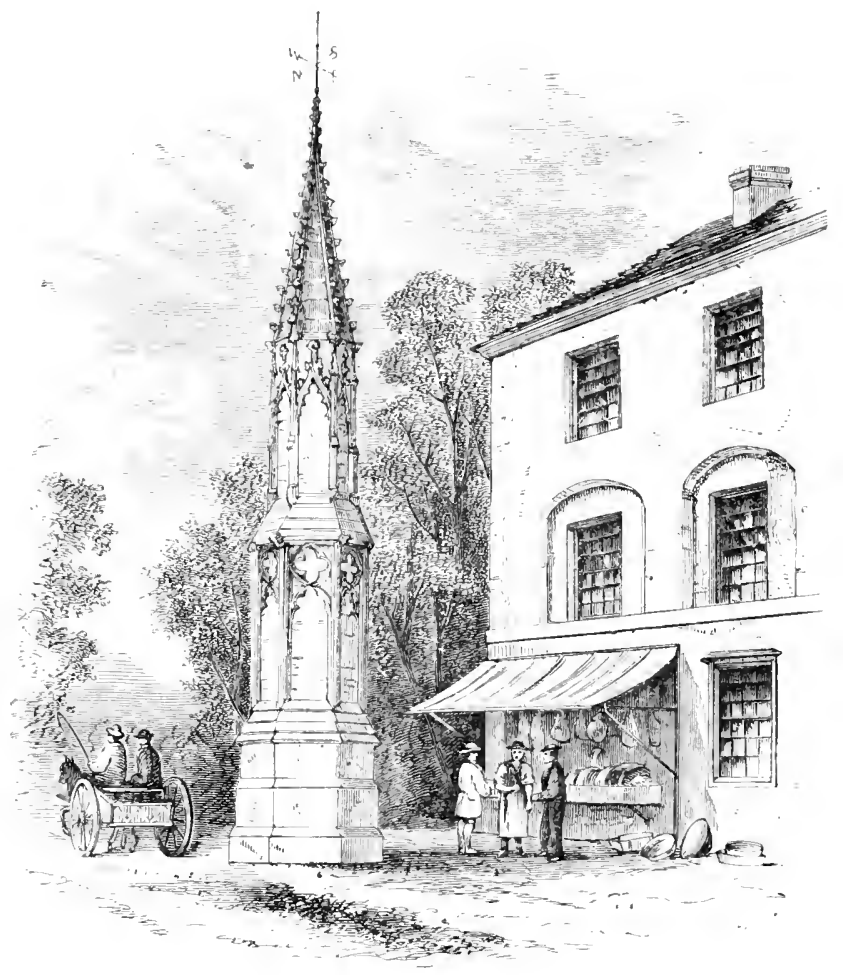

Tistenhan cross.

As we have before remarked, there are other forms of crosses peculiar to certain localities, and, as a contrast to each of the last-named, is the cross with the tabernaclehead, like the "Chester Cross," engrared on page 7-not 
that even these are confined to any strictly laid-clown limits; thus there is one at St. Donato, Cornwall, one at Cricklade, Wiltshire, one at Henley-in-Arclen, Warwickshire, and there are more at other places. It is a pleasing fact to be able to announce that a beautiful tabernacle-head to a cross has been discorered in the middle of Cheshire.

The last cross we shall notice in this chapter is a very curious one at Oakham. Britton mentions four oak marketcrosses as standing at the beginning of this century; and doubtless in counties where oak-trees were plentiful these crosses were once numerous: but to this one at Oakham he has not alluded. It is an interesting and extremely picturesque object, standing on eight square blocks of stone, on which are as many upright oak posts; a beam goes from each and rests on the head of its neighbour, being supported by small struts; and in the middle is a very solid pier, with two steps or seats for the market-people. There is another oak market-cross in the same town, but it is square; and, though apparently of the same age, is far inferior in picturesqueness to the one we engrave. Oakham is an exceedingly interesting county town, and is not visited so much as it deserves. It formerly belonged to the Earls Ferrar, who exacted tribute from all barons passing through; in later times this was often commuted into the payment of a horseshoe (the arms of the family); some of these are still loung up in the Town Hall, and are of enormous size. The Town Hall was formerly a part of the family mansion. If this cross be considered only a variety of such as Chichester and Malmesbury, we shall then have taken a brief survey of all kincls of crosses in England. 
Inscriptions on crosste were formerly common, and alluded either to the piety of the founder, for whom prayers were invoked, or rominded passers-by of their duty. The old cross at II avertres rillage, near Liverponl,

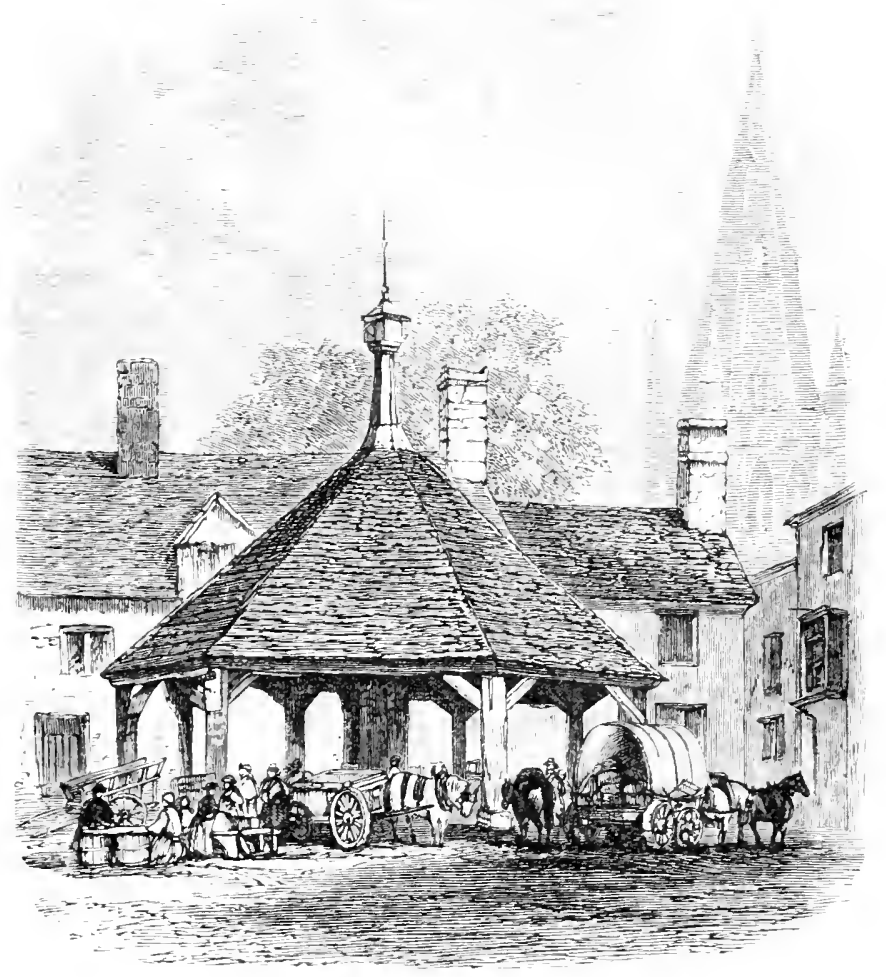

Uakham Market-cross.

is pulled down, but the well and the inseription remain :-

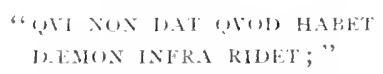

which has been translated in Bain's " Jancashire" into the: 
following almost literal couplet :-

"He who does not here bestow,

The devil lauglus at him below ;"

and, incleed, other remains show almost equally broad hints for the contributions of the faithful. The Eleanor crosses, however, which will form the subject of our next chapter, were only put up for the prayers of passers-by for the rest of the soul of the queen.

Sir Walter Scott, in his last canto of "Marmion," thus alludes to the inscription on the cross and well where the Lady Clare went for water to bathe the head of Marmion after his wound :-

"Bebold her mark

A little fountain cell,

Where water, clear as diamond spark,

In a stone basin fell.

Above, some halfwom letters say.

Prink, ataly pilgrim, arink: and pren

For the kind stul of Suld Grey,

thwe tuilt thin cress and aill." 
IV.

MONG all the memorial crosses in Europe, those of Queen Eleanor stand alone. Their beauty of proportion, their variety of design, the ideas which they have suggested to modern architects, and the touching story of their erection, give them undisputed pre-eminence.

Queen Eleanor was espoused to Edward I. in 1255, in the tenth year of her age, he himself being but five years oller. This espousal took place cluring the risit of the prince to Alfonso X., King of Castile. She remained in France till her twenticth year, and then went orer to England to join Prince Edward, living principally at Windsor. Here their two eldest sons were born, who gave great promise from their intelligence and beauty. Another son was also born before they left on their ever-memorable expedition to the Holy Land; on their return they learned, while staying with Charles of Anjou, that their two eldest sons were dead. Another was shortly after born, and named Alfonso, after Eleanor's brother; he is said to have been more promising even than the others, but he also died very early. They had in all fifteen children, and of these six survived. Queen Eleanor accompanied her husband in all his expeditions 
and wars-the Holy Land, Wales, and Sicotand; it was her tact and exceeding amiability that assisted him to pacify the malcontent Welshmen. Rhuddlan Castle and Caernaron were alternately her residences, and Conway at a somewhat more recent clate.

No one can be surprised, after a brief perusal of the reign of Edward, that his devotion to his queen was so great. She entererl into all his schemes, was beloved by his subjects, in whose welfare she always took an interest, and her sweet beauty is immortalised by Pietro Cavallini in the well-known monument at Westminster.

Queen Eleanor died at Harby, or IIardeby, in Nottinghamshire, while travelling northward to join her husband in his Scottish wars. She was seized with a clangerous autumnal fever, and though Edward, immediately on hearing of it, turned southward, he never saw her again alive. Nothing more singularly illustrates the looseness with which authorities are quoted, than the difficulty that has been experienced in arriving at the actual route the body of Queen Eleanor was taken in its last journey. She has often been said to have died near Bolingbroke, in Lincolnshire, but many circumstances point to Hardeby as being the actual place. She died at the house of a gentleman named Richard Weston, but every trace of the house and the family has now disappeared. The queen may probably have been on her roal to Broadholme Priory, only a few miles distant.

Iler illness seems to have been rather lingering, for we read that on the 18 th of October, or six weeks before her death, a mark $(13 s$. 4 . ) Was paid to Ilenry of Montpellier for syrups and other medicines for the use of the queen; 
rither a considerable sum in those days, though there is much difficulty in arriving at the value of money at that period; at least, the common method of computing it as worth ten or twenty times as much then as it is now both of which estimates are maintained, is exceedingly vague. Thus it is said that William of Wykeham only received 1s. per clay for his work at Windsor Castle, with an extra shilling per diem for any other work he was employed on for the king. This, however, was to inclucle all travelling expenses; although, probably, he had never far to go. There is a singular calculation that for long journeys, such as from London to Carlisle, the nominal sum, if luggrage were included, would fully equal that paid at the present day, which alone will give us an insight into the enormous cost of travelling in ancient times, and perhaps account for country towns, even up to the present day, bearing traces of having been centres of social "seasons" for families of rank. We must not, therefore, infer that $13 s$. $4 d$. Was an exorbitant bill, or that it indicated any very'serious overcharge on the part of the Lincoln apothecary, for we cannot tell what he had to pay for the medicines. The queen was attended by her own physician, who bore the Spanish name of Leopardo, and also by a brother-doctor, who held a high position in the court of the King of Aragon.

There are those who maintain that King Edward was simply on a hunting expedition, and not proceeding to the Scottish wars; of this they say that the meeting of the parliament at Clipston, where he had a mansion, and where his signature appears to rlocuments, is ample evidence. In support of this riew, he is traced from Geddington to 
Macclesfield, in Cheshire-which, indeed, lies near Delemere Forest, and is still crown property : but the probability is that the documents alluded to were signed some days, or even weeks, after they were executed.

Queen Eleanor died on the 28th of Norember, 1291. A cross was erected at every resting-place of her funeral procession on its way to Westminster. There was nothing particularly new in the idea; it was only an extension of the lich-gate system, for a corpse always rested uncler a "lich," of which there are many left in every county in England; and, indeed, these resting-places are quite analogous to the Eleanor crosses. On the road from Paris to St. Denis, the last resting-place of so many kings of France, crosses were erected at almost every few hundred yards-a1l, however, to be swept away at the Revolution ; incleed, by a decree of 1793 , more than fifty tombs were destroyed at the grand Abbey of St. Denis.

The places where Queen Eleanor's body remained for the night have been numbered at fifteen, but probably only twelve of the so-called Eleanor crosses were erected. The distance from Hardeby to Westminster, by the old roads, was one hundred and fifty-nine miles; and if thirteen and a half miles were accomplished each day by the melancholy procession, that would be a consicterable journey; the season was winter, and the roads in the east of England were very bad. We believe, after much research, that the sites of the crosses were Lincoln, Grantham, Stamford, Geddington, Northampton, Stony-Stratford, Woburn, Dunstable, St. Albans, Waltham, West Cheap, and Charing. .

The queen's heart was deposited in the church of the Friars l'reedicants in L.ondon, and the bowels in the chapel 
of the Virgin in Lincoln Minster, where there is also at statue to her, and another to her husband, both of singrular beauty and dignity.

The funeral procession set out on the th of December, and arrived at the end of its memorable stages on the $i$ th. After leaving Stamford, the ordinary route was abandoned, to enable some of the religious houses to be visited; and it seems that, after leaving St. Albans, the king hastener on to London in person, and met the procession on its entrance into the city.

All the Eleanor crosses have disappeared except those of Geddington, Northampton, and Waltham; these three are fortunately in a state of good preservation. Their variety of design suggests that they are not the work of the same hand. Geddington cross is unlike any English Gothic architecture; indeed, it has so much the appearance of the architecture of Spain at that period, as to make it probable that it was the work of one of the queen's own countrymen. It is triangular in plan, and, as will be noticed, the fronts of the figures face a mullion, unlike the other crosses; suggesting. incleed, rather a caged look. But this is not the most awkward part of the design, for it will be seen that, if viewed from an angle, the whole structure is of necessity off the centre. The diaper patterns, which are illustrated in the fifth edition of Rickman, are eight in number; as will be seen, they cover the whole of the lower stage of the cross. They are exceedingly well engraved in Rickman's work (apparently by the late $\mathrm{O}$. Jewitt), and are in themselves of great beauty. This cross is erected over a spring of clear water, which never runs dry.

That Geddington should have been chosen as a resting- 
place is not to be wondered at, as it is certain that a considerable royal palace stood there. Though this beautiful Northamptonshire village is now but little known, and

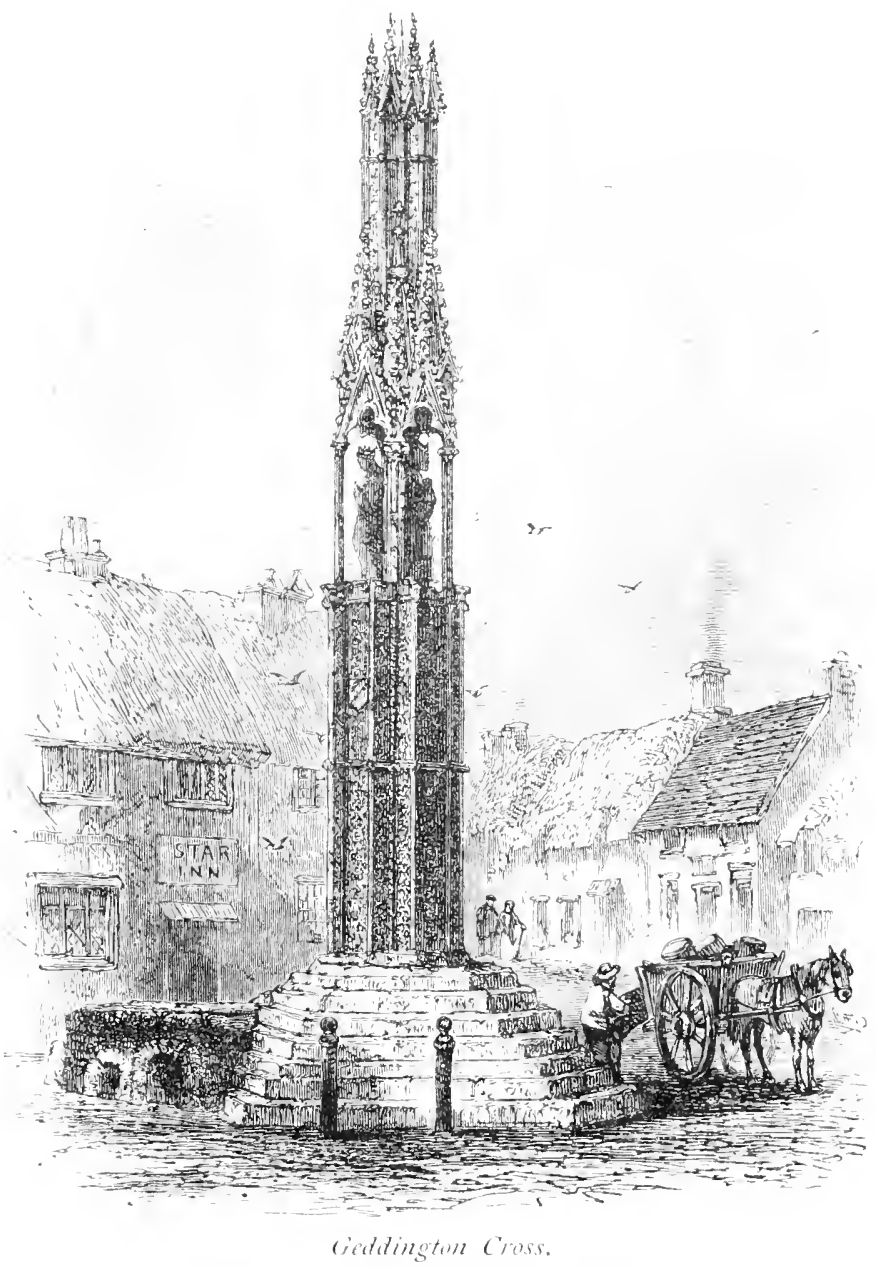

even that little chiefly from its cross, parliaments have discussed and passed weighty matters there in ancient times. Henry II. here decided on the expedition to the 
Holy land, and many articles concerning the voyage wore concluded. Stowe says, "the whole realme was troubled with taxes" in consequence-all decided on at this little hamlet. John also held parliaments here, and clated many charters from it. Every trace of this palace has passed away, though there is a field on which it stood, which still bears the name of the IIall Close. The little inn, the

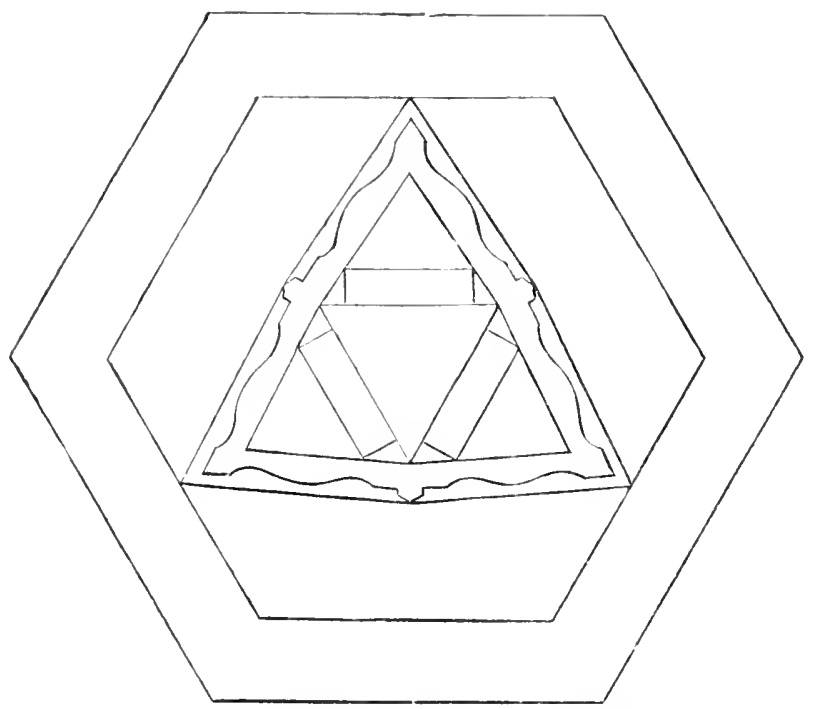

Plan of Goddington Cross, Northamptom.

Star, which is close by, bears traces inside of having been part of a "consilerable house of great antiquity." The two posts shown in the woodcut are part of the village stocks. From an old print, published in 1788 , it seems that the third story of the cross was utilised for a sun-dial.

From Geddington the cortége went to Northampton, which it reached on the $9^{\text {th }}$ of December, the distance of this stage being about nineteen miles; the road is exceed- 
ingly beautiful, and passes by the seats of the Duke of 3iuccleuch and Lord Overstone. Northampton Cross, unlike Geddington, is octagonal in form, and is in an

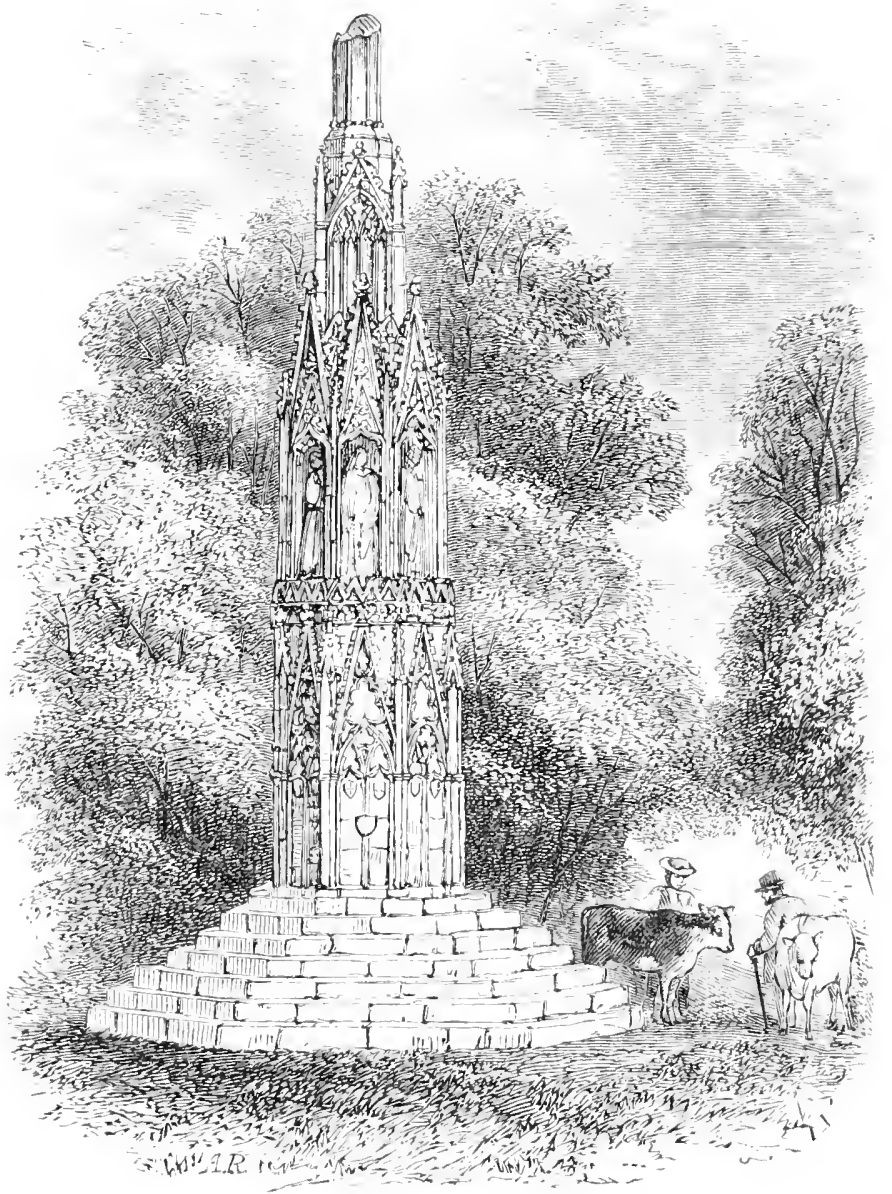

Northampton Cross.

exceedingly fine state of preservation; it stands about a mile from the town, on the London ruat, in a large recess in the park wall of Delapre Abbey, the seat of the Bourerie 
family. Northampton has many ancient buildings, edifices which were two hundred years old even when Queen Eleanor's remains rested there; it must have been a place of comparatively much greater importance in those days than it is now. This cross has been perhaps less often copied than Waltham, but it is not inferior to it in beauty of design. The Martyrs' Memorial at Oxford, designed by Sir G. G. Scott, is a combination of the two. The female

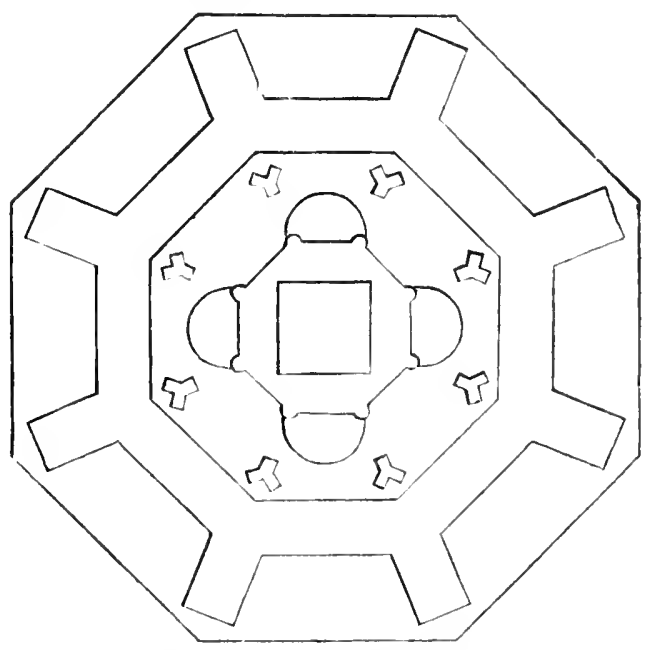

Plan of Aorthampton Cross.

figures are exceedingly graceful and light. Queen Eleanor must have been above the average height, and a wonderful example of feminine beauty. The top of this cross is broken off exactly as it is shown in the engraving; from the gencral appearance of the design the shaft probably ended in light pierced gables, with pinnacles between, and from this the cross started: happily no modern architect has been commissioned to attempt its restoration. The plan of the cross, which is here shown, is curious, and 
very ingenious, and resembles one of the snow-crystals, except that the latter are always hexagonal. The plans of the crosses of Geddington and Northampton, in their various angles, offer a contrast of design to WValtham, which is hexagonal, so that the three crosses left to us are all of different plan, and differ even as to the number of their sides. In a recent and interesting work called "ArtStudies from Nature, as applied to Design," * there are a number of snow-crystals shown; so closely do these resemble in character the plan of an Eleanor cross, that they might readily be adapted by an architect; by running up perpendiculars from their angles they would suggest new forms with unerring certainty; indeed, this idea seems to have been present to Mr. Glaisher when he wrote the article which that work contains on these snow-crystals.

From Northampton the procession went to Stony-Stratford. This is a stage of only fourteen miles, the route lying through Blisworth, Road, and Grafton Regis. Every trace of the cross has disappeared, nor can we find where it stood.

The next place on the route to London was Dunstable, which lies nineteen miles farther off; here, as in the last place, all traces are gone. Tradition yet speaks of the glory of this structure, which was built near the present Town-Hall. Camden says of it that it was a cross, or pillar, adorned with the arms of England, Castile, and Ponthieu, and bearing carved statues of the queen. The procession would thus pass by Fenny-Stratford and Wo-

* "Art-Studies from Nature, as applied to Design. For the use of Architects, Designers, and Manufacturers." Plofusely Illustrated. Virtue \& Co., Iry Lane, I'iternoster Row. 
burn, through Watling Street; but as Woburn Abbey is two or three miles off the London road, and only ten from Stratford, which they had left in the morning, it is not apparent why they should stay there for the night, especially as the abbey was deserted by the monks in 1234 , in consequence of the scanty endowments, and was not opened again till the end of the century; still, however, tradition assigns here some wayside monument to the queen. The road from Dunstable to St. Albans is only twelve miles long; it passes through Kensworth and Redburn, and lies in a very pleasant country.

The Abbey of St. Albans was of great dignity in those days, and naturally the procession would rest there before proceeding. It had entertained Henry I. and Queen Maut nearly two hundred years before, on the occasion of its consecration, keeping up festivities for eleven days. The church of that period is still standing, built of Roman hewn stones.

The last resting place of the body before entering the precincts of Jondon was Waltham. Waltham Cross is certainly one of the most precious inheritances we have from the architecture of the Niddle Ages. On an old print of this cross, fated 178 , is the following inscription:- "Waltham Cross, here represented to $y^{\text {r }}$ N.E., was one of the crosses erected by King Edward I., about $y^{\text {re }}$ year 1291, in memory of his consort, Queen Eleanor, dar. of Ferdin". 3 .. K. of Castile \& Leon, whose arms are cut on the lower part of this cross, as are those of $y^{\circ}$ Countess of Pontieu, her nother, \& also of England." In another print of apparently the same date occurs the following:- "In memory of Queen Eleanor, the beloved wife of that glorions. 
monarch, who accompanied him to the Holy Land, where her Royal Husband being stabbed with a poisoned Dagger by a Saraycen, and the rank wound jutged incurable by

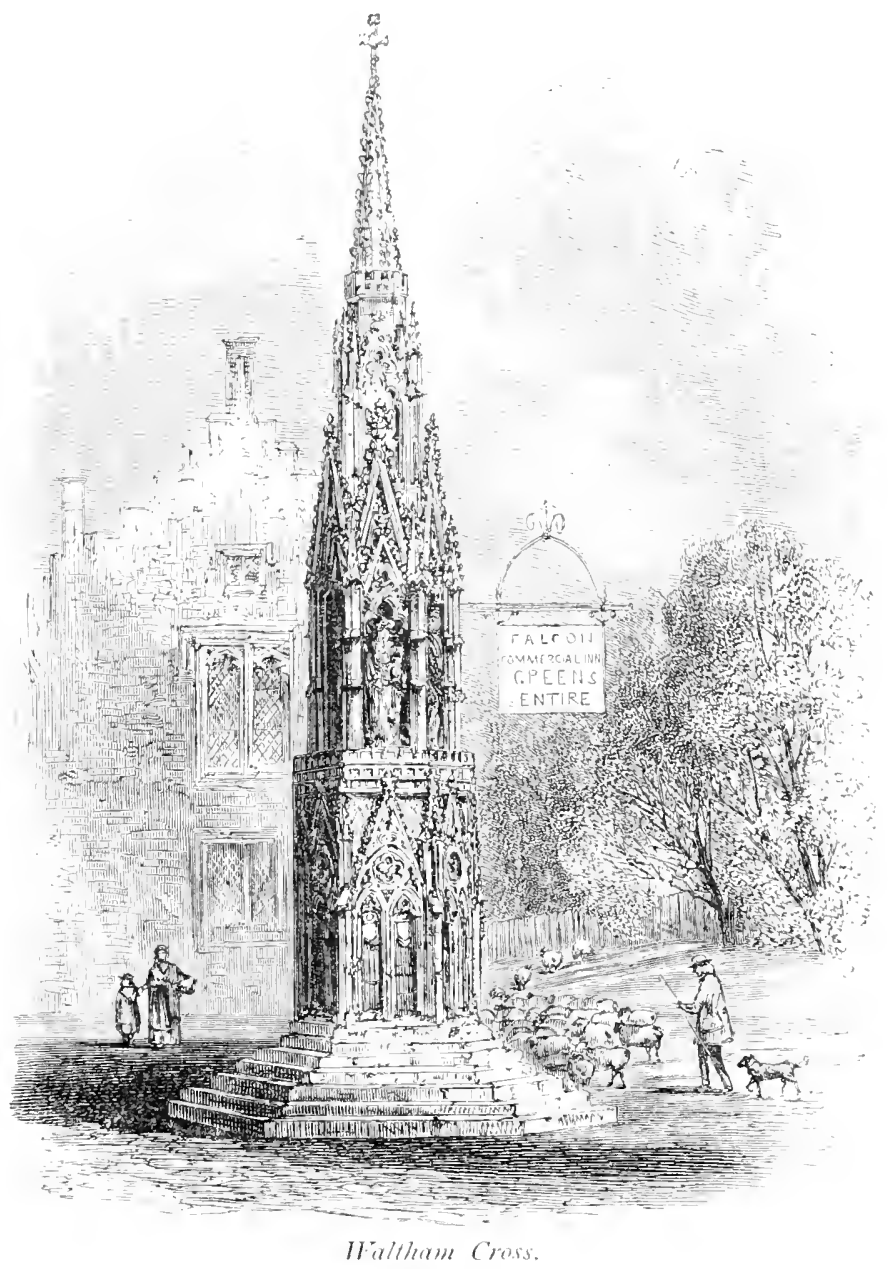

his Physicians, she, full of Inve, Care, and Affection, adventured her own life to save his, by sucking out the substance of the poison, that the wounds being closed and 
citracised, he became perfectly healed." Farther on the inscription says that roadside crosses were erected at "Lincoln, Grantham, Stamford, Gicklington, Northampton, Stony-Stratford, Dunstable (now destroyed), St. Albans, and this at Waltham, being the most curious in WVorkmanship, Tottenham \& Westminster, now called Charing Cross."

The words "now destroyed" are encouraging, for it would imply that some traces of all the crosses but that at Dunstable were to be found when this print was published. We have seen how the burying of Chester Cross saved it in the seventeenth century; in the same way a foot of earth may be hiding some of the others. "Tottenham Cross," as already mentioned, is not an Eleanor cross.

Waltham Cross has been more often copied than any one remaining in England; it has been excellently imitated on a much larger scale in the Westminster Crimean Cross, near the Abbey: perhaps the only fault being the comparative weakness of the lower story: but it is the best modern cross in England. From Waltham to London, through Tottenham, the road is well known.

Cheapside Cross was demolished by order of Parliament in $16+3$, but this was not the original one erected by Edward in memory of his queen, which fell into decay, and was supplanted by another in $1+86$. This again crumbled, and was rebuilt in 1600 , in the Elizabethan style. There is a well-known print of the demolishing of Cheapside Cross, published not long after the event, and the circumstance was satirised in the "Percy Reliques."

Charing was the last stage where the body rested. There is a very fair engraving of the cross,-taken from a drawing 
mentioned by Mr. Pennant in his last edition of "London," pagr 93,-now in the British Museum, and published in Is a by Robert Wilkinson, a London bookseller. Though

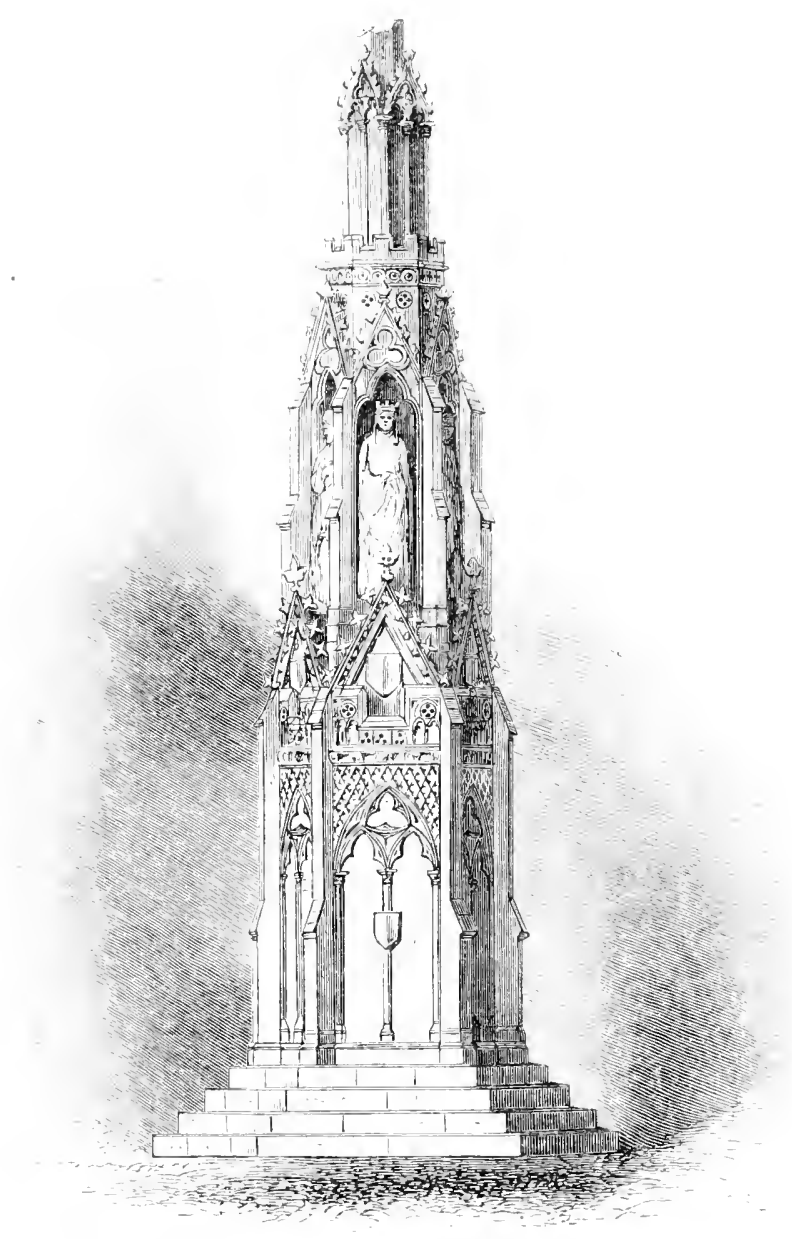

Charing Cross, from the Croate Collection, Liritish Mlescum.

this engrating is far from accurate, there is so much resemblance to the other crosses that, in all probability, it gives 
a tolerably fair iclea, however faint, of the original structure. The cross gave the name to the locality, having been erected for the "beloved queen" (chire rim). The wondcut here given carries it out in its perfect entirety, only altering, and that indeed rery slightly, some few obvious inaccuracies in the details of a kind of architecture then not reeluced to precise styles, but which is now thoroughly understood by all true architects. 
E have already remarked that covered marketcrosses were simply sheltering places for country-people who came with their goods to the nearest market-town; and small as they may seem to our present notions, they were amply sufficient for the wants of their day. Religious houses were mostly near, and as the nave of the church was open invitingly to all comers, it afforded shelter to those who had disposed in good time of their produce; the same thing may be seen now in Catholic countries. The custom has indeed even followed the "Habitans" of Canada across the ocean; these are one and all Roman Catholics, and very simple and devout. They are descended from the old French families who first peopled Canada, and adhere fondly to their language and ancient traditions. There are many roadside crosses along the lanes leading to Montreal. It is really a pleasant sight to see the country-people hurrying off, after selling their market-produce, either to the old church of Bonsecours, about one hundred and eighty years old,-a great piece of antiquity for those regions, - or the more pretentious and really vast church of Notre-Dame, in the French square of that city.

At one time similar scenes might be witnessed in all the 
old English towns. Malmesbury must have been a very picturesque place in the time of Leland, who visited it just before the dissolution of the monasteries. He deseribes it with great conciseness and accuracy, and thus writes of

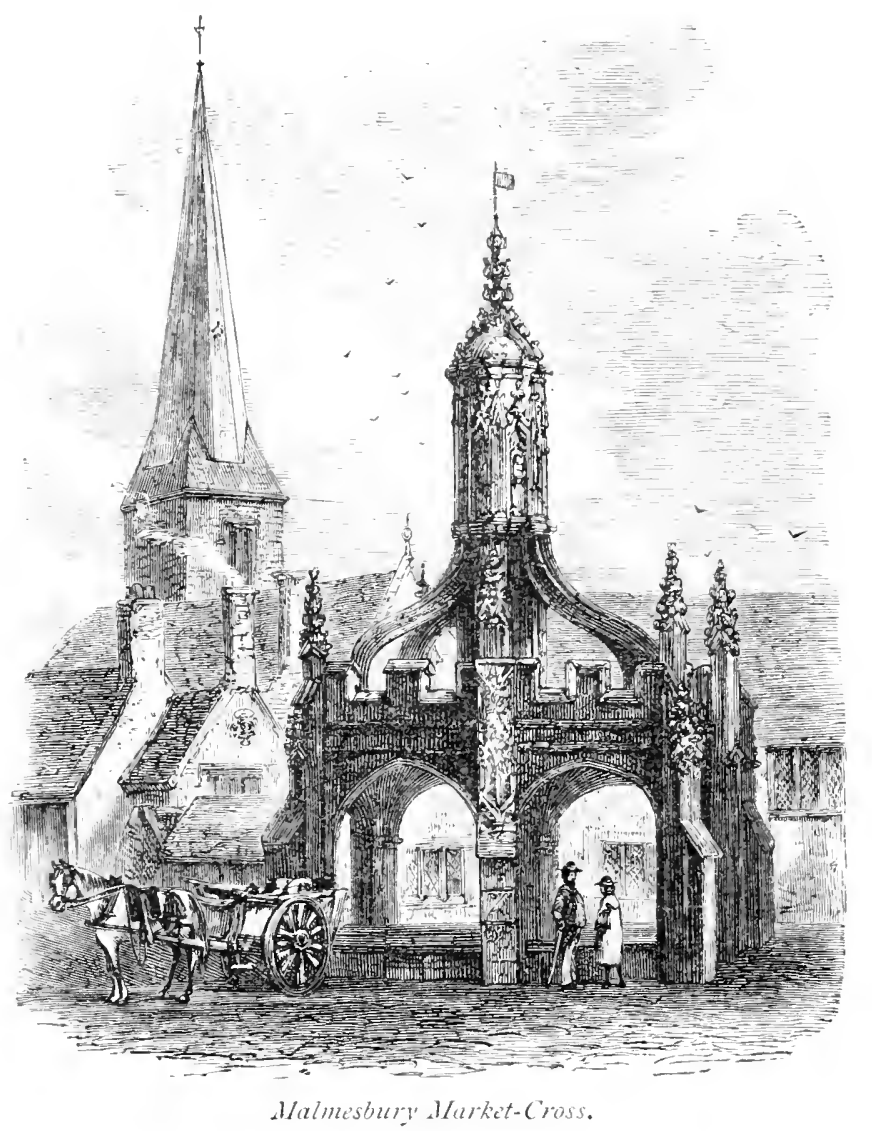

the fine old cross that is here illustrated :- "There is a right faire and costly piece of worke in the market-place, made all of stone, and curiously vaulted, for poor market folks to stand dry when rain cometh. There be eight 
great pillars and eight open arches, and the work is eight square; one great pillar in the midlle beareth up the vault. The men of this towne made this piece of work in homimum momoria. Malmesbury hath a good quick market, kept every Saturday."

On the dissolution of the momasteries, when the abbey officen were sufficiently demolished to satisfy the spoilers, “one Stumpe, a rich clothier," prevailed upon the king to let him purchase the grand old chureh, which he converted, along with the remaining offices, into a cloth-factory: and though we might be disposed to find fault with him for the base uses to which he put it, there can be no doubt he saved the church for the town of Malmesbury.

An interior view of the cross, on an enlarged scale, is also given, showing the style of the vaulting. It was not a covered market, which is a more recent invention, growing out of these beautiful corered market-crosses, as in the cases of Ross and Shrewsbury, which are ilhustrated in this chapter; perhaps the edifice at Shrewsbury hardly belongs to market-crosses, though it was the immediate result of them. The available space for standing under cover in Malmesbury Cross is some three hundred feet, or a little less; there are two openings which reach to the ground out of the eight arches.

Nalmesbury had been a market-town long before the present cross was erected. The abbot, William de Colhern, who died in 1296, built a market-cross there, though no vestige of it now remains; he also developed the resources of the abbey with great energy, rlug fish-ponds and planted vineyards, taking care to catablish a sort of founder's day for himself and his father and mother. For this day, as it 
annually occurred, he set a sum aside to purchase a butt of wine for the use of those whe would pray for the rest of his soul. Ilis name was long and favourably remembered

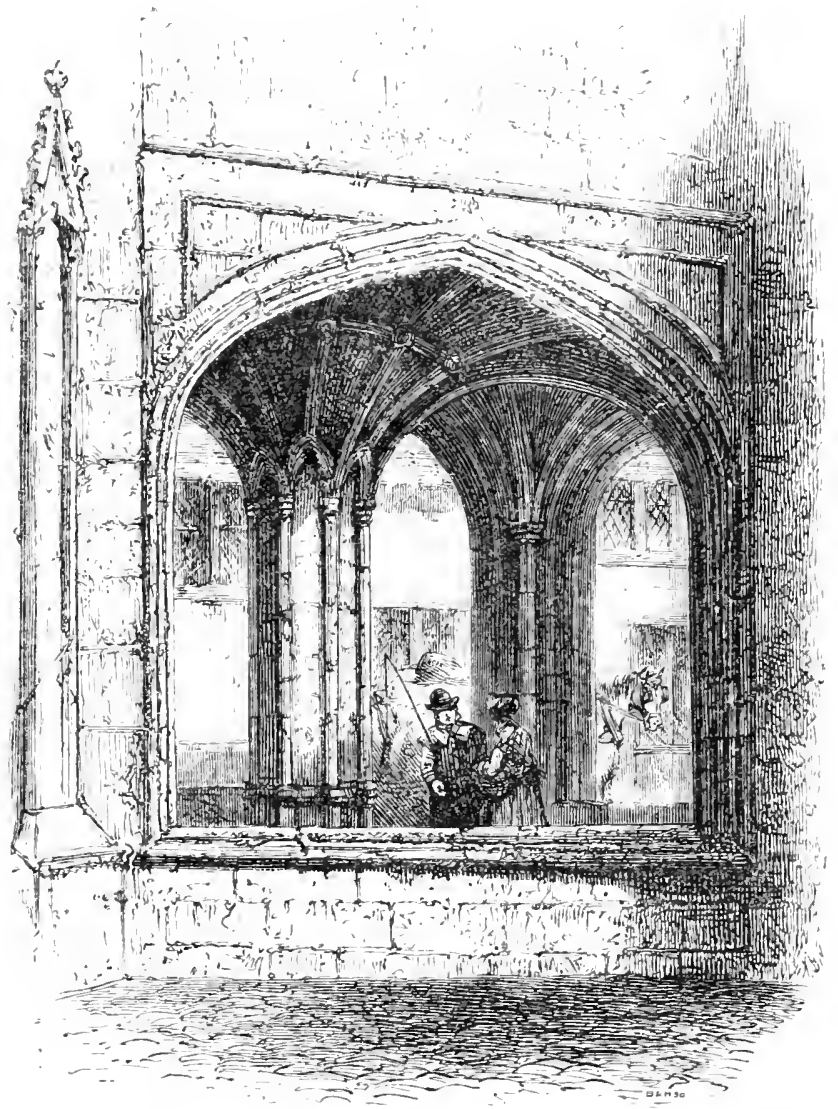

Interior lion of ITalmesbury ITarket-Cross.

by many derotees; a gonlly congregation might always be calculated upon as a certainty on the anniverary. The butt of wine he added, with much simplicity and candour, would enable the people to pray more ferventy. 
Fortunately, Malmesbury Cross is in an excellent state of preservation, and Leland's clescription is as accurate as any we could write at the present time, though when he saw it in Henry VIII.'s reign the cross was one hundred years old. It is to be regretted that there was no Cattermole or Prout in those days to paint the wonderfully picturesque scenes that every portion of Malmesbury Abbey must have presented in those curious times, when the workmen were told off for making the various kinds of cloth prescribed by sumptuary laws for each class of society, all these fabrics being wrought in grand old vaulted chambers.

The proportions of Malmesbury Cross are different from any of the other covered market-crosses in the south. It is remarkable for its heary lantern, and the curious way in which this lantern is made even to give solidity by throwing greater weight upon the pillars, which serve in their turn as abutments for the groining of the interior. Many of the old buildings near the cross belonged originally to the dismantled abbey, but, in their present character, they are changed out of all knowledge.

Chichester market-cross is the most elaborate and imposing in England. It would seem, by its mouldings and gencral appearance, to belong to a somewhat more recent date than Malmesbury, though if Leland's in homimum memorii is to be taken in its literal, and not its figurative sense, that cannot well be. The plan of Chichester Cross is so nearly identical with that of Malmesbury that it has not been considered necessary to give the latter; the only material rifference being that in Chichester all the eight sides aro open to the ground, while in Malmesbury a low 
kind of plinth walling, on which the rustics may be seen sitting, encloses six of its sides. Though Chichester is more imposing, and covers more ground, Malmesburr is

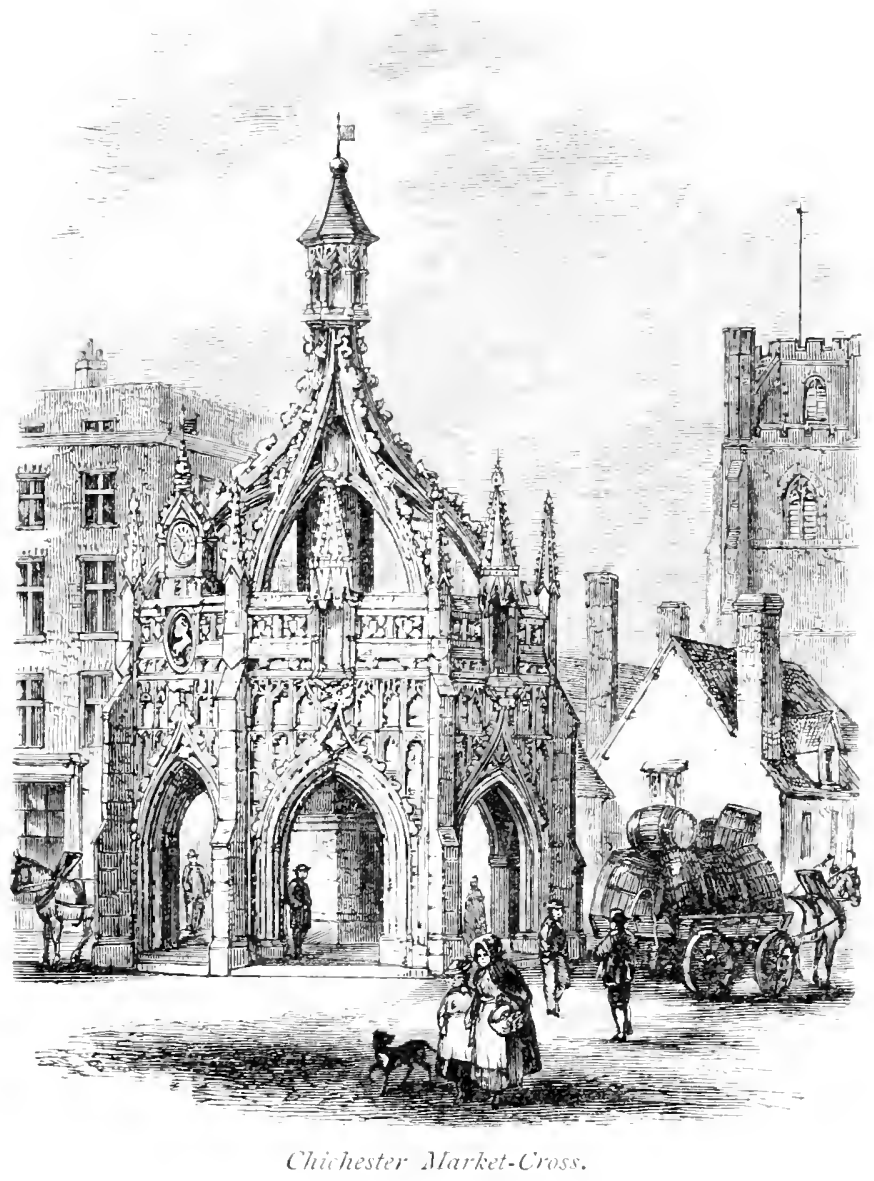

much more elegant in its proportions, with the additional advantage of being more picturesquely surrounded. Chichester affords about four hundred square feet of standing room; this space was not generally used for farm-produce, 
which mostly came to market in covered wageons having waterprouf tops, as we still see covered carts in most rural parts of England.

Chichester Cross was built by Edward Story, who was advanced from the see of Carlisle to this more genial part of the country by King Erward IV., in the year 1475 . It was repaired in the reign of Charles I1, by Charles, Duke

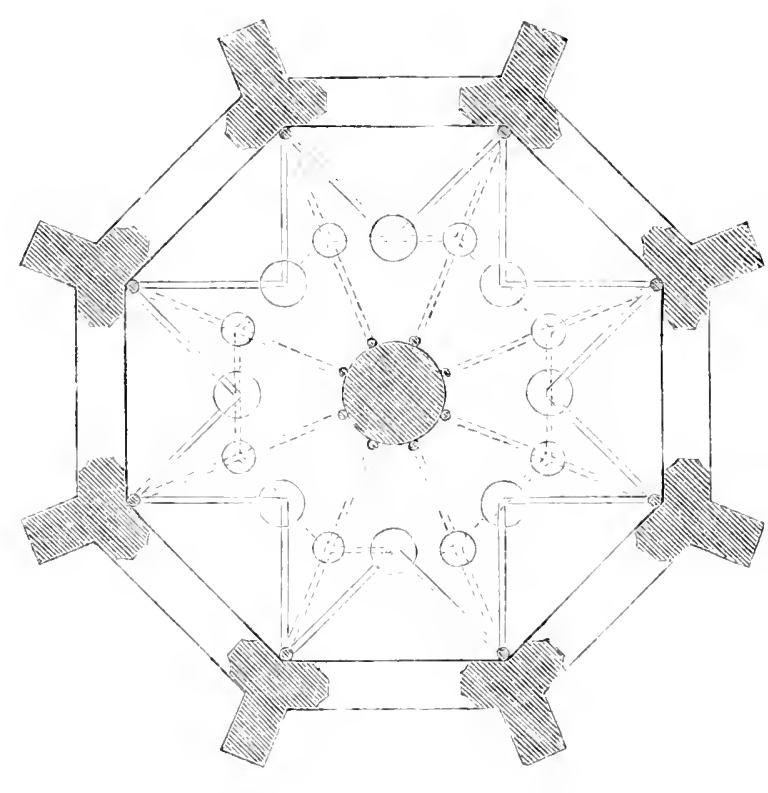

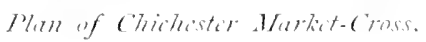

of Richmond, Lennox, and Iubigny; though perhaps there may have been a litte laxity in the disposal of the fund l. ft by the bishop, for he crtainly bequeathed an estate of E. 25 per annum to keep the cross in repair; a very ample sum indeed, to judge of moner at its then value, of which, as before stated, there is not only much uncertainty at the present time, but even much contradiction. The clock is 
recent, and only dates back to 1724. "There is," says Britton, speaking of this cross, "at degree of grandeur in design and elegance of execution superior to anything of the kind in England. The canopied arches, tracery on the surface, sculptured cornice and frieze, with the purfled pinnacles and flying buttresses, show both taste in the architect and science in the mason. This cross, of course, stands in the middle of the city, as was the proper custom in all old market-crosses." It may seem hypercritical to suggest a fault in such a beautiful structure, but even with every desire to acknowledge the general excellence of the design, we cannot but think that the story above the octagonal space is somewhat heavy, and seems rather to have the effect of crushing down the arches on which this beautiful cross rests. Unhappily, the surroundings of Chichester market-cross lend it but little picturesqueness, as the whole city has been modernised to a very consiclerable extent. Some pleasant houses are still left round the cathedral, where church dignitaries reside, but the city in itself is very much changed.

The next illustration, carefully reduced from a fine old engraving, is of a market-cross at Ipswich. Unfortunately, the cross was demolished cluring the present century; otherwise it would have formed a valuable addition to the antiquities of England. It stood opposite to the old Town Hall, an exceedingly picturesque building, which was also removed a few years ago.

On the top of Ipswich market-cross stood a gigantic figure of a female with scales, probably intended to remind the rustics who sheltered under it that they must be true and just in all their dealings. The cross was octagonal, and 
very richly and quaintly carved. The elliptical arches that supported the roof stood on Doric columns of excellent proportions; the roof, ogee in form, was covered with lead. There is a singular resemblance in the character of the ornamentation to that of the well-known "Sparrowe's IIouse," in the same town, of which Mr. Taylor, in his

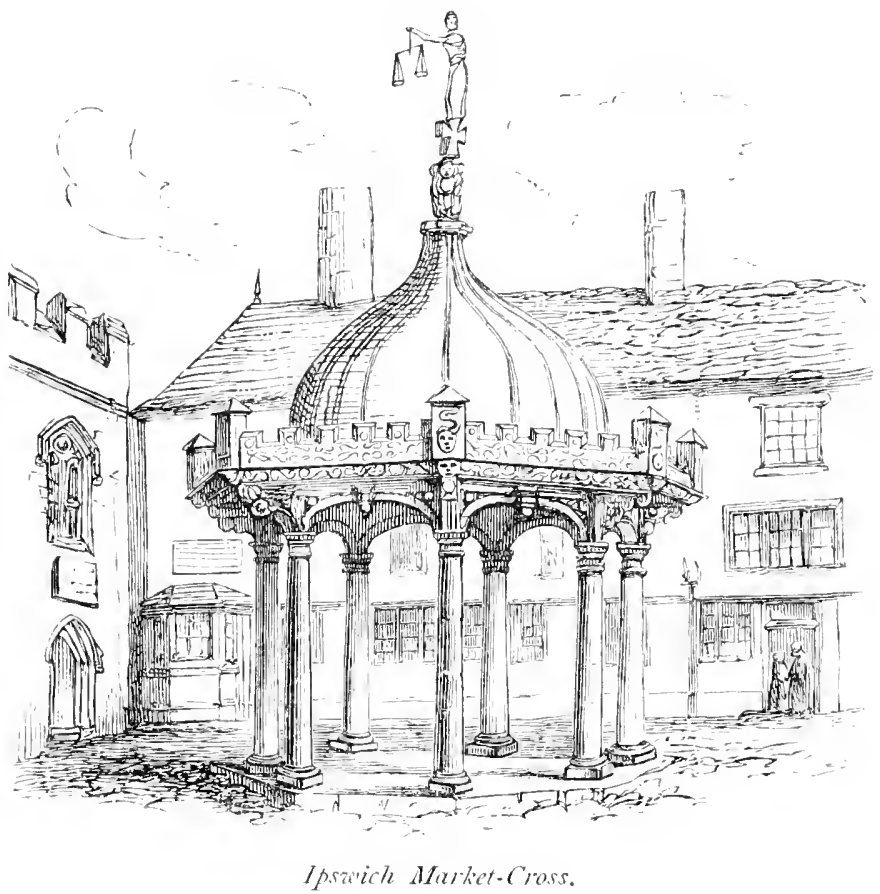

excellent guide to Ipswich, says, "The style of ornamentation, so lavishly bestowed on the exterior, is that known as 'pargetting;' and is one not uncommon in old Suffolk houses of about the beginning of the sixteenth or the end of the fifteenth century." Probably this old house and the cross were nearly contemporaneous: the former, it is 
known, was built by George Copping in the year I 567, and then this interesting city mansion fell into the hands of the Sparrowe family, who occupied it from generation to generation until within a few years since. The last of the Sparrowes who resided in it was the town-clerk of Ipswich.

The cross here given would be an excellent molel for the recently projected cabmen's and carriers' shelteringplaces, which are now springing up in many towns in England; and should such a structure be required in Ipswich, the present greneration will have the melancholy satisfaction of knowing that a beautiful one was destroyed within the recollection of some persons now living. They cannot build a more commodious one, they cannot possibly contrive one so interesting, and they are very unlikely to erect such a picturesque one.

The market-cross of Ross, in Herefordshire, is hardly of the nature of a cross, but is more of a covered markethouse of modern days; and, indeed, it will be the latest we shall have occasion to notice. It is divided into two gables, which cut it in two, and is open on each side; the octagonal form has become quadrangular, and there is a hall over the market. Although the building has a very venerable appearance, it is not in reality older than Charles II.'s time; there is a medallion of that monarch on the front to the street.

This market-place is built of soft red sandstone, very similar to that of which Chester Cathedral is constructed; the stone is in a state of disintegration, and it is owing to this circumstance that it has so venerable an appearance. It stands at the head of a steep, beautiful street, in a lovely country town on the river $W_{y}$, and is directly opposite to 
the house of the "Man of Ross," now converted into two shops. There is a curjous monogram of the Man of Ross on the opposite side to his ald house, which tradition and

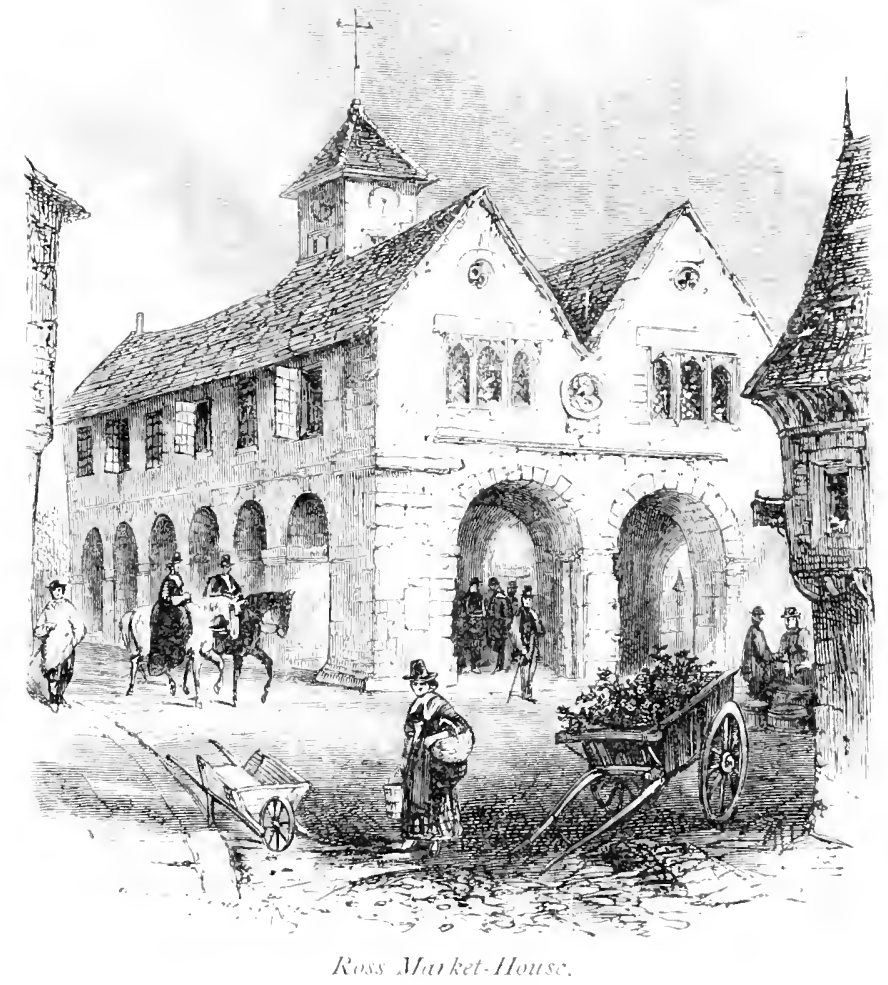

fervid imagination have translated into the somewhat tame legend, "Love Charles in your heart."

Shrewsbury is familiar to nearly overy one who travels in England; it is a delightful old city, full of historical 
associations. The ancient market-hall, hereshown, is not so renerable-looking a builuing as the onr at Ross, though considerably older; but the stone of which it is built is more durable. It is by far the most imposing specimen we have left of this kind of building in England, although, like Ross, it can perhaps harlly be called a market-cross.

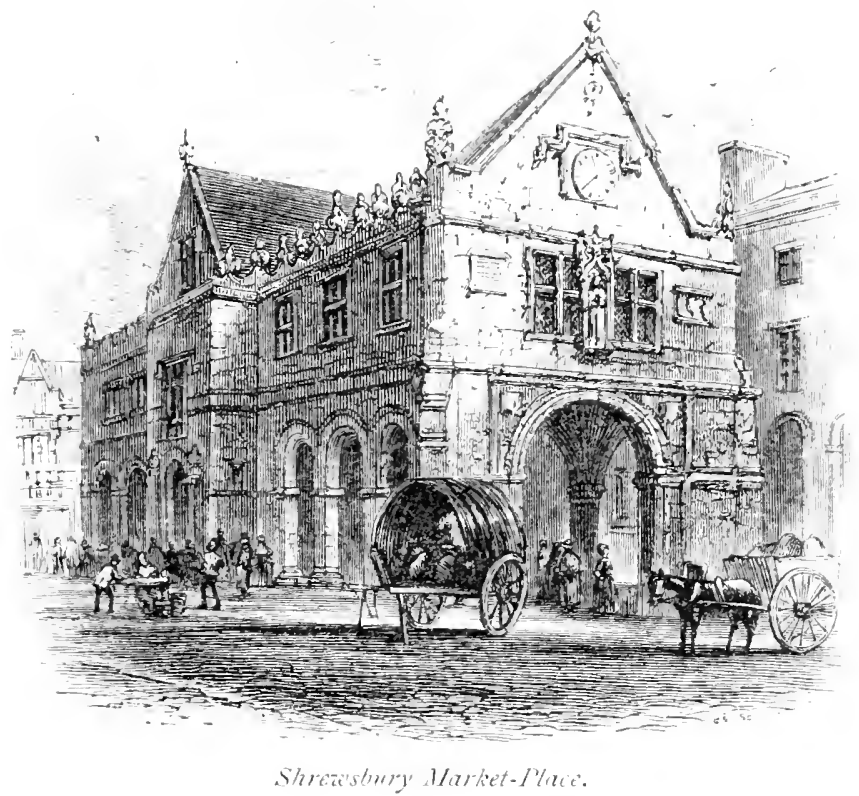

It was built in the year 1596 , and is used at the present time on market-days, being sufficiently large for the requirements of a town like shrewsbury. The standingroom for market-people is fully three hundred square yards. A rery large market has, however, been recently erected in the vicinity in addition to this.

Shrewsbury market-house, though gond in design, is 
rather debased for the period, the moulding and general ornaments being more like those of the reign of Charles I.; there is a curious kind of scroll along the sides, which takes the place of battlements, and is rather heavy in appearance. The houses round the market-square have, in a great number of instances, been modernised, but there are still some fine specimens of antiquity left.

There is a curious and very beautiful open octagonal pulpit, apparently of the fourteenth century, standing in a racant space in Shrewsbury, which has sometimes been taken for a preaching-cross, like Hereford; but it is, in reality, only part of the old abbey that has had the good fortune to survive destruction. The High Cross of Shrewsbury has long been clestroyed, but its place is pointed out in old documents. Unhappily, it is not connected with pleasant associations, for before it the last of the British princes, David, a brother of Llewellyn, was cruelly put to cleath by Edward I.; and at a later period many of the nobility who were taken at the battle of Shrewsbury were there executed, the High Cross being considered the most appropriate place for such a spectacle.

At one time Shrewsbury market-place was the principal exchange for the sales of Welsh flannels, and its extraordinary size may thus be accounted for; but, with alterations in the way of conducting business, this advantage has left it, and it is now entirely a farmers' markethall. It is almost needless to add that the clock in the gable is not, as many visitors suppose, the celebrated Shrewsbury clock to which Falstaff alluckes; that is the clock of St. Mary's Church, on the other side of the town.

The gables of Shrewsbury market-cross are generally 
allowed to be well-proportioned, and the outline of the structure is exceelingly picturesque; exception may be taken to the exceeling coarseness of the curves of the enrichments, but this fault belongs entirely to the age in which it was erected.

In nearly all those places where the market-crosses just alluded to were built, there cannot be a question but that more ancient ones preceled them ; the various accounts of meetings at the cross, and even of legal documents being sometimes described as executed there, would confirm this.

There are covered markets now in almost every city or town of any importance in England. In Chester a new and very capacious market-place has been built in what is commonly called Northgate Square; it joins the Town Hall, and presents a gable only to the road, but it has not superseded a meat-market that still stands in the square, perfectly detached, and is only open once a week. In York there is not even yet a covered market, but the farmers comc as of old in covered carts, and bring their produce; it is true, indeed, that some of the inhabitants have moved for a new market, and have urged the site to be that of the ancient parliament house and some curious buildings at the lower end of Samson Square, by which proceeding a fine block of old domestic architecture would be destroyed. But better counsels have prevailed in the meantime, and let us hope that, through the increasing interest now manifested in the question of preserving old monuments, such desecration will not be allowed; for surely there is room enough in Yorkshire to build coverecl markets, and yet to spare the few hundred yards of ground whereon these old relics stand. 


\section{YI.}

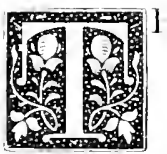

HE Cross of Newark, which furms the subject of the first illustration to this chapter, has often been erroneously called an Eleanor Cross; it is apparent at a glance that it belongs to a much later style of architecture. It was built by the Duchess of Norfolk, who married John, Viscount Beaumont; he was slain at the battle of Towion-Moor, in Torkshire.

That England should have been the scene of the most fearful battle-fields seems now almost incredible; but we are so familiar with the vivid pictures Shakespere has given of the wars of the Roses, that they appear, as we read him, more real than even the comparatively recent struggles of the Commonwealth. The great battle of Towton, which took place March 29, 1.6 I, is thus described by lIall:-_"This battle was sore fought, for hope of life was set on side on every part, and taking of prisoners was proclaimed as a great offence; by reason whereof every man determined either to conquer or to die in the field. This deadly battle and bloody conflict continued ten hours in doubtful rictory, the one part sometime flowing and sometime ebbing; but, in conclusion, King Edward so courageously comforted his men, refreshing the 
weary and helping the wounded, that the other part was discomfited and overcome, and, like men amazed, fled toward Tadcaster bridge to save themselves. . . This

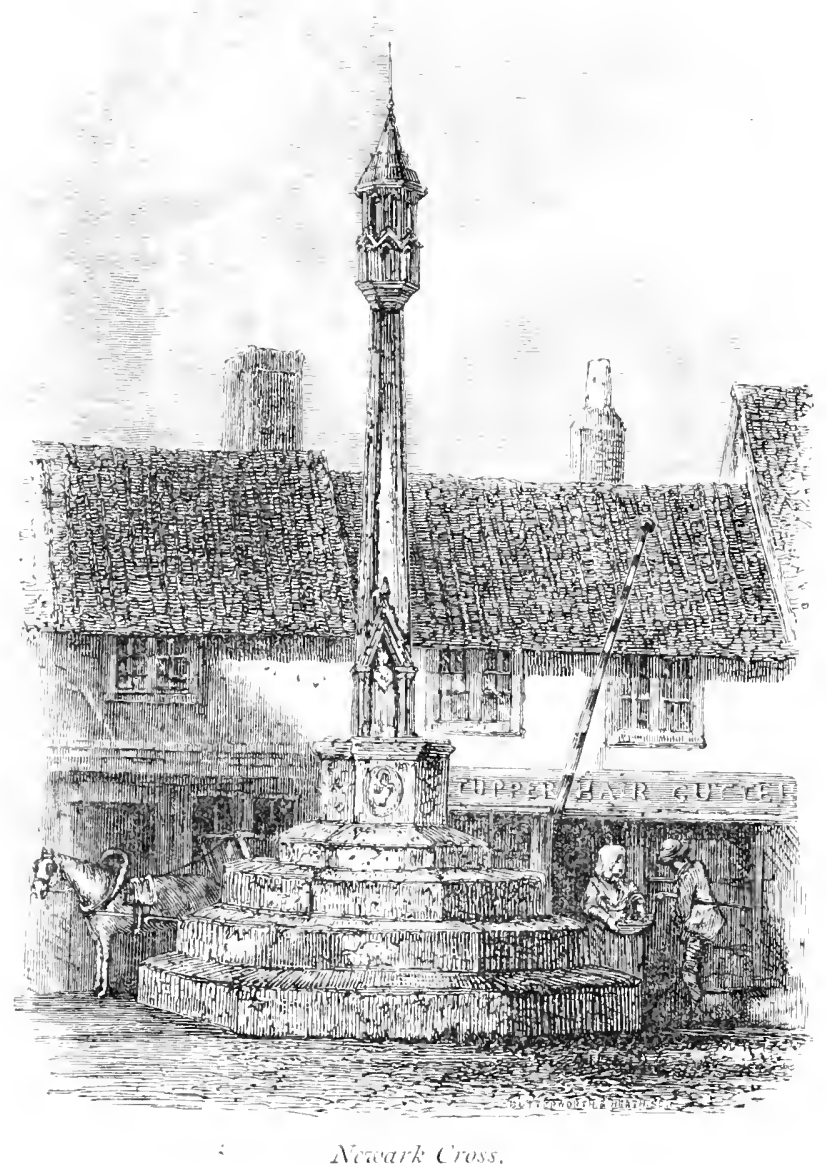

conflict was in manner unnatural, for in it the son fought against the father, the brother ayatinst the brother, the nephew against the uncle, and the tenant against his 
lord." Above thirty-six thousand men are computed to have fallen in the battle and pursuit.

Shakespere, in the Third Part of King lliny l\%, (lescribes with his usual felicity the distressing features of this great civil conflict. There is a son who had killed his father without knowing him :-

" From London by the King was I press'd forth ;

My father, being the Enrl of Warwick's man,

Came on the part of York, press'd by his master;

And I, who at his lands received my life,

Have by my hands of hife bereaved him."

And then there follows the scene of a son killed in like way by his father, who says-

"What stratagems, how fell, how butcherly, Erroneous, mutinous, and unnatural,

This deadly yuanel daily doth beget!O boy, thy father gave thee life too soon, And hath bereft thee of thy life too late!"

Newark, by the old roads, would be about serenty-three miles from Towton, and here the body of Beaumont was brought for interment, and the cross of which we are writing was erected by his widow to his memory. It is a valuable example of a memorial cross, as the date is so completely fixed; and, singularly enough, at Wakefield there is a most beautiful chapel, built on the bridge over the Calder, to commemorate those who fell on the other side of the combatants. The canopy of this cross has been restored in recent times; in all probability it was tabernacle-work originally. In an engraving, apparently about ninety years old, the present canopy is not given.

The Cross of Ileadington, in Oxfortshire, is a fine old specimen of fourteenth-century work. To some extent it 
bears a resemblance to Newark; but it has the advantage of a fine base, composed of quarter-foils, which enclose a kind of open book in the middle.

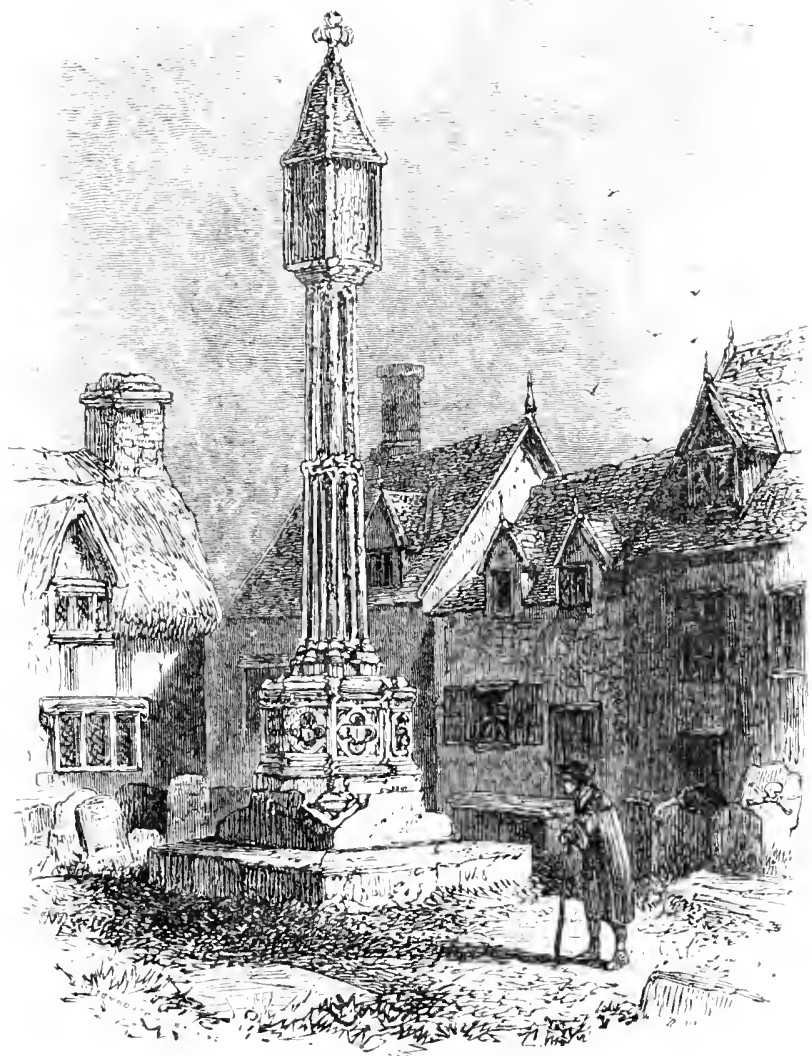

Headington Cross, Oxford.

King Edward the Confessor was born at Islip, near here, and for some time he lived at Headington. The palace of his father Ethelred was in the neighbourhood: its site is believed to be in the grounds of a house called 
the Roukery, in the vicinity. The date of Ileadington Cross is uncertain; but it is inclisputable that in the fifteenth century the lings of England had a chapel in the

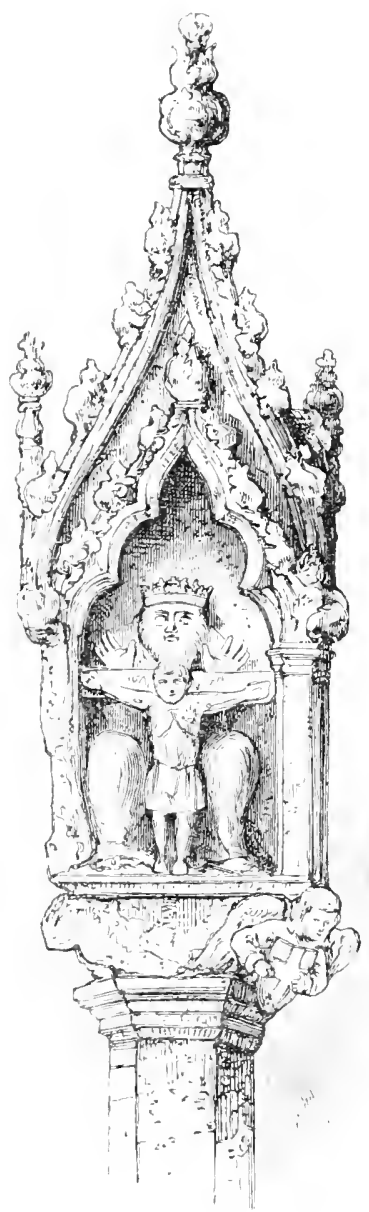

Mirat of Hemle' Cress. royal manor of Ileadington, and equally certain that the cross was standing then. The head of the cross is modern, and simply a kind of rude tabernacle-rork. It belongs to the same class of heads as that of Henley, in Warwickshire, which was probably a contemporaneous structure, and another at Delamere, which has only recently been exhumed.

The head of Henley Cross is here given; it is very curious. There is a most singular carving of the crucifixion overshadowed entirely, as it would seem, by the Supreme Being in the act of benediction. Perhaps there is nothing like this in England, nor can we recollect any similar ancient derice in any other country. This head is borne lip by four angels at the angles, which seem never to have been surmounted by pinnacles.

There is a very remarkible cross at leighton, near liwlford, commonly called Leighton-Luzzard. The affix 
of Buzzarel has been consicherel an ablorevation of " lieaudesart." This, we think, is a mistake. In old documents it is spelt Josard and lozard. There was an old family

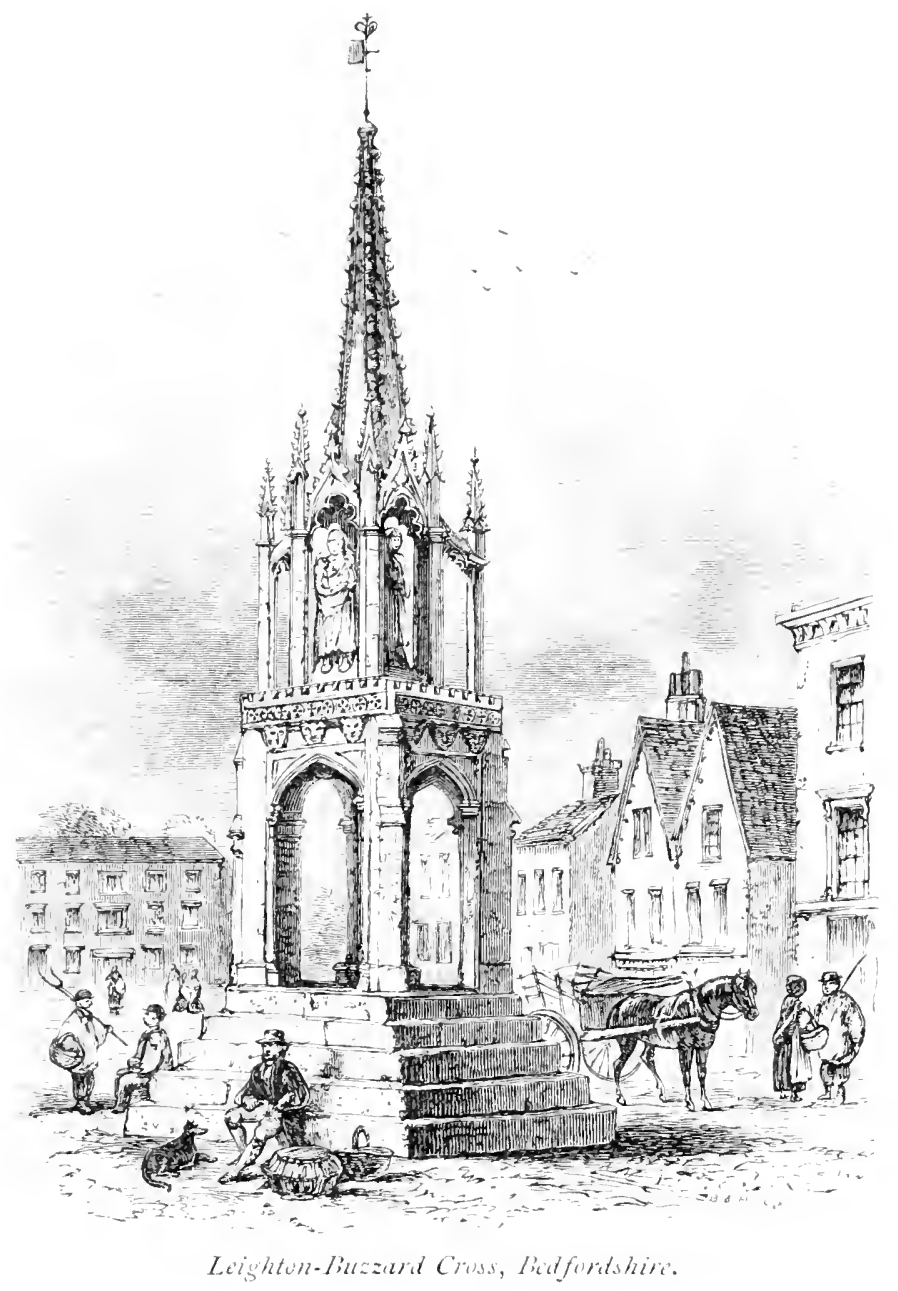

of that name in the reign of Echward L, and they appear again in Edward Ill.'s time, as knights of the shire. 
This cross would seem to date back to the reign of IIenry VI., so far as its mouldings and general character may be taken as an indication. It is pentagonal in plan, is twenty-seven feet high, on a base of five steps, with pinnacles, fifteen heads, and niched figures; there is a strong central column. It was restored in 1650 . Notwithstanding all we can say in praise of the unerring skill of mediæval designers, any form of uneven sides is not satisfactory; as we have before remarked, it must of necessity throw one sicle out of the centre in nearly any position from which it may be seen; this defect is very much more noticeable in the otherwise exquisite cross of Geddington, one of the Eleanor crosses illustrated in a previous chapter.

Leighton-Buzzard Cross appears to have been originally designed for three stories, though there is no evidence that it ever was carried out according to this plan. The abrupt termination is very striking, giving the structure a heavy and ungraceful appearance. If another stage be added, the improvement will be plainly seen.

The once celebrated Cross of Abingdon, in Berkshire, was built by the brethren of Holyrood Cross, who were a fraternity belonging to the Abbey of Abinglon. Among the governing body were Sir John Golafre and Thomas Chaucer, the son of the poet; the latter, it is generally thought, was coneerned in designing Abingdon Cross. It has been deseribed by Leland as " a right goodly cross of stone, with faire degrees and imagerie," situated in the market-place. This cross was repaired in the year 1605 by the gentry of the neighbourhood; and an incident like this show's that, notwithstanding the sudden reception of 
a foreign style, a real admiration of genuine English architecture was not by any means extinct. One gentleman subscribed the sum of L.30, a large amount in those

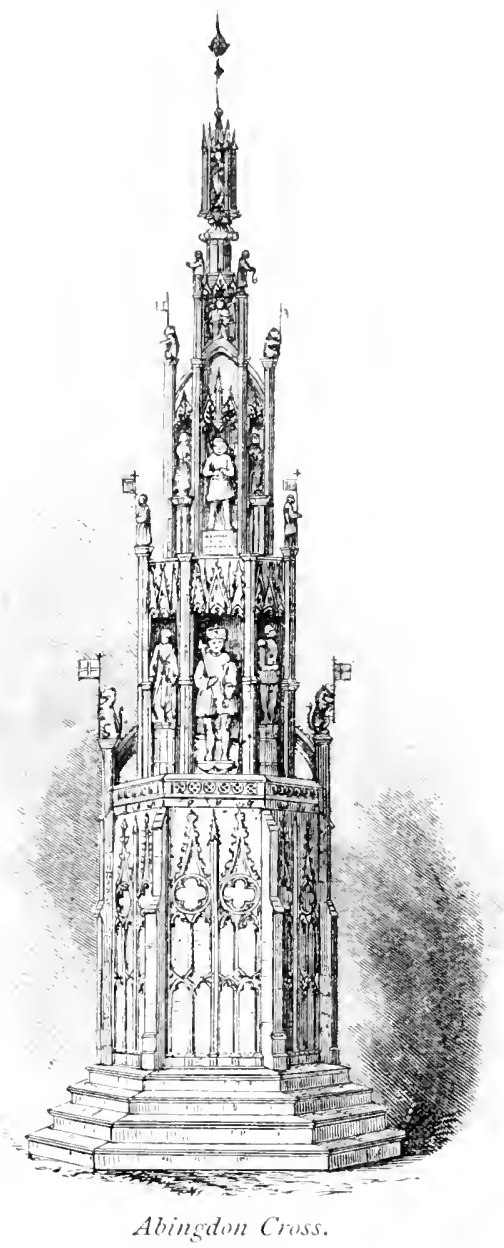

days for any such purpose. At the treaty with the Scots in $16+1$, a gathering of two thousand people sang the 106th Psalm at the cross. It was a curious circumstance 
that they should select that place for this particular ceremony, as all crosses were proclaimed idolatrous by their preachers. Already many grand old monuments had been senselessly swept away; Abingdon Abbey was destroyed a century before, as were many of its fellows; glorious relics of architecture were heaps of stones, which from that day even to this have served to build barns and granaries. Time has now transformed many a demolished building into a pleasing ruin; then, however, the breaches were recent, and the remains uncovered with moss. But these things did not move them. The intolerant fury against what were called superstitious edifices, which has destroyed so many beautiful monuments of art both in England and Scotland, decreed the destruction of Abinglon Cross, and it was "sawn" down by Waller's army in 164t. Even Richard Symonds, an officer in the Cromwellian army, paid a tribute to its beauty.

Coventry Cross was built, it is believed, after the same design as Abingdon; and though the former is also destroyed, we are in possession of abundant documents and drawings to show what it was like. It is later in style than Waltham, and much more Horid. Perhaps, indeed, it cannot fairly, considering its date, be compared with that incomparable work of art; but it must have been very grand when complete. Britton, in the "Antiquities of linglish Cities," gives a most interesting account of it. It was so richly gilled, that we are assured when country people came to Coventry, they could " hardly bear to look upon it when the sun was shining." The history of this cross is somewhat curious. It was built at the cost of sir William Hollis, who made a bequest for that purpose, 
himself laying the first stone. It was erected on the site of an ancient cross, of which we have been unable to find any record or description. The town leet of that time were duly sensible of its worth, for they passed laws to protect it from injury. Among these was a fine of three shillings and fourpence for sweeping dust in the enclosure -the cross-cheepinge as it is called-without previously sprinkling the dust with water to prevent its rising upen the gilded work of the cross.

The regilding of this magnificent structure, in the year I668, used up, we are informed, 15,703 books of gold. It is quite an unsettled question how far this mode of decoration in the open air is consistent with J Iigh Art. It is true the Greeks used it to a very great extent, and the Acropolis was at one time a rast mass of coloured marble buildings. Great allowance must be made for the climate; it is well known that steamers plying between the Mediterranean ports and England soon find a difference in the polish of the brass fittings, for there they remain bright for many days, while in Liverpool or London they become dim, if polished ever so carefully, after being for a few hours in either harbour.

The cost of repairing and regilding the cross in 1668 was the large sum of $\$, 2762 s .1 d$, and the articles are yet in existence which confirm the agreement. The Mayor of Coventry, in his official capacity, seems to have made the bargain for the restoration with one John Sweyne, who resided at Brereton, in Cheshire, and his arocation seems to have been "stone-cutting." It seems almost incredible that the beauty of this cross should not have preserved it from deliberate destruction even so lately as the close 
of the last century. It was considered by the sapient inhabitants to be behind the age, and rather in the way!

Some features of Coventry Cross are very curious; fortunately it is preserved in an excellent copper-plate engraving, now not procurable, published by T. Deago, of

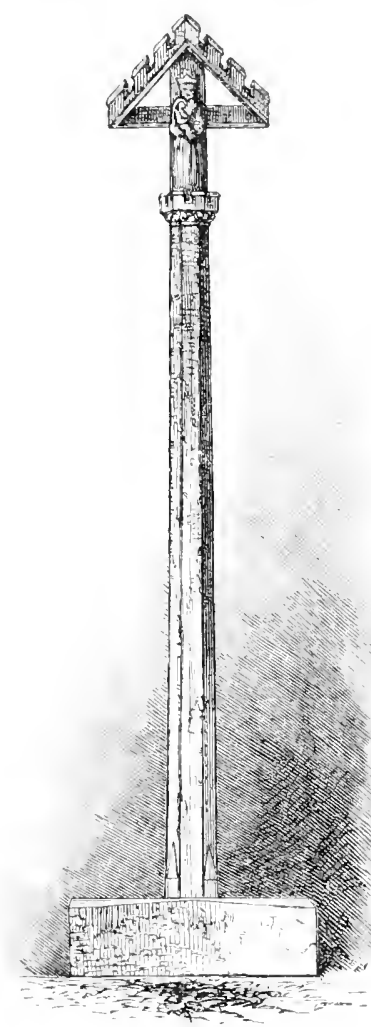

Somisby cross. High Street, St. Criles's. There were a vast number of figures on it; at the summit was a statue of Justice with scales, and on the opposite side one of Justice with a sword. Siightly above these was a figure of Mercy with an extended arm. The total height of the cross was nearly sixty feet.

The last cross we shall allude to in this chapter is Somershy, near Horncastle, in Lincolnshire, which is widely different in appearance from any we have as yet consiclered, and, incleed, is quite unique in England. It is fifteen feet in height, is surmounted by a triangle, embattled, and the top of the shaft has an embattled head. In other respects it is a tall, graceful column, octagonal, and springing from brooches which rest on a square pedestal. On one side is a figure of the Virgin and Child, and on the other is the Crucifixion. 
AMCIENT STONE CROSSES OF EVGLATD. BI

This cross is pleasantly situated in the churchyard of Somersby, on the south side of the church. W'hether it is a memorial or a weeping-cross there is nothing to determine; nor, indeed, can we discover the date of its erection: it may have been about $\mathrm{I}+50$, judging from its general character. The church presents few points of interest architecturally: the living has long been in the gift of the Burton family, who are lords of the manor. 


\section{VII.}

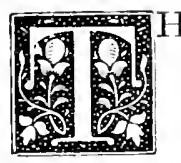

HERE are many crosses yet standing in England that date back far beyond the Conquest, and far beyond any ecclesiastical buildings, even among those that are in ruins. These ancient

- relics are most curious and instructive, reminding us how little we know of Britain from the time the Romans left it to the time when, under the iron sway of William of Normandy, it was consolidated into the kingdom it has remained to the present day. There is a long hiatus from the Roman period to the early dawn of recorded history, over which all the chronicles we possess cast but an uncertain light.

In the year $39^{8}$ Stilicho sent effectual aid to the Roman colonists in Britain, who felt the loss of the legions that were recalled for the defence of the capital ; and for awhile they were protected against the savages of the Grampians, and the adventurers from the Elbe and the Baltic. It seems strange, when we contemplate such rast Roman remains-splendid cities, villas, and roads which were not equalled until Telford's time-that the colonists could do so little to protect themselves against rude tribes. Honorius tried to arouse them, but he tried in vain; and after sending them aid A.D. 422, he left them to their fate. 
Among the emigrants that continually came from Rom. were not a few Christian converts. St. Ninian arrived as early as about the year $35^{\circ}$, and founded a monastery in Galloway. Many others followed, and St. Columba, who was born in Ireland in 521, landed about two centuries after St. Ninian in the desolate dominion of the Picts, and with twelve friends founded the monastic retreat of Iona. Now, as missionaries were sent out from these homes of Christianity, it is easy to comprehend how forms of ancient crosses may have been transported to various parts of England; yet so far we have not been successful in finding the dates of the oldest of them.

There is a singular resemblance between the architecture of these crosses and other remains of antiquity of which history leaves us in the lark. The Runic sculptures have a strikingly Eastern appearance. It may, of course, be quite accidental, but it is a singular circumstance that the ancient rites described by Stephens in his "Ruins of Central America," and well delineated by him-those mysterious and rast cities round which hard wood foresttrees have grown, and quietly thrust up stones weighing many tons-seem to have travelled round the globe by the East. This ancient architecture appears in China, and on some Pacific Islands long deserted; it is strongly developed in Hindostan among the ancient ruins, and there are many traces of it in the older cities of Italy, which had arrived at a high state of civilisation long before Rome was built. The coincidence of design is curious, but the cross at Carew, or the Runic stone at West Kirby, might easily pass for stones from the very farthest East.

The "old crosses" at Sandbach, in Cheshire, have long 
been considered to be the most interesting and ancient Christian relics in England. Sandbach is situated in a

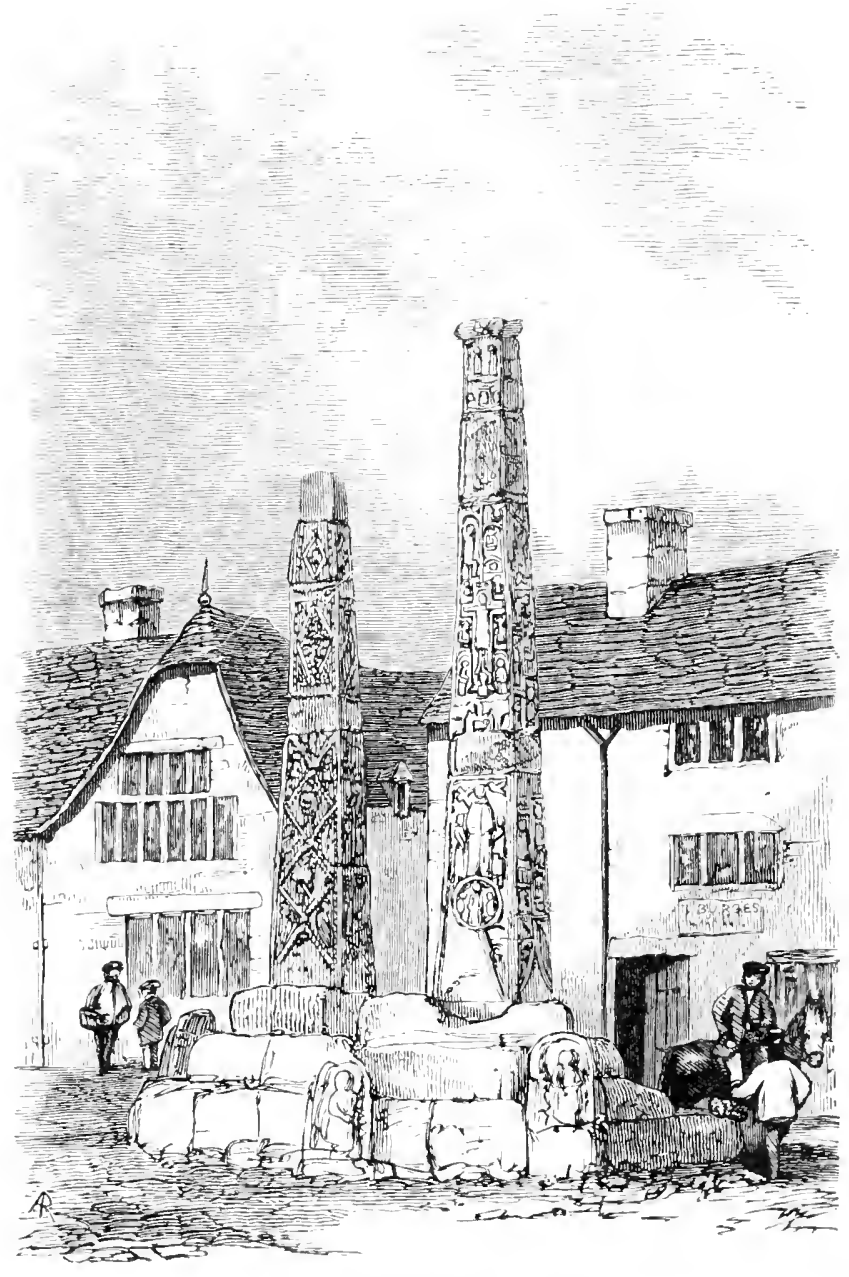

Crosses at Sandbach, Cheshire.

rather uninteresting part of the county, though there are some excellent specimens of antique architecture in the 
neighbourhood; among which are Crewe Jlall, and the old hall at Sandbach, now used as an hotel and as an office for I.ord Crewe's agents.

An excellent account of these crosses has been written by Lysons and Ormerod. It is supposed that they were raised on the spot where a priest from Northumberland first preached Christianity, and that they were erected in the eighth century. Startling as this date may seem, there appears little reason to loubt its accuracy. The stone they are cut from is the very hardest of the lower silurian formation, and seems almost to defy abrasion.

On the lower part of the east side of the higher cross is a circle (shown in the engraving), containing what in all probability has been correctly called the Salutation of Elisabeth; the figure in the centre is supposed to be from Luke, "The power of the Highest shall overshadow thee." Above this circle is the "Annunciation," "Behold from henceforth all generations shall call me blessed." Above this is a sculpture of the Crucifixion; at the foot of the cross are the figures of Mary, wife of Cleophas, and Mary Magdalene; while in singular grotesque series are the emblems of the Four Evangelists : these are just indicated round the intersection of the cross-that is to say, an angel is cut for St. Natthew, a lion for St. Nark, a bull for St. Luke, and an eagle for St. John.

There is much precision about the sculptures, and an infinite amount of action, as in the bringing of Christ into the judgment-hall, Pilate seated on the judgment-seat, and the contrition of Judas-it will be remembered that Judas repented of his treachery, and cast down the thirty pieces of silver in the Temple, and he is here represented with his 
head depressed, as showing his remorse; above this, over the plain blank stone, are certain figures that are said to represent the "implements of the passion," such as hammer, pincers, \&c. ; but this sculpture is much mutilated.

A local description of these singular meckallions, which is at least careful, says:- "On the west side of the cross is a plain cross; in the lower quarters are two chead, fiencllike animals, in the act of biting the transverse part of it; their tails are fretted, gnawed, and terminated with a snake's head." This is obviously the seed of the woman bruising the head of the serpent. Higher up is a rude representation of the angel Gabriel appearing to Zacharias in the Temple, who is seated on a chair, struck dumb. Quoting the local description above alluded to, "Above is a man walking with a club in his hand, and followed by Simon the Cyrenian, carrying over his shoulder the cross." Of course this may be the correct interpretation, but in such rucle sculpture there is much that is merely conjectural. As there are two unmistakable stars in each panel, it would perhaps be more consistent to consider them as the Magi: "We have seen his star in the East, and are come to worship him." This would be more consecutive as to time, for the panel immediately above is saicl, and perhaps correctly, to be the bringing of Christ bound before the judgment-seat.

Another sicle is filled with beautiful filigree-work, not at all inconsistent with the late Colonel Forde's theory of the still greater antiquity of the crosses than that already suggested. He attributes the clate of their erection to the seventh century of the Christian era. It was owing to him that the fragments were collected and restored as far 
as they have been; he was Lord of the Manor of Sandbach, and a very accomplished antiquary. It is a very singular circumstance that on a cross at Kells, in Ireland, the sculptures of which resemble those on the large cross at Sandbach, there are undoubted Roman knights and horses, and a very perfect centiur, with a bow in his hand.

A.

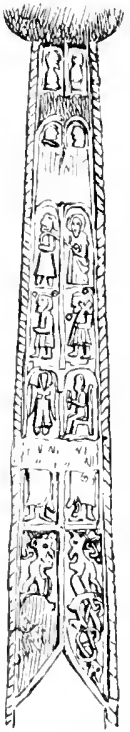

(A.) Hest side of large Cross.
]3.

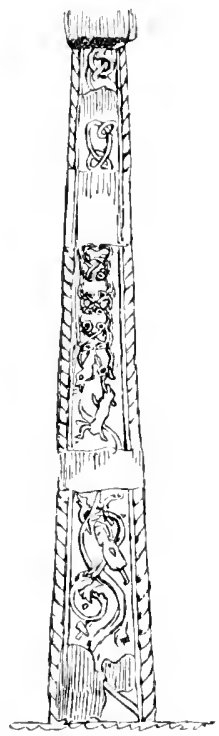

(b.) Sunth side.

The crosses in Ireland, it is needless to remark, are very much more ancient than those in England.

On the north side of the large cross are a succession of figures one over the other, and this is said to represent the "descent of the Holy Ghost, in the shape of cloven tongues, to the Apostles; they are placed in narrow cells, in a clouble row from the bottom: it is remarkable to 
observe that the division on which each stands is cut off at one hand, so as not to touch the sides, leaving an uninterrupted communication between the whole, which is not observable in other parts." This very peculiarity, however, would almost seem to indicate a "Jesse tree," an ancient and farourite emblem, and the sculptures would then represent the Holy Ghost descencling in the form of a dove, and the "Apostles" would be the row of ancestors, "Which was the son of Heli, which was the son of Matthat, which was the son of Levi," \&c., \&c.

"The north sicle of the small cross is divided into a double row of cells, in each of which is a man, all in the act of walking, some with short daggers in their hands, others without, which in all human probability represents Peda setting out from Mercia with all his nobility and attendants from Northumberland to solicit the hand of Alchfleda, King Oswy's daughter; and on the west side is a triple row of figures in small cells, and a tableau which is supposed to represent Peda receiving baptism. On the south side are like figures to those on the north, all travelling on; but instead of daggers, they carry staves in their hands. The version which the local description gives of these being Peda and his attendants is most probably correct, for Peda was the son of Penda, the King of Mercia, who was always at war with neighbouring princes. He was deputed governor of the Middle Angles, and arrived on a visit to Oswy, the King of Northumbria, who had embraced Christianity, and sought the hand of his daughter Alchfleda, for whom the pagan young prince had conceiver a great passion. Ile was allowed to marry her on condition of his embracing the Christian faith. 
This he consents to, and returns with his bricle and some priests to his own court, promising that the priests should have every opportunity of preaching the Christian religion."

The east side of the small cross is exceedingly curious, and it is doubtful if any ingenuity of interpretation could make anything out of it the events or circumstances to which it alludes are, in all probability, not recorcled in history. There are five lozenge-like compartments, though originally there were more, and the interstices are filled with figures of men and animals; in the uppermost lozenge is the figure of a bull, with his head reflected on his back. In the top part of the next lozenge is the figure of a man, with his hands stuck in his sides, and his feet extended from one side of the lozenge to another. In the base are two men endorsed. The next is partly mutilated, but seems to have been filled in with something of the reptile kind; and in the next two are men with clubs in their hands. The whole of the subjects on this side are enclosed in a curious fretted margin, laced and indented, but of exquisite design and workmanship.

It is uncertain when these crosses were mutilated, but great violence has been necessary to pull them down, for the large cross in its fall has torn away a great part of the socket-stone in which it had been firmly fixed, on the opposite side from that on which it fell; the bottom part was split with wedges, and long served to protect the sides of a neighbouring well, while other fragments of this truly interesting relic were used as doorsteps and guards for the corners of walls: some parts were taken to Oulton Park, the seat of Sir Philip de Malpas Egerton, where 
they served to adorn a grotto. The restoration of these relics was entrusted to Mr. Palmer, of Manchester, and he had the valuable assistance of Mr. Ormerod, of Sedbury Park, the author of the " History of Cheshire."

It may be remarked that the whole of the groups in the larger cross are from scriptural subjects, while those in

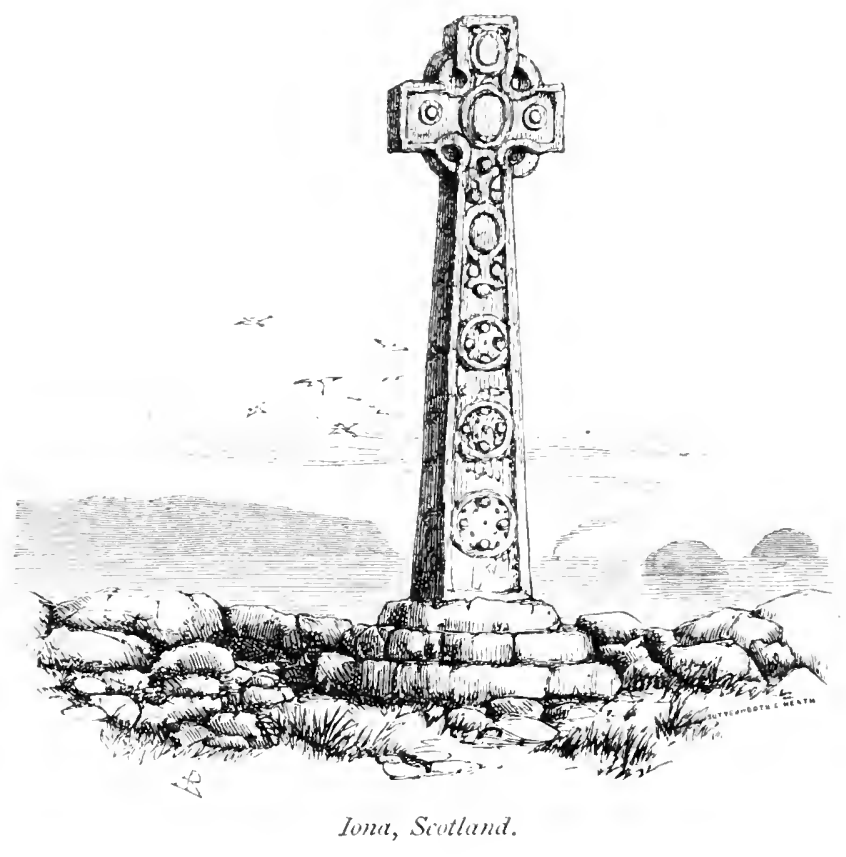

the smaller one relate most probably to secular history, much of which must for ever remain unknown, as in all probability the events portrayed in the panels are not preserved in any listory, and these rude old sculptures are the only record left. They were originally terminated by a form of cross and circle, similar to those in Scotland or in Ireland, but these have long been destroyed: never- 
theless they are most interesting and well-preserved relics of antiquity.

Nuch similarity of character will be observed between

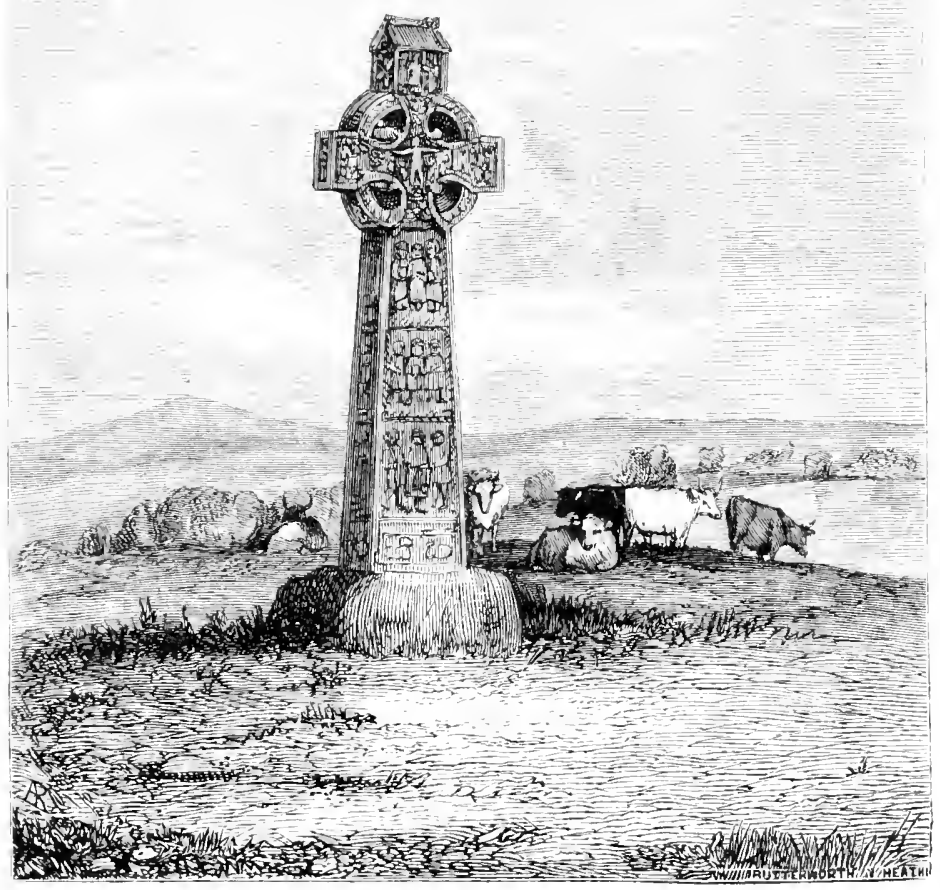

Monasterboice, Louth.

the crosses of Sandbach and those of Iona, in Scotland, and Monasterboice, in the county of Louth, both of which 
are here shown for the sake of comparison. When Boswell and Johnson visited the ruins of Iona, the former was much disappointed with the rude remains,-having pictured to himself sculptures hardly, if at all, inferior to those of Westminster. Abbey,-and expresser his surprise to his companion, who made the woll-known rejoinder: "We are treading now the illustrious island which was once the luminary of the Caledonian regions, whence
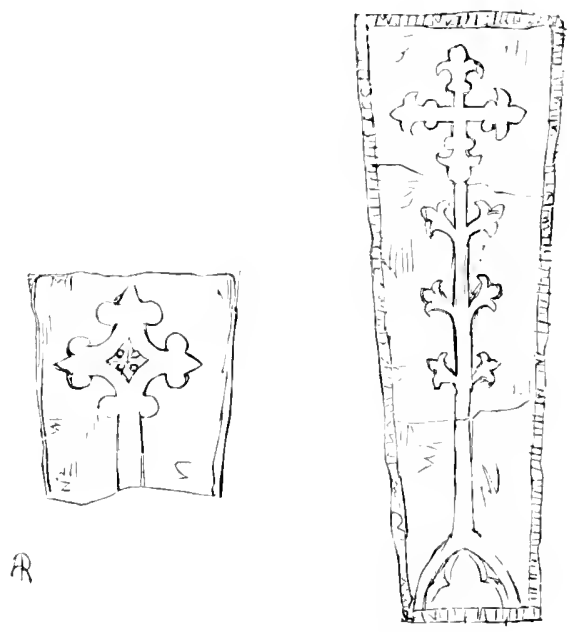

Inciscd slabs. Chester Cinthidrat.

savage clans and roving barbarians first derived the blessings of religion. Whatever withdraws us from the power of our senses, whatever makes the past, the distant, or the future predominate over the present, advances us in the dignity of thinking beings."

The monastery of Iona was at one time a splendid seat of learning, whence priests were sent out into all parts of the world, and where in their pilgrimages they met with 
brethren from the south on their travels to the north; and thus, while a distinctive character is maintained in the crosses they caused to be erected, there is yet a similarity,

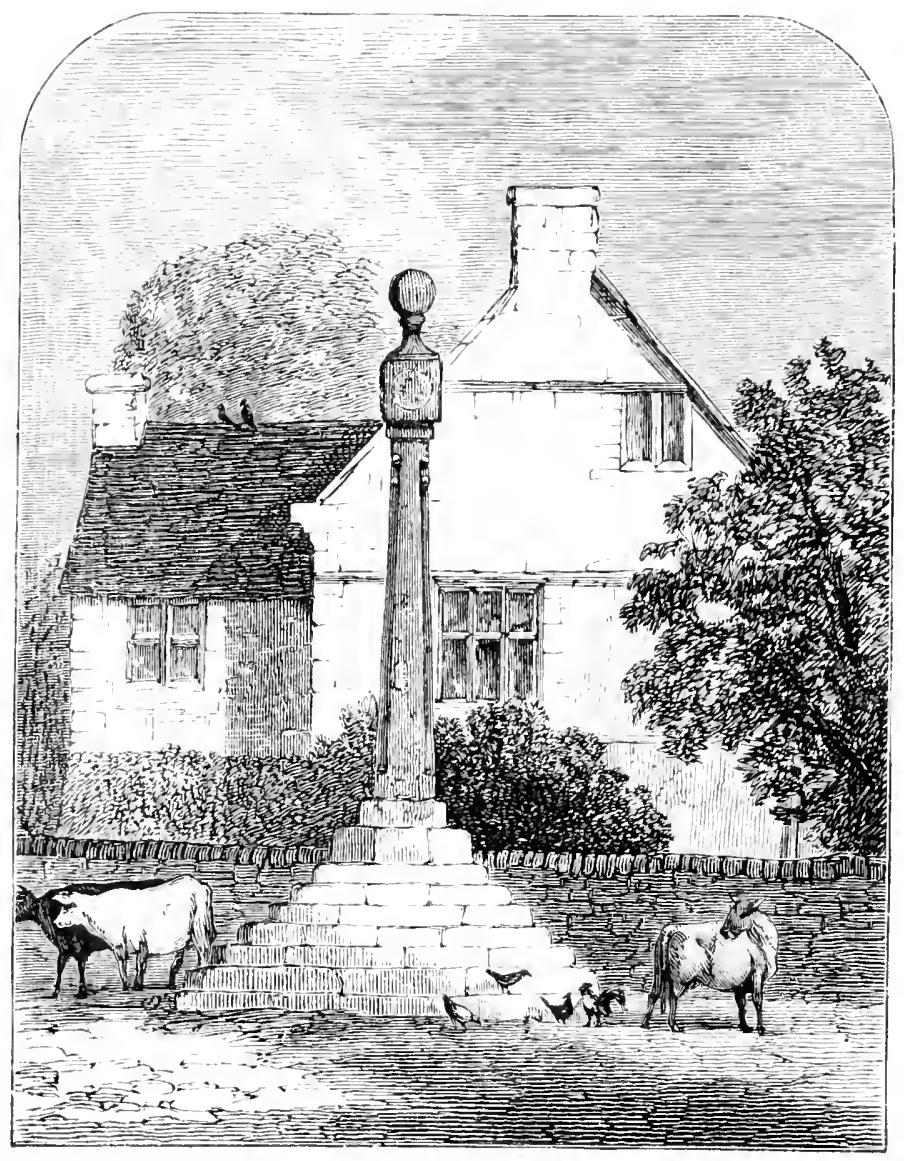

Bromboro Cross,

and in some there is a nondescript character if indeed such a word can be applied to any one branch of their quaint architecture beyond any other part) that would 
almost seem to point to the joint design of northern and southern monks.

Sculptured crosses, and sometimes incised slabs, were placed over the graves of ecclesiastics from very ancient times, and two recent ones, probably about A.D. 1350, which have been brought to light in the restoration of Chester Cathechal, are shown on page 92.

At one time it is said a Runic cross stood in the village of Bromboro, in the hundred of Wirral, in Cheshire; but the only cross that is now standing was built about the year 1 100. It is in a very pleasant English-looking village, on the high road between Liverpool and Chester. One remarkable feature in it is the high flight of steps, all of which have very small treads. The upper portion of the cross has been taken away, and a very unsightly sundial substituted, with a large round ball over it. It is in good repair, and might be restored to something like its original form without great expense. 
VIII.

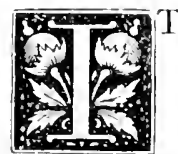

I was not possible to conclude the more ancient forms of crosses in one chapter; indeed, they might be continued almost indefinitely, for in Cornwall, and some parts of Devon and Wales, they are very numerous. The Sandbach crosses seem at first to be curious isolated memorials, and they are all the more interesting from there being so very little that resembles them in that part of England; on this account some very curious Runic crosses which have been discovered at West Kirby are worthy of note. True it is, this place is forty miles away, but in the same county. The class of sculpture, though common in Scotland and Ireland, and not unknown in the Isle of Man, is rare in England, as has already been noticed. It would seem not to be without connecting links, however, for opposite to the West Kirby Cross was Hilbre Island, at the mouth of the Dee, easily approached at low water over the celebrated Dee Sands, that have so often proved fatal to wayfarers when overtaken by the rising tide. On this island, which is now only inhabited by a lighthousekeeper, there was at one time a cell of Cistercian monks in connection with Chester Cathedral; traces of it have been recently discovered. A red sandstone cross of 
Eastern character, with a ribbon moulding, was found here; it appears to be a little later than the one at IVest Kirby. Mr. Eckroyd Smith, speaking of it, says: "The cross is similar in design to several found in Ireland and the Isle of Man, except in its circular border, which closely resembles the Greek mandros, and is of rare occurrence, as we have only been able to discover it, but associated with other details, upon the following crosses, all situate in the Isle of Man, viz., Ballaugh Churchyard, with Runes; Kirkandrew's Green, at the church gates; garden of the Vicarage, Jurby." A sepulchral stone, eviclently of a date anterior to the Norman Conquest, was found on the island, in what was certainly at one time a graveyard; the style corresponds very materially with the cross above described.

The parish of West Kirby is situated in the north-west part of Cheshire, and contained two churches-one the parish-church, and the other a chapel of ease upon St. Hildeburgh's Eye, as it is called in old documents; singularly enough, all mention of it is omitted in Domesday Book; indeed, our information of it is derived from the charters of St. Werburgh, in Chester, and it is from this source that Ormerod principally quotes.

The remains of the Runic cross here engraved were found on the banks of the estuary of the Dee, and were only disembedcted recently, during some repairs to the venerable church. The two fragments formed part of the shaft. Mr. Eckroyd Smith, speaking of this relic, says: "It belongs to a class of sculptured remains which, though of not unfrequent occurrence in Scotland and Ireland, are rare in lingland. Upon each of the four sicles, complete 
or fragmentary, appears a Runic knot or braicl; two of them are so badly chipped that the ornament is hardly recognisable, but their fellows display varieties of the Runic interlacing work of great variety." In Dr. Stuart's excellent book on the "Early Sculptured Stones of Scotland and the North of England," there does not appear to be any stone presenting the varieties of those given here.

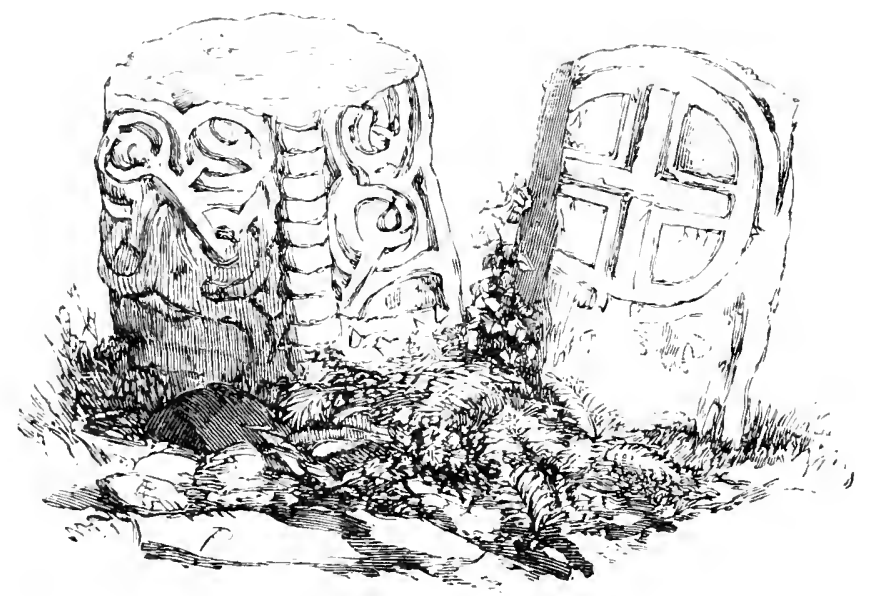

Remains of Runic Cross, West Kirby', Cheshire.

It is not a little singular that in the immediate vicinity of this cross was found a magnesian limestone lintel five and a half feet in length, and sculptured with the same kind of interlaced work as the Christian relic; there is hardly a doubt that these two interesting remains belonged to some old temple of which all record has long since perished.

The late Mr. Gilbert French wrote an elaborate article to show that these twisted Runic designs were simply the 
artempt to imitate in stone the osier-work of our Scandinavian ancestry; but the reasoning is perhaps hardly cogent, though the theory is now commonly adopted. It will be remarked that the angles of these stones are corded, which is uncommon in contemporary remains.

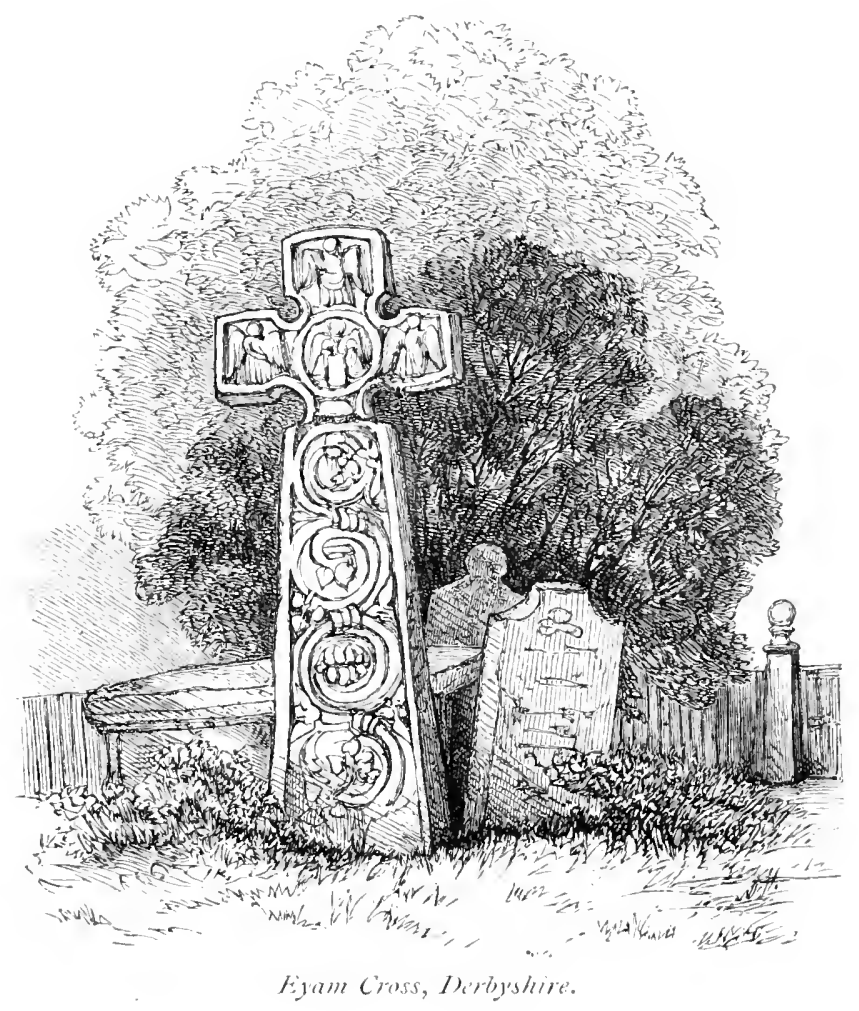

The next example we shall notice is that at Eyam, in Derbyshire, which is an old Saxon cross of excellent proportions, situated in the graveyard of the parish church. It is in a good state of preservation, and, like that of Bakewell, is a very perfect example of the period in which 
it was built. There are fire elegant scrolls cut upon the front of the shaft in relief, and in the middle of these is a trefoiled leaf. A slender spray also is cut over the volute, terminating in a similar trefoiled leafwork. The curves of the foliage bear some resemblance to Roman work, and whatever may be the date, there is no doubt they have been copied from Roman scrolls.

Eyam is a village on the Peak, not very far from Bakewell; and in 1757, in digging a grave near the fine old cross, three out of five men were struck with a remarkable illness, closely resembling the plague of 1666 , and died. The fact led to curious speculation, for this village was attacked by the plague, which was supposed to have been brought from London in a box of clothes. Nompesson, the rector of the parish, deroted himself with great courage to stay its progress. He lies buried only a few feet from the cross. This interesting relic lay in pieces in a corner of the churchyard when John Howard, the philanthropist, had it restored to its present site.

Bakewell Cross strongly resembles Eyam, but the scrollwork is not so graceful; it is also in the churchyard, and is much more ancient than the church, though the latter contains some fine Norman work. The town of Bakewell is delightfully situated in the vale between Matlock and Buxton, and its other attractions orershadow the cross.

Carew Cross, which is situated in a remarkably picturesque part of Pembroke, differs very materially from either of the above-mentioned, and more closely resembles the Eastern relics we have spoken of. The interlaced work is identical with many examples in Ireland, Scotland, and the Isle of Man; its exact counterpart may be 
found in old specimens of metal-work, or carrings from Cairo or Rosetta, also in the interesting ruins of Central America. This cross stands about fourteen feet high, and is a monolith. There are characters upon it which have not hitherto been deciphered.

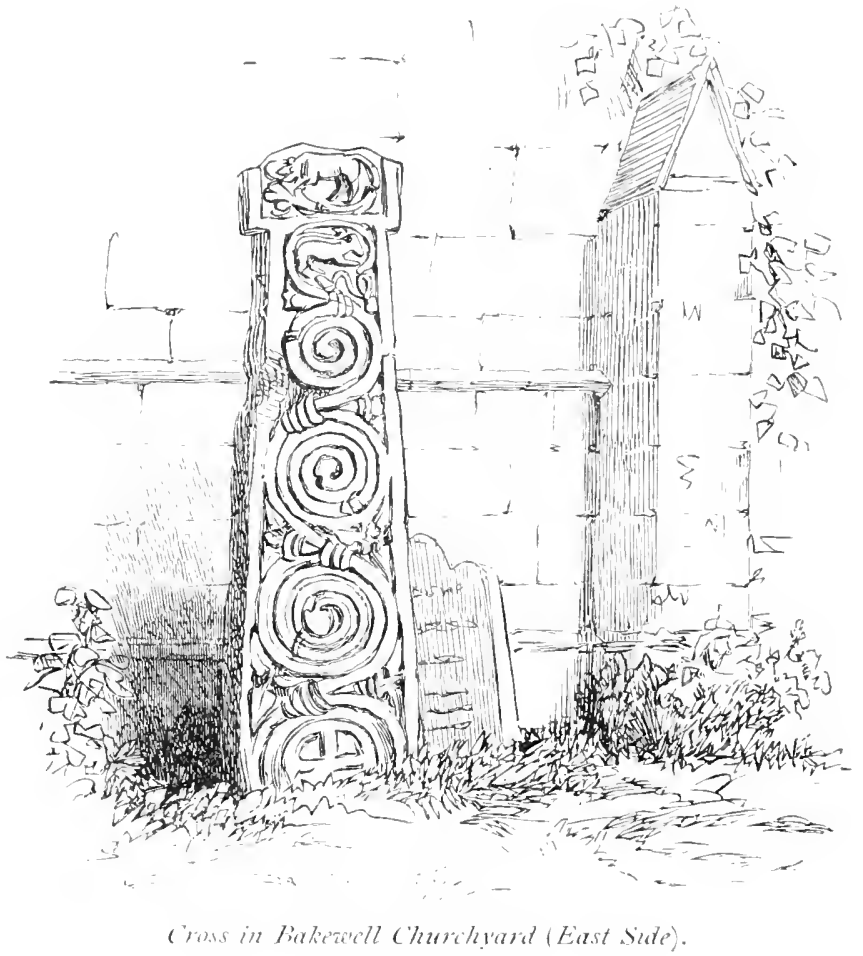

Carew Cross greatly resembles the cross in Nevern churchyard, and indeed all the remarks upon the former would apply to the latter, which forms the sulject of a woodcut. The upper part of the Nevern cross might easily be mistaken for Chinese or Hindostan work, and the lower 
consists of the interlacing common to many half-civilised nations. The date of these two crosses is uncertain.

The crosses in Cornwall are formed of granite or serpentine-trappean rocks that seem to have been formed out of

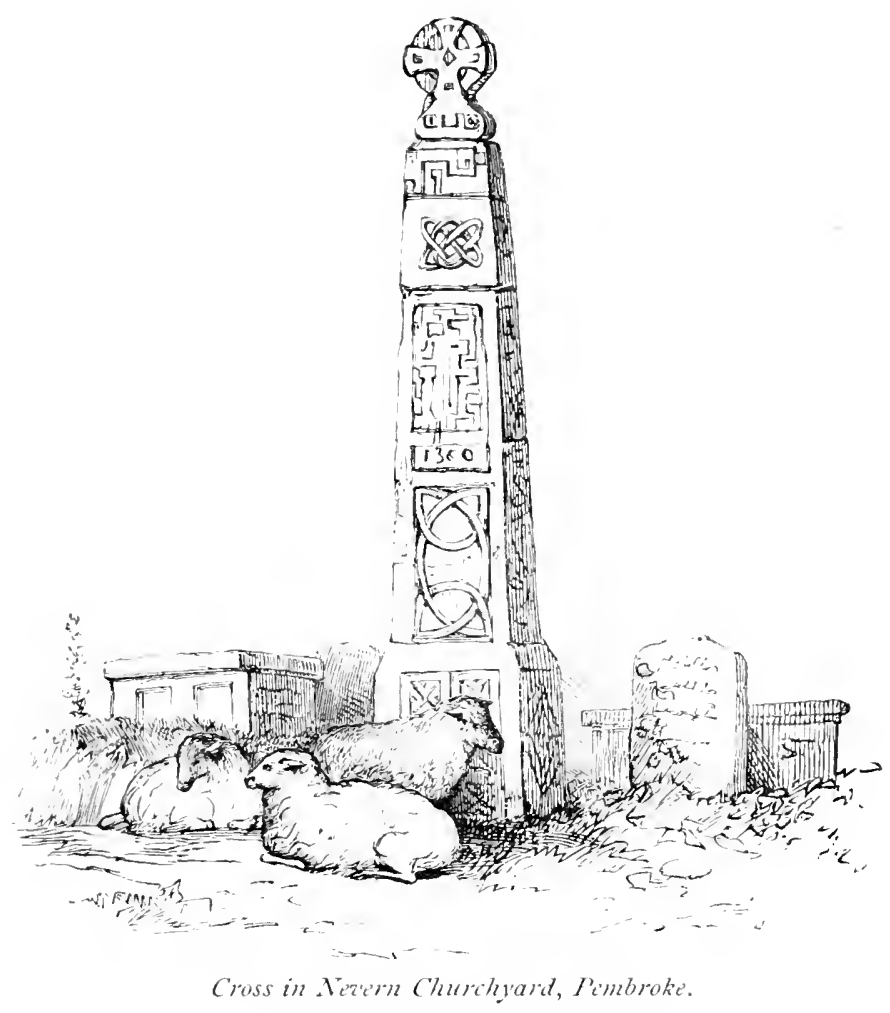

the débris of volcanoes, such as dust and ashes. Most of these rocks are formed under water, are exceedingly hard, and in consequence but little changed.

The Cornish Britons remained separate from the Saxons down to the time of the Norman conquest, when their 
lands were appropriated by the Norman chiefs, though their monuments remained almost undisturbed.

Ilugh de Poyens, the first superior of the Knights Templars, visited England A.D. 1128, and many grants of land were made to that fraternity in the county of Cornwall. At the breaking out of the Crusade the Pope granted the Templars the symbol of martyrdom-the blood-red cross; the Knights of St. John bore a cross of the same form, but of course black and white, and they, as well as the Templars, held lancts in Cornwall, which will account probably for this particular form of cross.

Cornish crosses are very numerous; they are found by the road-sides, in churchyards, and at nearly all old crossroads, though many have been removed. The Puritans seem to have but little troubled this part of England, and the regret is the more that there are so few architectural examples left; for this circumstance, added to the imperishable nature of the material of which they are built, would have preserved them to us. Only two examples are here given, though they might be multiplied indefinitely. One of these is the well-known Four-hole Cross, and the other is from Forraberry.

An excellent representation of Llanhorne Cross appears in Blight's "Cornish Antiquities." This is a Runic cross, and is a specimen of a small class which may be seen in a few parts of Cornwall and Deronshire.

St. Mawgan's Cross, given on p. 104 ; is very elaborate; and there is a legend that has not yet been satisfactorily deciphered. The tabemacle part of this cross consists of a representation of the Crucifixion on one side, and figures of saints on the others; it woull almost seem to stand on 
a shaft that has at some time been shortened. The base on which it rests is eviclently one of the old Cornish pedestals. The age of this tabernacle is about five hundred years.

In Blight's "Cornwall" there is a drawing of Llanteglos Cross, a curious feature of which is that the enrichments are let in with different coloured stone. This cross was
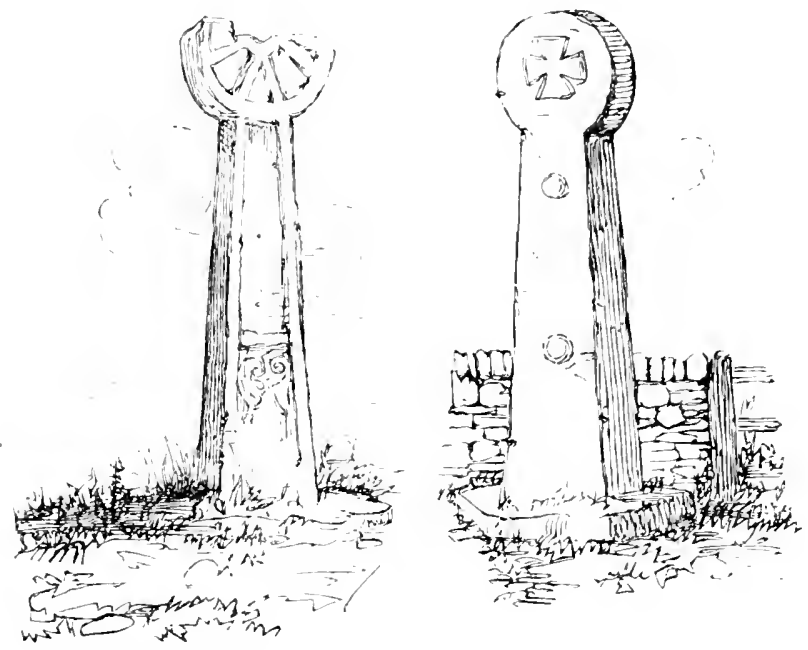

Cornish crosses.

Fourhole Cross.

Forrabery.

found in a trench that ran rouncl the old church, and was re-erected on its present site. There are two canopied niches on the broadest sides with the usual Virgin and Child, and also the Crucifixion; and on the narrower sides are the figures of St. Peter and St. Paul.

Cornwall abounds with interesting, though not picturesque, monuments of early Christianity. At St. Roche, on a wild and almost inaccessible rock, is a recluse's cell, 


\section{IO+ ANCIENT STOVE CROSSES OF ENGLATD.}

and the remains of a cross, which are very difficult indeed to reach. Such places are doubtless the cells of recluses who have made up their minds to live in spots the most difficult of access, in order to devote themselves more undisturbedly to their meditations. In some places crosses have been let into old stone walls, and are hardly to be noticed by an ordinary passer-by.

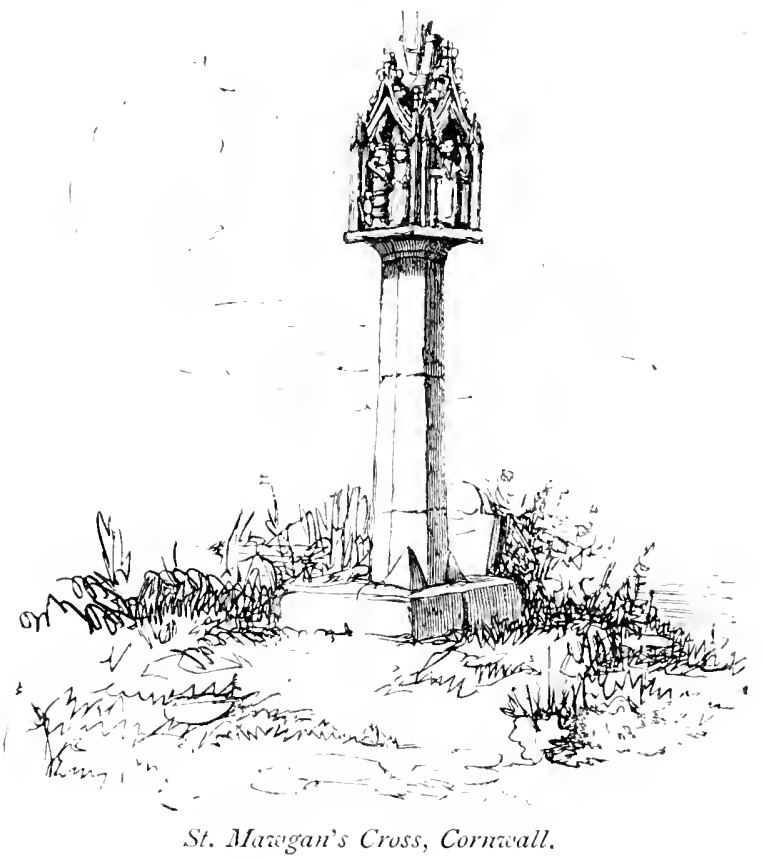

To a very early period indeed belongs the cross known as Sueno Pillar, near Forres, Elgin. It is a most remarkable block of granite, of which no history is left; but it so closely resembles the stones of Nineveh that it might well be mistaken for a relic from that country. This great strone is twenty feet high and nearly four feet at the base; 
and in confirmation of the conjectures which have been hazarded as to the Eastern character of this and other ancient sculptures in our land, it is curious to remark that on the top of this great pillar is the figure of an elephant. The sculptures are cut in a most singular manner: there are men and horses in military array, and in warlike attitude; some seem to be holding up their shields in exultation, and others are joining hands in friendship, or as some token of fidelity. Then there is a fight and a massacre of the prisoners, and the clead are laid in perfect order, just as is seen on Asiatic sculptures of great antiquity. The arrangement of the men also, and of the knights, seems to be pretty conclusive that the figures do not represent any tribes that inhabited those parts at the time it was erected. On the other sicle of this remarkable monument is a large cross with persons apparently in authority in conference. It has been held that all this represents a scene in Scottish history, and is the expulsion from Scotland of some Scandinavians who had long infested the northern parts, about the promontory of Burghead, and had.lived on "the fat of the land;" but this is hardly a tenable theory. The name Sueno which the cross bears is also saicl to be that of a king of Norway who made peace with Malcolm II., King of Scotland. The cross, however, denotes a Christian period, and as such we can have no hesitation in introducing it. 
$1 \mathrm{X}$.

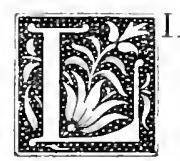

KE the common opinion that Shakspere has only been recently appreciated, and was of no account in his own times, is the idea that English architecture has only just now been valued at its proper worth. It is of no avail, apparently, that these errors are extinguished to-day, they revive to-morrow. There can be no doubt that numbers of educated men saw with dismay the destruction of crosses and other ancient monuments; so that, in fact, the real appreciation of the excellences of English art never quite died out. In Gloucestershire, Wiltshire, and Somersetshire, there are not fewer than two hundred crosses and remains of crosses. Most probably the examples given comprise all the more remarkable of them, but it is with satisfaction we see so large a number partially, at least, preserved.

A curious dialogue, written by Henry Peacham, between the crosses of Charing and Cheap, describes them as "fearing their fall in these uncertaine times," which, indeed, was only two years before the general order was issued for the destruction of crosses. There is a curious recipe for marble cement in it: Charing Cross is made to say, "I a m all of white marble (which is not perceived of every one), 
and so cemented with mortar made of the purest lime, Callis sand, whites of eggs, and the strongest wort, that I defy all hatchets and hammers whatsoever." Still, at the destruction of monasteries, when such glories of architecture were destroyed, it was not likely that Charing Cross, with its white marble, should escape coretous eyes: "In Henry VIII. time I was begged, and should have been degraded for that I had; then in Elward the Sixe, when Somerset House was building, I was in danger; after that, in the reign of Queen Elizabeth, one of her footmen had like to have run away with me; but the greatest danger of all I was in, when I quaked for fear, was in the reign of King James, for I was eight times begged:part of me was bespoken to make a kitchen chimney for a chefe constable in Shoreditch; an inn-keeper in Holborn had bargained for as much of me as would make two troughs, one to stand under a pumpe to water his guests' horses, the other to give his swine their meate in; the rest of my poore carcase should have been carried I know not whither to the repaire of a decayed old stone bridge (as I am told) on the top of Harrow Hill. Our royal forefather and founder, you know, King Edward the First, built our sister crosses-Lincolne, Granthame; Woborne, Northampton, Stonie Stratford, Dunstable, Saint Albans, and ourselves here in London, in the 21 st year of his reigne, in the year 1289." The omission in this list of Waltham Cross, the last before the procession reached London, is curious.

The plaintive recollections of Cheapside Cross are exceerlingly valuable, as they show that reverence for antiquity was strong in the time of Elizabeth; indeed, the 
intemperate zeal exhibited in destroying carred work only culminated in the century after she began to reign. Cheapside Cross is made to say :-

"After this most valuable and excellent king had built me in forme, answerable in beauty and proportion to the rest, I fell to decay, at which time John Hatherly, maior of London, having first obtained a license of King Ilenry the sixt, anno $1+f 1$, I was repaired in a beautiful manner. John Fisher, a mercer, after that gave 600 marks to my new erecting or building, which was finished anno 1484; and after, in the second year of Henry the Eight, I was gilded over against the coming in of Charles the Fift. Emperor; and newly then gilded against the coronation of King Edward the Sixt.; and gilded againe anno 1554 , against the coronation of King Philip. Lord how often have I been presented by juries of the quest for incumberance of the street and hindring of cartes and carriages, yet I have kept my standing: I shall never forget how, upon the 21 st of June, anno 1581, my lower statues were in the night pulled and rent down, as in the resurrection of Christ, the image of the Virgin Mary, Edward the Confessor, and the rest. Then arose many divisions and new sects formerly unheard of, as Martin Marprelate, alias Pewin, Browne, and sunclry others, as the Chronicle will inform you. My crosse should have been taken quite away, and a Piramid erected in the place, but Queen Elizabeth (that Queen of blessed memory) commanded some of her privie councill, in her Majesties name, to write unto Sir Nicholas Morely, then maior, to have me again repaired with a crosse: yet for all this I stood bare for a yeare or two after. Her Highness being very angry, 
sent expresse worde she would not endure their contemp, but expressly commanded the cross to be set up, and sent a strict command to Sir William Rider, Lord Maior, and bade him respect my antiquity," \&c.

The above is a graphic, and no doubt very accurate, description of the treatment of ancient monuments in the past without iconoclastic decrees. At the present time, even, venerable half-timbered structures are remorselessly demolished to make way for new premises. It seems very disgraceful that buildings which have stood for centuries, and are still in good condition, should be sacrificed to so-called modern improvements. In most instances they might be adapted, without much difficulty, to the mercantile exigences of the times; at any rate, space might be found without destroying the now-diminishing number of ancient remains. There can be no doubt that the discussion of this subject will assist the hands of the Government Commission appointed to protect monumental antiquities, and possibly enable them to embrace a wider range in their excellent work.

Cheddar is situated in a deep gorge of the Mendip hills, and is not surpassed in beauty of situation by any village in England. The "Parliamentary Gazetteer" thus describes it:-“"The ravine is narrow, and the cliffs on each side ascend abruptly to the height of many hundred feet. Some portions of the Chedlar cliffs remind one of a lofty Gothic structure, the action of the elements having worn the rock into niches and columns; and the lofty summits of stone, without much exercise of imagination, seem to assume the appearance of turrets and spires. Immense numbers of jackdaws are constantly flying about the 
middle and upper sections of the cliffs; hawks too of various kinds make their acries in these rocky fastnesses; and the visitor to this sublime scenery may constantly witness them sailing on steady wing in mid-air in all the

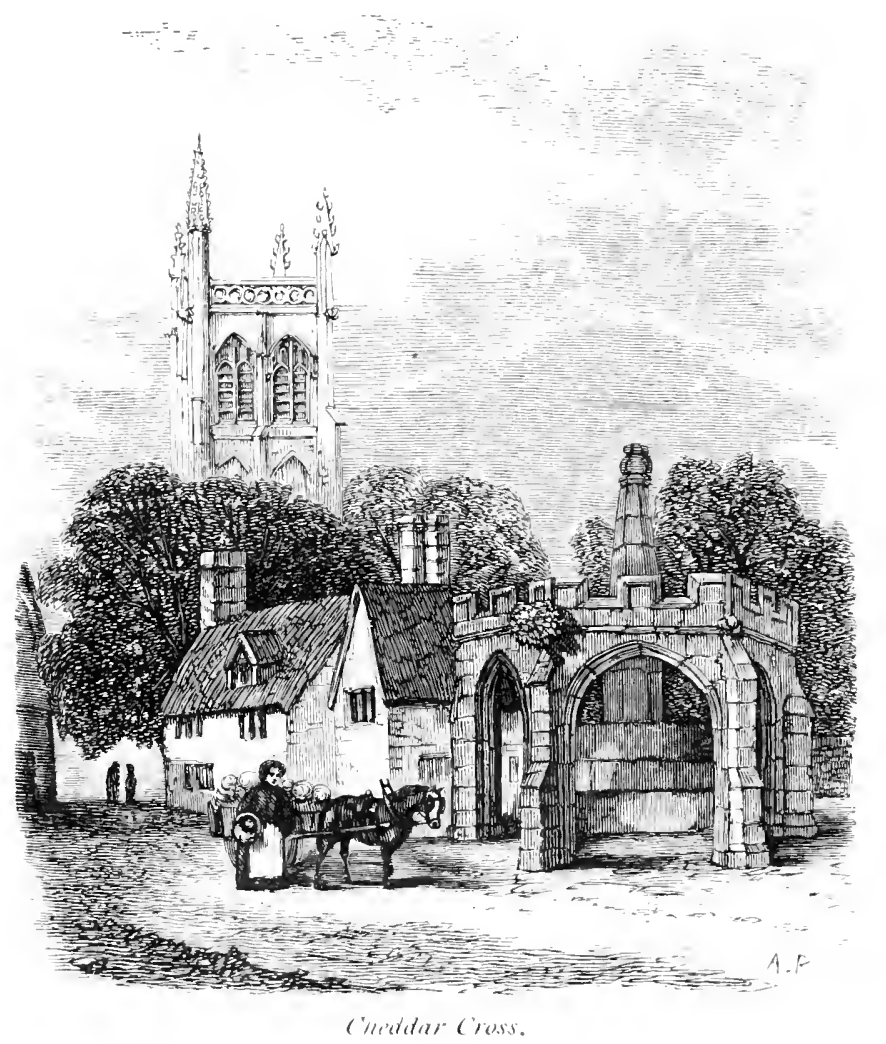

security of an uninhabited region." The church, shown in the engraving, is supposed to have been built about 1 foo, and has a sculptured stone pulpit. The cross is a curious instance of altered design.

It will be noticed, on reference to the plan, that it was 
at first intended to build a hexagonal structurc, and the steps are cut in that form; but on arriving at the top one, from which the cross springs, the designer fitted in an octagon base, and that too not perlaps in a very artistic manner. The general appearance of the cross, however, is picturesque, though it has no architectural attractions to recommend it. Formerly it was simply a village high-
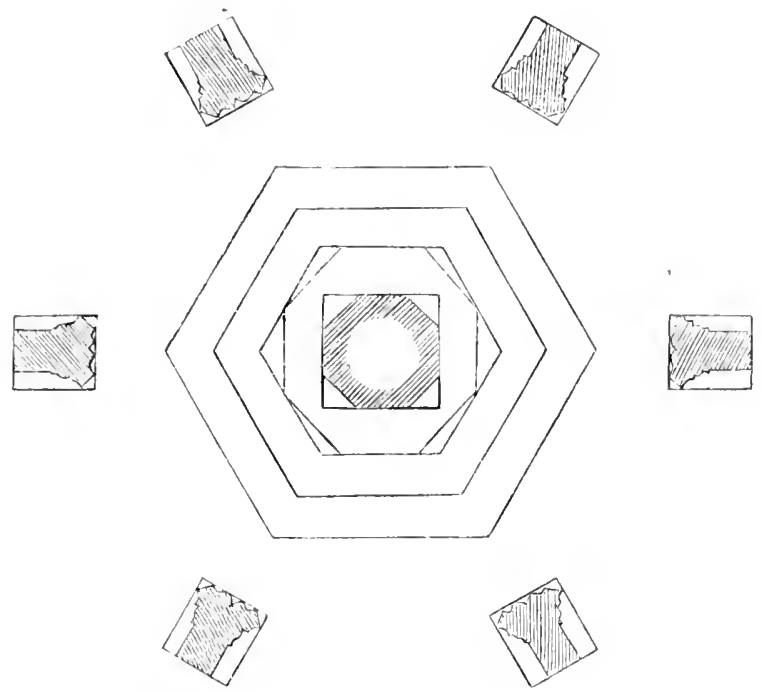

Plan of Cheddar Cross.

cross, like many others; it is on record that it was surmounted with a large tabernacle, in which were figures.

Round Cheddar Cross a heary stone canopy has been built, apparently in the reign of Ilenry VIII. A curious feature in this addition is its scantiness, for there is only one foot between the piers of the canopy and the steps of the cross. The smalness of the accommodation woukd seem to indicate that it must have been a preaching-cross, 
for not a dozen market-baskets could find shelter beneath it. From its steps on summer evenings, notwithstanding its proximity to the church, the preacher would doubtless frequently address a congregation and lead the hymn. The cross stands at the junction of three roads, at the entrance to the village. With every desire to appreciate the merits of ancient design, one is compellect to admit that the structure is more interesting and curious than beautiful. Britton thus speaks of it in his somewhat rare work on the "Antiquities of England:"-

"This shattered cross at Cheddar seems to have been constructed at two different periods, as the central column constitutes one of those crosses that had merely a single shaft raised on steps. The lateral piers, with the roof, were probably erected at a later period, to shelter those persons who frequented the market. Bishop Joceline obtained a charter from Henry III., I gth year of his reign, to hold a weekly market here; but this has been discontinued some years. The present cross is of a hexagonal shape, las an embattled parapet, and the upper portion is ornamented with a sort of sculptured bandage."

a Although there may be something rather disappointing about Cheddar Cross when its great fame is considered, we ought to be only too grateful for its preservation. At Chipping Camplen, in the northern part of Gloucestershire, is a somewhat similar structure, built apparently about the same time. It stands in a picturesque old English town, formerly of some note in the county, but now almost in decay. The word Chipping-from the Anglo-Saxon word ceafern, to buy-mostly indicates a place of merchandise, 
which would necessarily have a market-place and cross. Chipping Campden was a great mart for wool.

The town of Shepton-Mallet is situated about twelve miles to the east of Cheddar. Wells lies between them, and is one of the most perfect examples of an ancient city in England. The Bishop's Palace is moated, with a drawbridge, and is a fine example of an old English castellated building. Three wells overflow in the grounds and form a little lake, which is surrounded with very beautiful trees; over these rise the grey towers and pinnacles of the cathedral, built apparently in the middle of the thirteenth century; the whole being mirrored in the lake below. Perhaps there is no more impressive scene in England. IIere Bishop Ken wrote the Morning and Evening Hymns.

Shepton-Mallet Cross is a remarkably fine structure, as will be seen from the engraving, and, like Cheddar, it has been built round a high-cross of earlier style. It is well situated in the market-place, and is certainly the most striking cross remaining in England, excepting perhaps Chichester, to which in some respects it is superior. It was built in the year 1505, by Walter Buckland and Agnes his wife. The original intention seems to have been to erect a high-cross, somewhat like those at Gloucester and Bristol, but it appears to have occurred that its utility might be increased by a canopy for shelter. Leading from the market-place is a narrow street, with substantial houses and shops, which opens up a fine view of the Mendip Hills. Many celebrated characters have been born in Shepton-Mallet, among others Simon Browne, a dissenting minister, who wrote against Tindal, and was born in 1680 . He was a man of very great learning; but some 


\section{IH ANCIENT STONE CROSSES OF ENGLAND.}

years before his death, in 1732 , he entertained and expounded the curious idea that he had no rational soul, but was merely an unconscious atom. Perhaps lis contemporaries have unfairly stated his views, but such they are

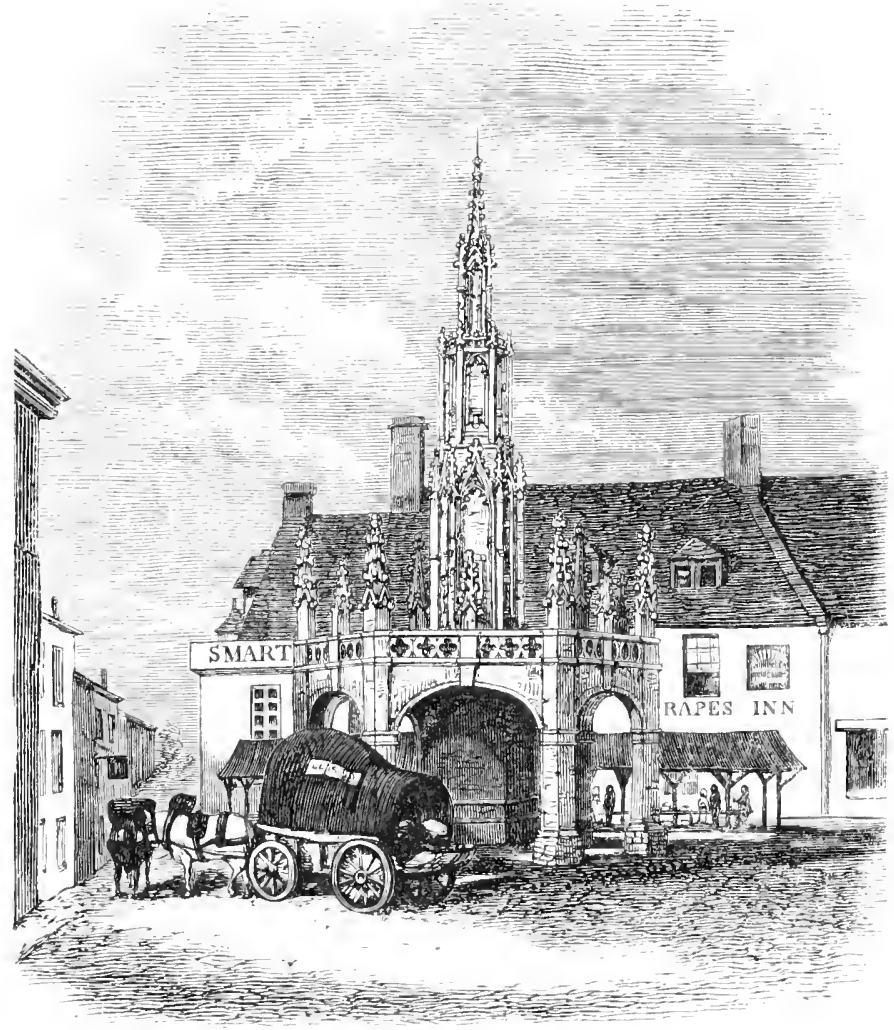

Sheptrum-lallet cioss.

saicl to be. Ilis memory is yet fresh in those parts, and so also are some of his curious ideas. He never would say grace before dinner, unless very much pressed, because he said it was expecting a miracle. 
Glastonbury is one of the few towns in England that have preserved an ancient character, even in spite of many and destructive changes; like Malmesbury, the grand old monastic buildings have quite incorporated themselves in the houses of the town, and, happily, much of the old monastic architecture remains. Here, as tradition tells us, Joseph of Arimathea rested on his way to preach the gospel to the British, and while wearied in his ascent of the hill he drove his staff into the ground, which is said to have taken root and ever since to blossom at Christmas time-at least, so say the guide-books. It is beyond doubt that a very fine old thorn does grow there, and probably it blooms early, which, from my own knowledge, is all I can affirm.

Glastonbury Old Cross was a quaint, though perhaps not very pleasing structure. Until a comparatively recent date it was in a good state of preservation, and harmonised extremely well with its surroundings. The whole town is a series of old associations, and it may not be out of place to quote a description of it from the pen of a local antiquary:- "We have hardly left behind us the flats that surround and nearly insulate the town (whence the old British name of Glassy Island), and ascend the eminence upon which it stands, before we perceive that almost every other building has either been constructed in modern times, quarried from the stone of the ruins, or is a direct remain of the architecture of the monastery from whence it is derived. The George Inn is not one of these; it preserves its old character; it was from the earliest times a house of accommodation for the pilgrims and others visiting Glastonbury." 
This old cross is so curious and so singular in the distribution of its gables that a sketch is here given. Britton says, "Glastonbury Cross, though a large and extremely curious structure, is hardly noticed in the topo-

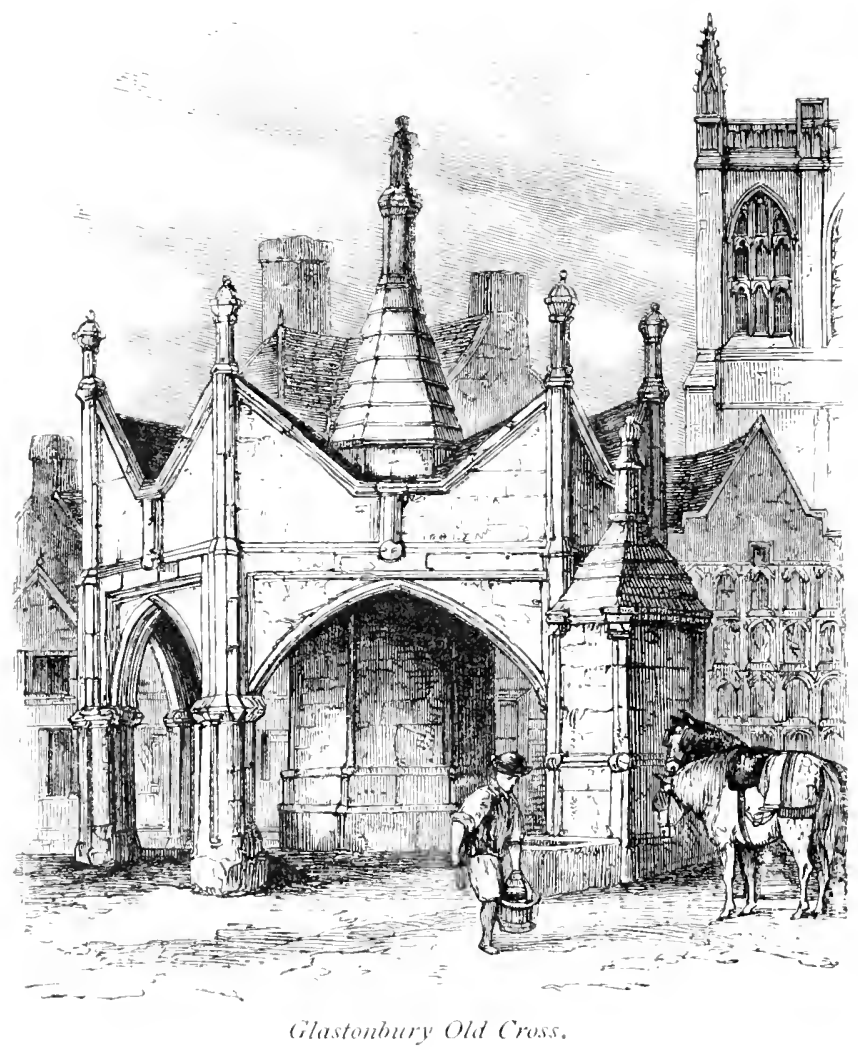

graphic annals of this county; its history is therefore perhaps entirely lost." Unfortunately, the building itself also is now lost, for after Britton wrote it fell into decay and neglect, and many stones were carried away for modern edifices. "There is something peculiarly unique," 
he adds, " in the shape and ormaments of the building. A

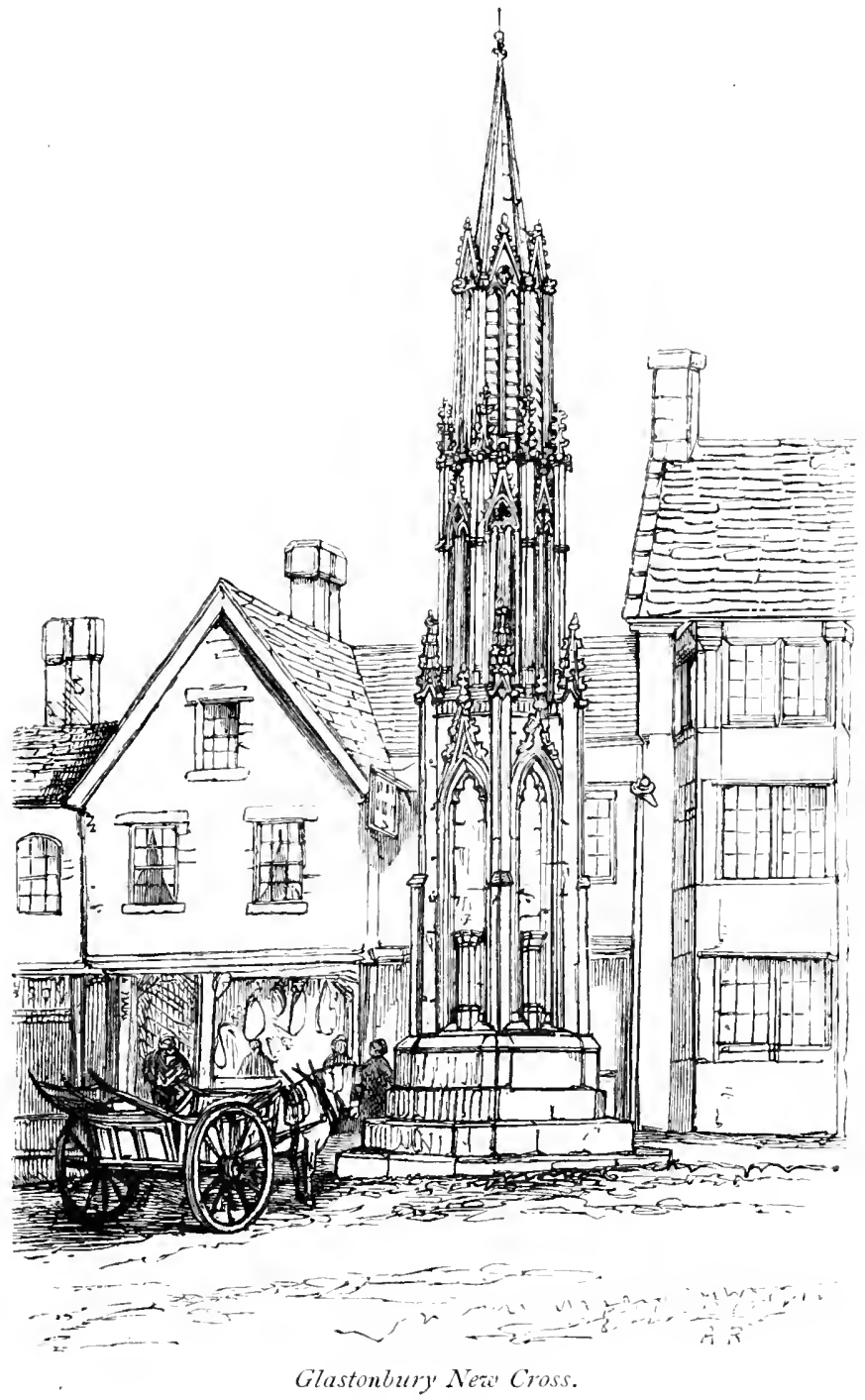

large column in the centre, running through the roof, and terminated with a naked figure, clustered columns at each 
angle, with odd capitals, bases, \&c., and pinnacles of unusual shape, all unite to constitute this one of the eccentricities of ancient building. From the time of the Norman Conquest to the dissolution of English monasteries, the varied and progressive styles of architecture are satisfactorily defined, and a very general uniformity prevails in all the buildings of a particular period; but the specimen before us differs from any example I ever met with. Hearne, in his 'History of Glastonbury,' Camden, Willis, and Stevens, are all silent regarding this building." There was a mutilated inscription, dated 1604 , upon it, and also a shield with the arms of Richard Beere, the last abbot but one, who died in 1524 ; it would almost seem that an inveterate spirit of punning had even reached the sacred precincts of the armorial bearings, for, in allusion to his name, as would seem, there are two cups with a cross between. There was a conduit at one corner with a trough, and this aclded greatly to the picturesqueness of the scene.

The present Glastonbury Cross is not unlike the copy of the ancient Bristol high-cross at Stour Head, or the demolished one at Gloucester, both of which will form the subjects of the next chapter. Statues are wanting to complete the outline, but the structure is pleasing, and it is well situated. 


\section{X.}

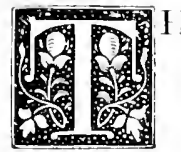

11: history of Bristol high-cro is is interesting and somewhat sad. It was built in 1373 , according to some accounts, and according to others in $12+7$. A passage in a MIS. calendar thus refers to it:- "Anno 1247. Now that the bridges went happily forward, the townsmen on this side of Avon and those of Redcliffe were incorporated, and became one town, which before was two, and the two places of market brought to one, viz., that at Redcliffe side being kept at Temple Cross, or Stallege Cross, and also that from the old market near Lawford's Gate, both being made one, were kept where now it is, and a faire cross there built, viz., the High Cross, which is beautiful with the statues of several of our kings." Mr. Poole, in an excellent little work on Bristol Cross, says: "It is difficult to account for this discrepancy of dates otherwise than by supposing that either the calendars are not trustworthy records (and the fact that the pen of Chatterton was known to touch some of them renders their unqualified acceptance as historical documents anything but easy), or else the rebuilding of the cross in 1373 consisted in certain additions and embellishments, the rest of the high cross, with the statues of the kings, remaining as it was before." One thing, how- 
ever, is certain-the architecture of the present cross belongs to the period last named, and probably it was a totally new structure at that time. Originally this cross was richly coloured, the colours consisting of blue, gold, and vermilion. It was built of a coarse-grained oolite, very liable to absorb moisture, but the polychromatic colouring preserved it for centuries. A lesson on the restoration of churches might be gathered from this fact; many fine old walls that are re-cased might be allowed to stand, if a proper colourless solution were applied to bind up the crumbling particles. It is in the nature of oolite and sandstone to disintegrate, and this process might be stopped.

Bristol Cross consisted of a series of niches with canopies of great beauty, which formerly contained statues of English kings; in 1633 the citizens raised the cross in the same style of architecture, and arded the statues of three more kings and Queen Elizabeth. The cross was also enclosed in an iron railing, and repainted and gilded; but evil days were before it.

In 1733 a silversmith who lived near it made affidavit that in every high wind this old structure-which might have lasted for centuries if left alone-rocked so much that his house and his own valuable life were in danger if the cross fell towards him; so he procured its removal, and it was thrown into the Guildhall as a thing of no importance, where it lay for a long time, until Alderman Price and a few gentlemen had it re-erected on College Green, opposite the cathedral. Here it remained for some thirty years, until a Mr. Campion, a gentleman apparently of great public spirit, discovered that it stood 
in the way of a walk, and opened a subscription list to lave it removed! The cross was again rudely pulled down and thrown into a corner of the cathedral, until

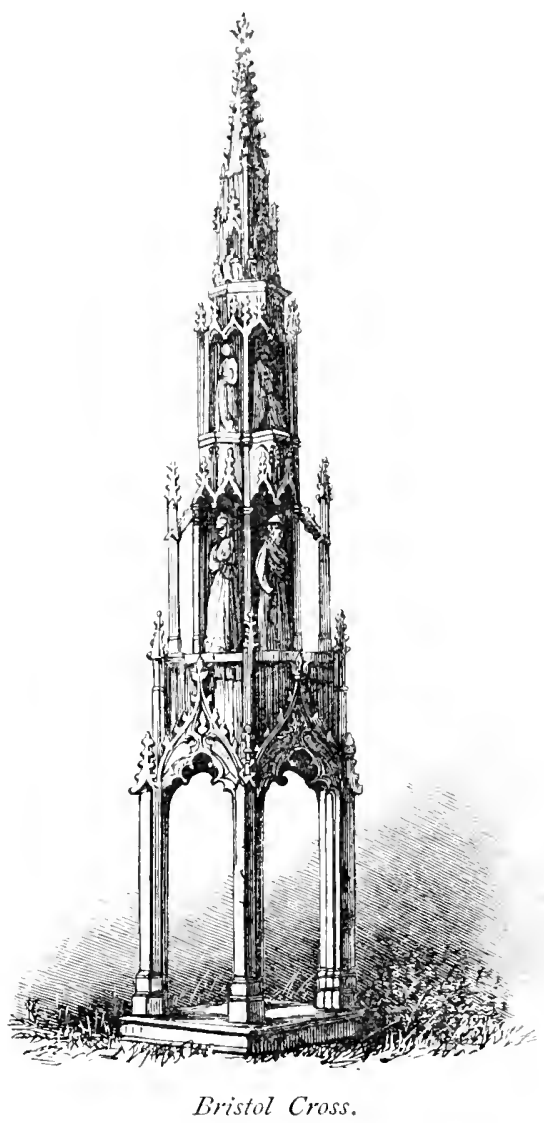

Dean Barton gave it to Sir Richard Colt Hoare, who erected it most appreciatively in his park at Stour IJead.

Bristol New Cross is a copy of the old one, excepting that the upper part is divested of the Carolian ornaments, 
which gives it an incongruous appearance; the canopy also seems rather too high for the rest of the structure. The remarks of Mr. Norton, the architect, on the completion of the structure, are very sensible, in alluding to the absence of sculptured figures. "Leaving out of the question," he says, "the public duty to replace these statues, I must point out to you resthetically how peculiarly unmeaning the structure now is. I know no work of architecture so specially needing the aid of the sister art of sculpture. The addition of the figures can alone produce harmony of general effect; and with these, both the architectural shell and the canopied statues, would communicate to each other a borrowed aid, and thus vivify that which is now a tame and insipid work."

We have just recorded the vicissitudes in the history of Bristol Cross, unhappily a sadder fate awaited the sistercross of Gloucester: an act was passed in 1749 for taking down some buildings, and enlarging the streets of the city; as this cross stood on a site which the corporation of the period desired, a decree went forth to demolish it, and it was pulled down so lately as 1750 . There is not, as far as we could learn, any record of the uses to which the fragments were appropriated, every trace has gone; and yet the cross was demolished but within thirteen years of the birth of the accomplished Lysons, to whom antiquarians in England owe so much; it was situated within two miles of his family-seat.

Gloucester Cross-in a note on a very excellent print by Vertue-is said to have been erected in the reign of Richard III., and his statue was among those demolished; but it is probably older: the style of canopy, as far as it 
can be gathered from Vertue's print, belongs to the reign of Edward 11l. There were also statues of earlier kings

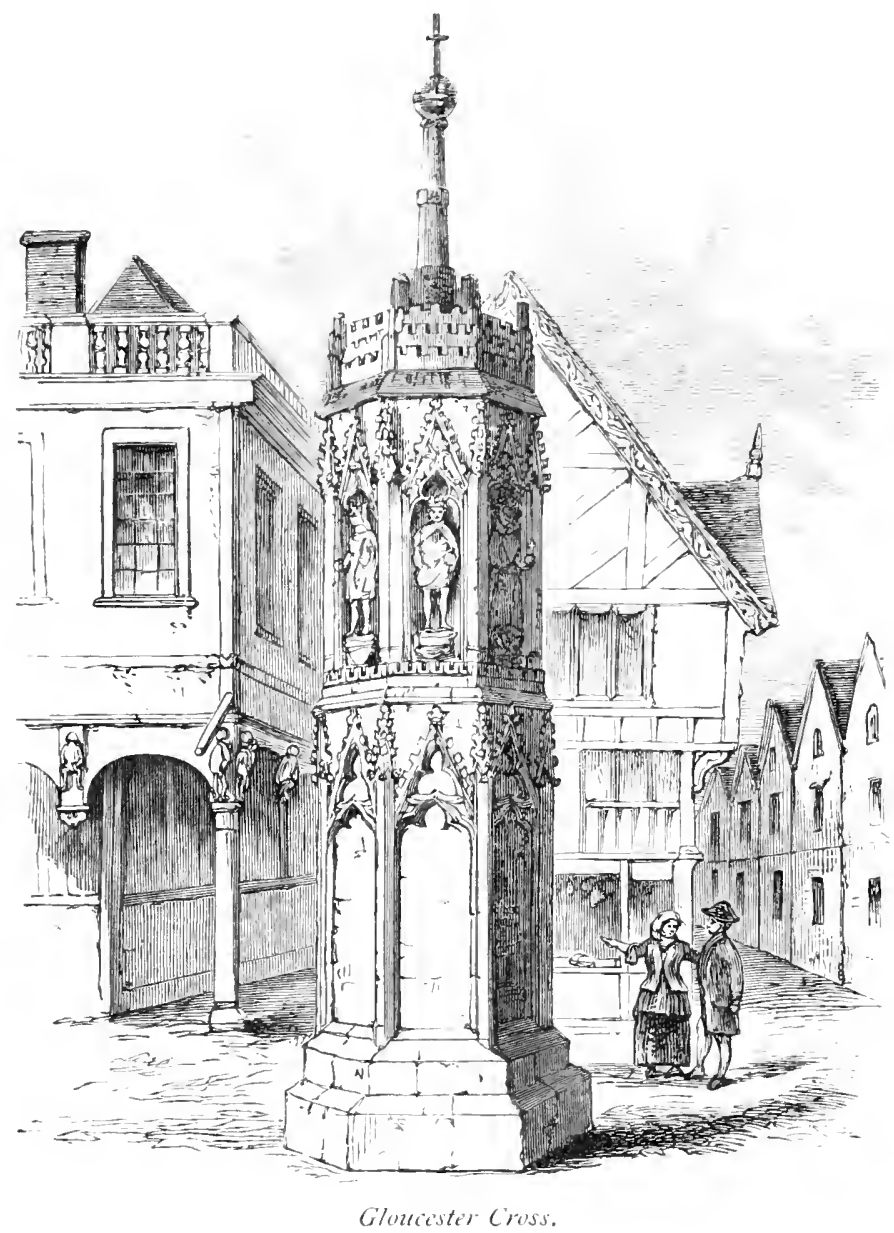

than Richard III., viz. John, Richard II., Henry III., and Edward III. These figures were, as far as can be judged from the old print, very excellent works of art, and it is 
surprising that even they were not preserved. The houses round the cross were good specimens of ancient clomestic architecture, and much resembled the older ones now standing in Chester. The statue of Richard III. would have been very interesting had it been preserved; and, perhaps, it would have solved some of the theories as to his physical deformity or otherwise: according to the excellent print from which this is taken, his figure is rather short than misshapen. The pedestals on which the monarchs are standing have evidently been much misrepresented in the engraving by Vertue, which is, generally speaking, a very excellent work of art; they have been drawn as though they were rough uncut stones, but in all probability they were fine old carved corbels that had become weatherworn out of all sort of recognition.

Of course the upper part of the cross is modern, not older than Charles I., and there were formerly the inevitable little flags on slight iron stems, that look so very meagre, and are seen in the prints of Coventry Cross, and others that have been restored since the Reformation. Besides the kings there were statues of Queen Eleanor and Queen Elizabeth. The latter, and that of Charles I., were probably erected in the place of some others that had fallen into decay. The height of this cross, as measured by Mr. Thomas Ricketts, to whom we are indebted for the sketch from which the engraving by Vertue is taken, was $3+$ feet 6 inches; but probably, or indeed certainly, there was another story, which, with the spiral termination, would have made its height some 50 feet.

From the steps of both these crosses all proclamations were read to the people. Bristol Cross was situated in 
Iligh Street, and Gloucester Cross at the junction of Southgate Street, Northgate Street, and Westgate Street.

Oakley Grove, near Cirencester, is the beautiful seat of the Earls Bathurst; the mansion is only a short clistance from the town, and bears obvious marks of the architecture which prevailed during the early reign of the Ilouse of Hanover. In the park is the celebrated market-cross of Cirencester, which stood in the lesser market-place. On the base is some ornamental panelling; the shaft is octangular and about iz feet high; round the capital were four shields of arms, now nearly obliterated. There are two steps and a fine square base to this cross. Each side of the base has four trefoiled panels, with quatrefoils over. The shaft rises abruptly from the base, and is well proportioned, though it may have been originally somewhat higher.

Cirencester Cross is probably the successor of a much more ancient one, or perhaps more than one. The town itself is full of interest; many ancient Roman statuettes have been found in subsoil ploughing in the neighbourhood. A rather amusing story is told by Camcen. In the year 1731 a fine bronze was found near the cross, and the workman who discovered it parted with it to a gentleman who was to pay according to the ralue he received for it: he gave the finder $f_{20}$, but he himself had managed to realise $£ 150$. It was of course well sold at this sum, and the finder in receiving his $£ 20$ did probably much better than he could have otherwise done, but he looked upon himself as badly treated. The bronze was a Cupicl, weighing about i I lbs.; the eyes were of silver, but the pupils were gone, and the discoverer had the ground carefully 
sifted over and over again for these, as he was perfectly sure they were diamonds; unfortunately, however, his first treasure-trove was his last.

Cirencester is in the middle of one of the most interesting parts of England, and perhaps one of the most

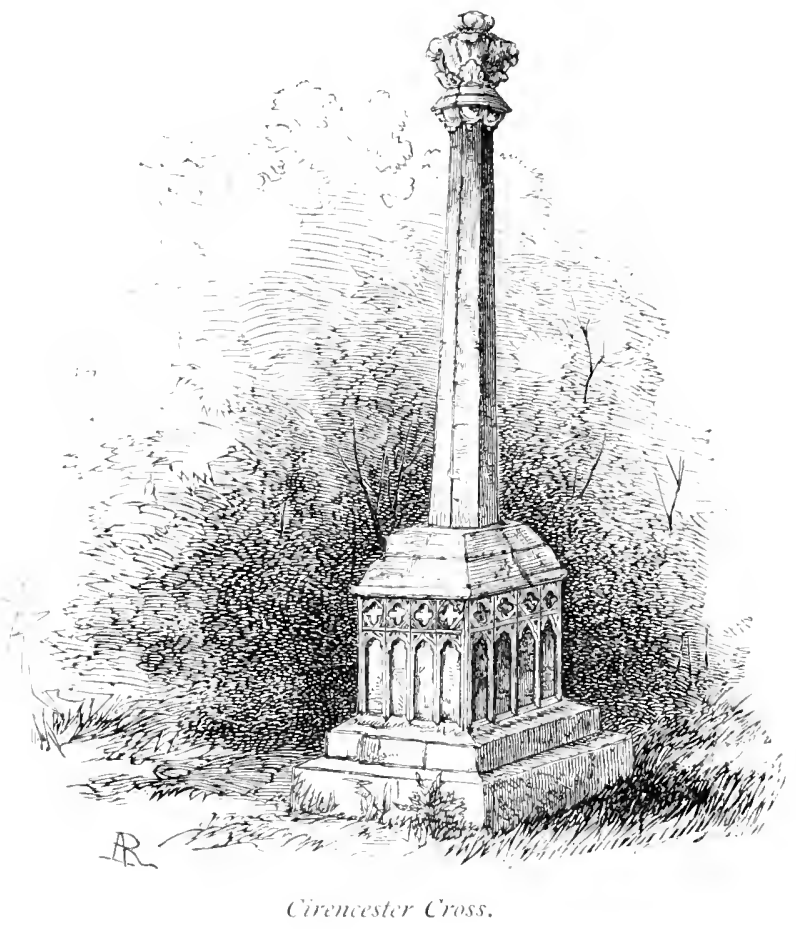

beautiful ; there are also remains, or at any rate traditions, of so many splendicl crosses as would now astonish us could we only see them as they were. The wealth of design and the beautiful forms that have been lost to us when these relics were destroyed will never be known. There are crosses sill standing near the town, at Ashton 
Keynes, Cricklade, and various other places; of some of these engravings will hereafter be given, and some only described.

Not far from Cirencester is Ampney Crucis; it is situated on the Fairford road, about two miles from the town. The cross is in the churchyard, and has some very pleasing features. The tabernacle at the top part is more solid than usual, and there is a kind of dog-kennel roof on a slight curve. The shaft rises octagonally and very boldly from two large square steps and a set-off. This was probably an example of the "weeping-cross," or place to which penitents resorted to bemoan over their shortcomings. This is not apparently a very uncommon or even very uncongenial pursuit with many devotees; for up to the present day Jews go evcry week to the walls of the Temple, and lament over its destruction. It is almost impossible not to connect these weeping-crosses in some way with old Jewish customs; there are many of them still left in England, and the name clings to them. One thing is certain, that the old habits of weeping and wailing date much earlier than the clestruction of the Temple. The lamentations of Jeremiah fully attest this :"The ways of Zion do mourn because none come to her solemn feasts; her priests sigh, and she is in bitterness." Again, "Mine eye trickleth down without intermission," \&c. "A voice of crying shall be from Horonaim, spoiling, and great destruction. Moab is destroyed; her little ones have caused a cry to be heard:" many other passages occur all through the prophets in the Old Testament. Probably more appropriate ones might be found, but these surely express a recognition of public lamentation, and 
almost an encouragement of it, that perhaps may appear strange in the present day, when the tendency of all our

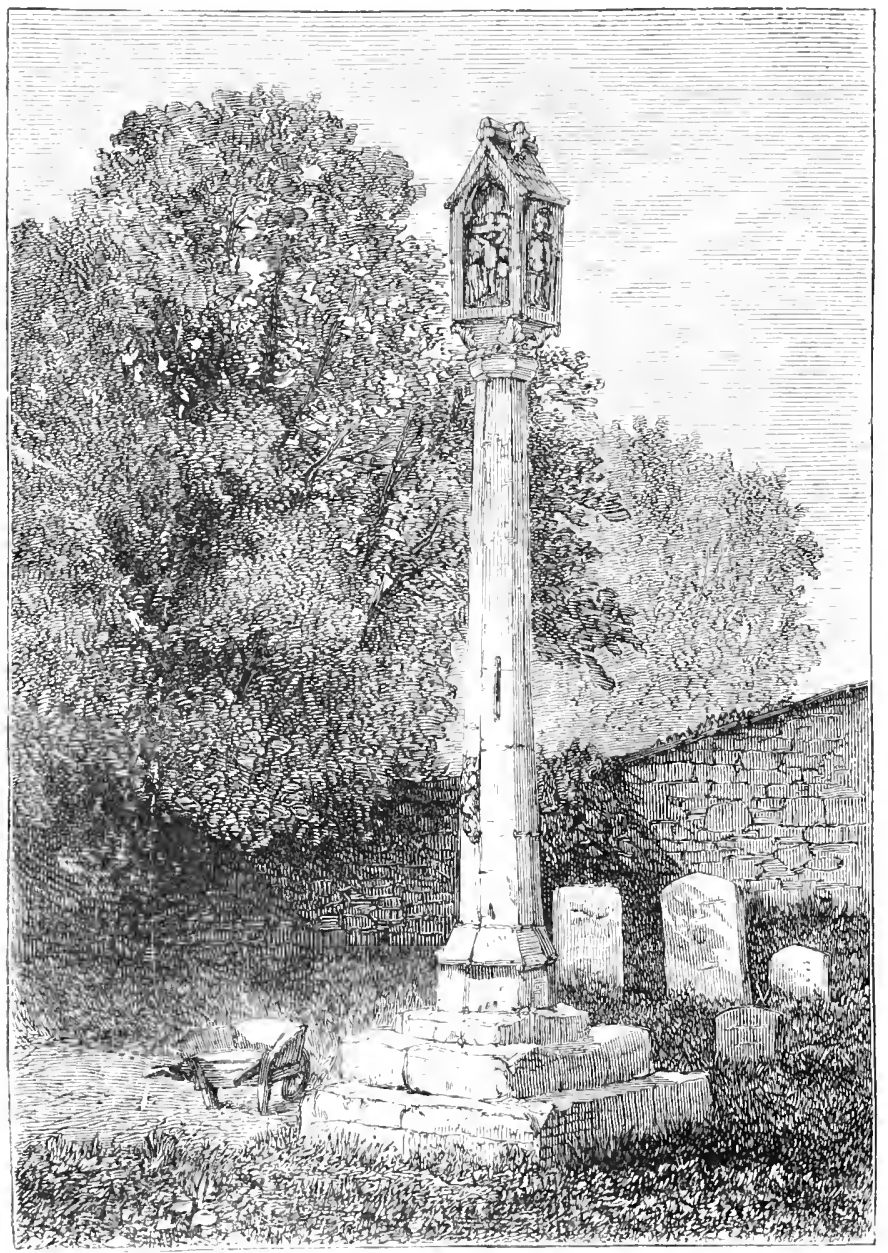

Cross at ampley Crucis.

teaching is rather to aroid making any exhibition of strong feeling. Undoubtedly there were many crosses 
connected with some demonstration; of course there were penitential crosses, where delinquents had to make a pitgrimage in a sheet in expiation of some offence. Penitential crosses were in use even in the Church of England until within the last thirty years, and that not always in obscure country villages.

The cross at Wedmore, in Somerset, is indeed, in another sense, an example of a weeping-cross. The terrible bloody assizes, as they were called, raged in these parts, and even the recollection of them would seem to be fresh in the minds of the inhabitants. It is two hundred years since they happened, yet people about there speak of them as a thing of yesterday. Jeffreys set out on what his infamous master called his "western campaign," and alluded to with such delight afterwards by that name. "Somerset, the chief seat of the rebellion, had been reserved for the last and most fearful vengeance. In this county two hundred and thirty-three prisoners were in a few days hanged, drawn, and quartered. At every spot where two roads met, on every market-place, on the green of every large village which had furnished Monmouth with soldiers, ironed corpses clattered in the wind, or heads and quarters, stuck on poles, poisoned the air; and the peasantry could not assemble in the house of God without seeing the ghastly face of a neighbour grinning at them over the porch. The chief justice was all himself; his spirits rose higher and higher as the work went on." Such is the account that Macaulay gives of a circuit that will be remembered while record lasts, and that has no parallel in English history. Wedmore lies at equal distances from Wells, Cheddar, and Glastonbury, and had 
furnished many soldiers to the cause of Monmouth, and to their memory this cross was erected; it was taken down from a neighbouring site and rebuilt in the pleasant old churchyard, and it still bears the name of "Jeffreys' Cross." It belongs apparently to the latter part of the fourteenth century, and is peculiarly elegant in its clesign, though unfortunately much rilapidated. At the top of the

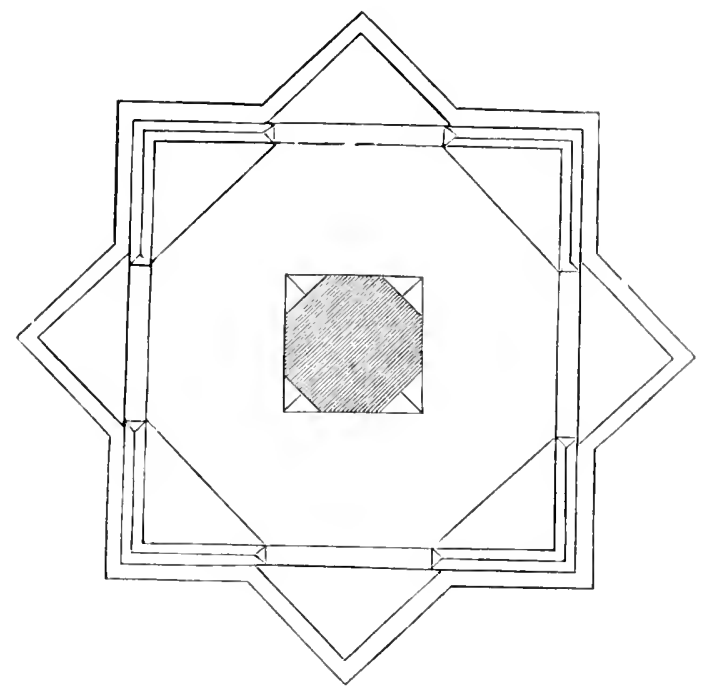

Ilan of Dundry' Cross.

octagonal shaft are flowers peculiar to the Decorated style; the set-offs above these are curved, thus giving a light and very graceful starting-point for the tabernacle part to rise from. All the parts of this tabernacle belong to the Decorated style. The cross, when perfect, must have been very beautiful. Though the ornamentation of the Decorated style is often very rich, it is never florid; it differs from the preceding style in not being so stiff or 
unnatural-looking, admirably adapted as the latter is for architectural effect; while it is equally different from that of the Perpendicular style which followed, being more natural, and dirived more generally from flowers and vegetation.

At Chew Magna there is a tolerable cross. It lies south of Bristol, on the Wells road, and is about six miles distant. The road to it is up Dundry Hill, and at the summit of this is an octagonal cross, rising from a flight of four steps and a solid base. The date of this cross is about 1500. There are panellings of a Perpendicular character on the solid base, consisting of a four-centred flat arch divided in two by a mullion. There are crosses also at Westbury and Compton Bishop, in the same direction, only a little farther to the south; and as for the stumps and shafts their name is legion, so numerous are they.

The crosses mentioned in this chapter are various in form, but all good examples; there are many more in the neighbourhood, but to illustrate them would make a tedious, bulky volume of very little interest; indeed, in investigations of this kind, one is continually doomed to disappointment; guide-books and inhabitants are communicative enough, and ready to give every kind of information in their power, but when the goal is reached -often in journeys connected with the present work in mid-winter and in boisterous weather-the result is an old flight of steps with a single shaft, and neither ornament nor inscription. 
XI.

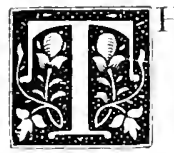

HERE are many crosses in England which must be passed over with but slight notice. The cross at Stevington, in Bedfordshire, is not unlike the crosses at Cricklade; the stops and splays are merely repetitions of old ones. Wheston cross is very elegant, but simple in form. It has two square steps, and a solid base over them; the latter is broached into an octagon. From this rises a light and elegant cross, with a Virgin and Child at the intersection of the arms; these arms are beautifully cusped on the outside. This cross was excellently drawn by Chantrey in 1818 , and engraved by Croke.

The cross at Scraptoft is curious, but much defaced; it seems to be of more ancient date, and probably belongs to the Early English period.

There was a fine old open cross in Leicester, built in the reign of Queen Mary: it was octagonal, and had a dado inside corresponding with the outer lines; an ogee roof covered it, but there was no central column. Leicester cross was pulled down in the year 1769 , but an excellent engraving of it was preserved at the time. Wymondham cross seems to have been a very picturesque oak structure, with a light central column. An engraving of it is pre- 
served in Bell's "Antiquities of Norfolk; " the oak beams were carved like an ornamental barge-board to a house; over it was an octagonal room, with a light high-sloping roof.

In some very old prints of market-crosses, we find them

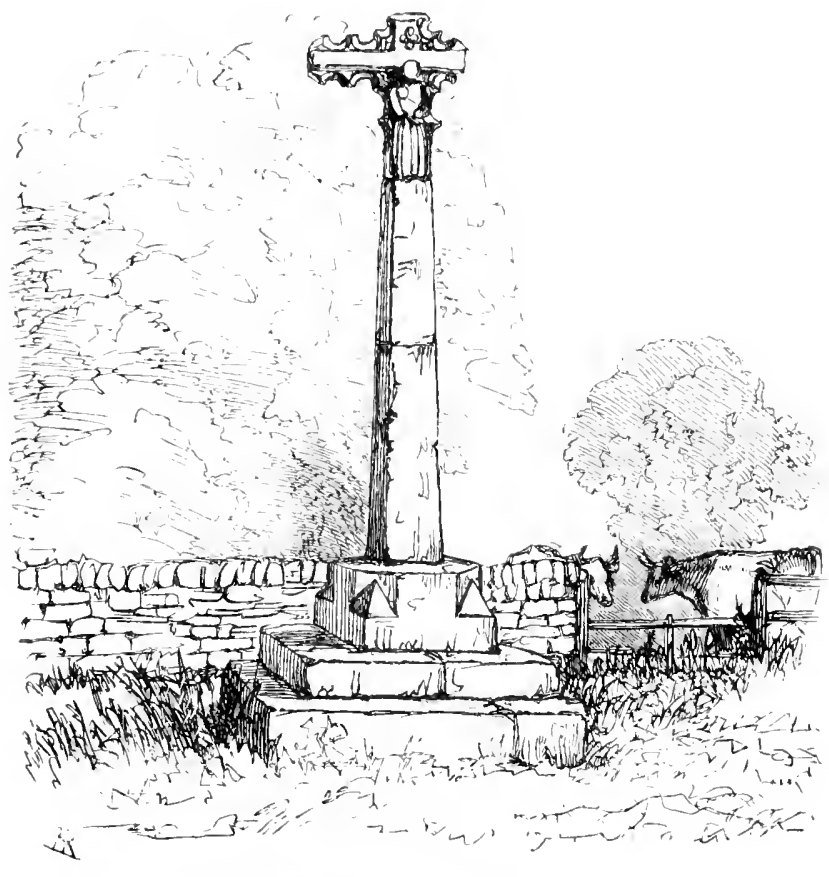

Whestun Cross, Derby.

surrounded by an enclosure about fifty feet square, built in the form of a wall to every appearance about five feet high, with a gateway, apparently to collect tolls; but how far this was general we perhaps hardly have sufficient examples left us to determine.

At Sutton St. James parish, IIolland, in Lincolnshire, 
are the remains of the celebrated Iry Cross; and at Willoughby-in-the-Wold is a good monolith fifteen feet high. At Penrith, in Cumberland, are some well-known monumental crosses, which again have hardly enough character to make them interesting subjects to delineate; and, indeed, it is only the great beauty of their situation that makes them known.

I have in my possession a good old print of a cross of which I am unable to find any record: it is a copper-plate apparently one hundred and twenty years old, and represents a structure which may be briefly described as follows: on a square base, "stopped" so as to form an octagonal top, rises a square monolith, at the top of which is a head curved outwards, and on this is a tabernacle with a Crucifixion, and some other groups on the three other sides, of which I have not succeeded so far in finding any explanation. A curious feature is that it resembles the form of the ancient cross in use at the beginning of our era, and is in the form of a $T$. The angles are beaded, and the beads are stopped five times over with heads and flowers. The work is old, and, so far as can be judged from the plate, is of the fourteenth century.

On the same sheet of paper is another cross, which is very curious, and perhaps unique. It stands on a round cheese-like base, which is supported on boulders; the angles are beaded, but not stopped; and there is a curious little cross cut out in relief on the front, which closely resembles a dagger. To neither of these crosses have I been able to find any clue.

In the cross at Dindar churchyard, in Somersetshire, which is here engraverl, the angles of the square monolith 
are beaded as in the one just mentioned, but these beads are worked in the form of small sunken angle-buttresses; there is nothing very peculiar about this cross, and it is represented chiefly to illustrate what is meant by beadedangles. Dindar Church, which is also partially indicated,

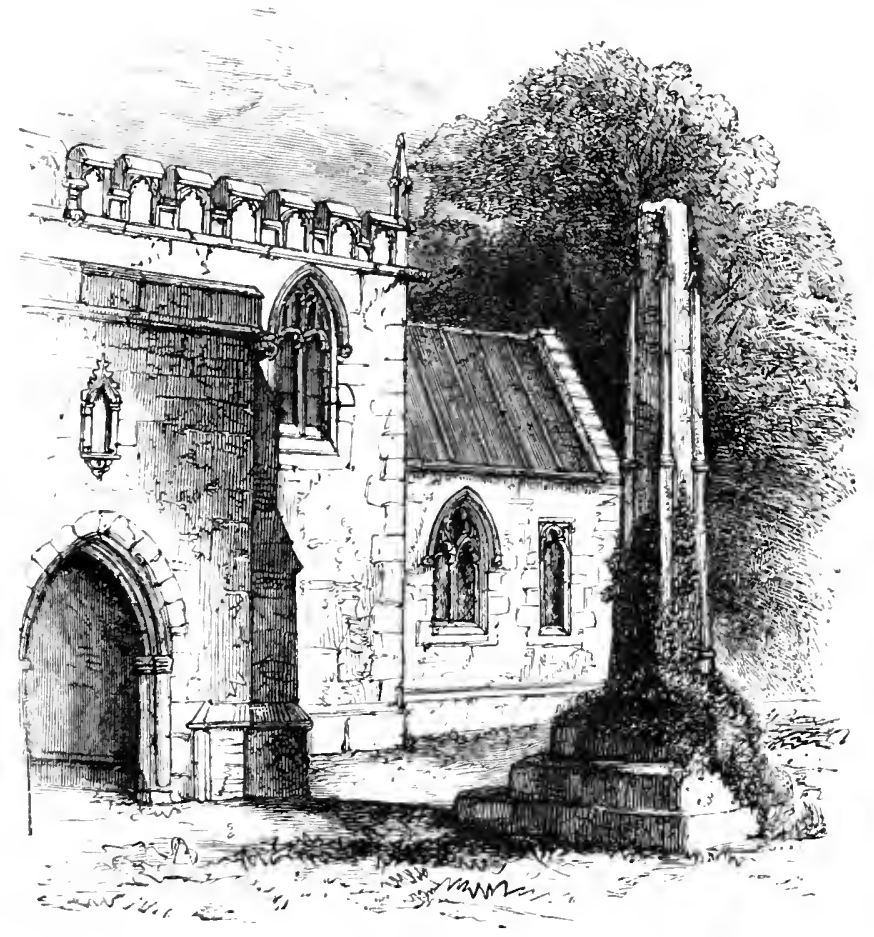

Dindar Cross.

is rather an interesting old building, and has a good Early Perpendicular porch and battlement.

Devizes is an ancient town in Wiltshire, of great historical interest, which had a noble castle built by Roger, Bishop of Salisbury, at an immense expense. He raised 
himself from being a poor parish-priest to the second rank in the kingdom; but stephen, bearing him a grudge

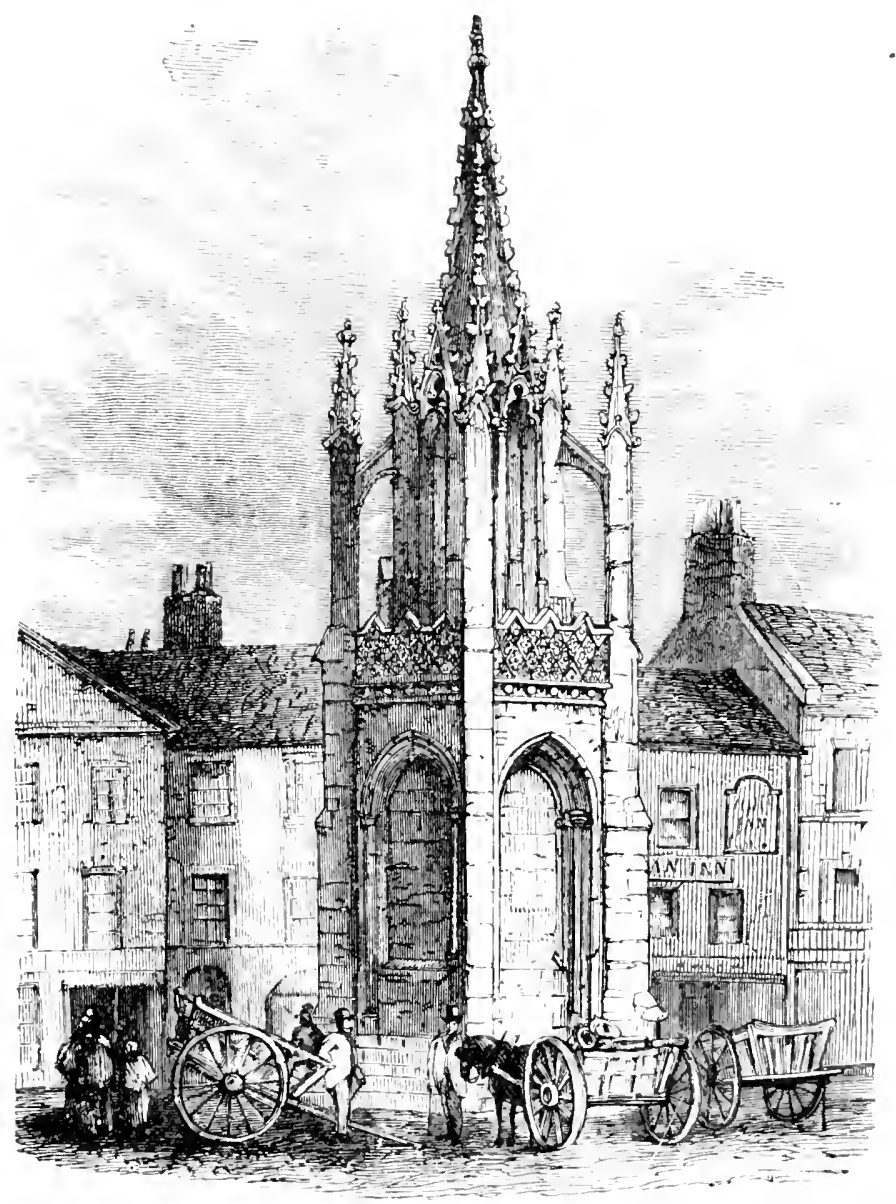

Mrizes Cross, llittshire.

similar to that of Henry VIII. against Cardinal Wolsey, deprived him of his great wealth, made him give up this castle, which was second to none in the kingtom, and 
reduced him again to abject poverty. The singular name of this town is said to be derived from the division of it between the Bishop of Salisbury and the king, in very early times.

The market-cross stands in the market-square, and consists of a solid base with a band of quatrefoils over, and flying buttresses at the angles. It is not perhaps very elegant in contour, but it is curious and characteristic. There is a singular inscription on it, which runs thus :-

"The Mayor and Corporation of Devizes avail themselves of the stability of this building to transmit to future times the record of an awful event which occurred in this market-place in the year 1753, hoping that such a record may serve as a salutary warning against the danger of impiously invoking, the Divine vengeance, or of calling on the holy name of God to conceal the devices of falsehood and fraud.

"On Thursday, the 25th January, 1753, Ruth Pierce, of Petterne, in this county, agreed with three other women to buy a sack of wheat in the market, each paying her due proportion towards the same.

"One of these women, in collecting the several quarters of money, discovered a deficiency, and demanded of Ruth Pierce the sum which was wanting to make good the amount.

" Ruth Pierce protested that she had paid her share, and said she wished she might drop clead if she had not.

"She rashly repeated this awful wish, when, to the consternation of the surrounding multitude, she instantly fell down and expired, having the money concealed in her hand." 
This cross, though very different in form, is probably contemporaneous with that at Shepton-Mallet.

The legend above given is intelligible, for many such sudden deaths under similar circumstances, where there has been great excitement, have been credibly recorded. Of course there is nothing irreverent in supposing that an inquest might have discovered some old vital complaint, such as heart-disease, to be present at the time.

A celebrated cross stood in the monastery of Winchester, which was built by King Alfred for married monks. This cross spoke out openly and fervently against monks marrying: and in consequence, Dunstan, Bishop of Canterbury, turned them out, and they were superseded by others of celibate vows. There is a tradition that Canute had spent the revenues of one year of his kingdom over this cross, and worthily it seems to have requited his labours.

Eltham Cross, in the county of Kent, is broken down, though the old palace in part remains, and is one of the glories of English architecture. It was deserted at the time of the building of Greenwich, except perhaps occasionally by James I.; and during the Commonwealth, it served as a stone quarry for the erection of neighbouring buildings: incleed, it was only the accident of the hall being used as a barn that preserved it from destruction. The grand roof has been restored by Mr. Smirke, at the expense of the Government. There was a great destruction of crosses in this part of England-indeed, they have almost all been swept away.

Bitterley Cross stands in the churchyard of Bitterley, Shropshire, a village near the quaint and quiet old town of Lurllow, a town that possesses a castle which is celebrated 
all over England, and is contemporaneous with Warwick, Warkworth, Alnwick, and others that figure in English history. The steep streets and black and white gabled houses, also, of Ludlow, give one-next perhaps to Chester

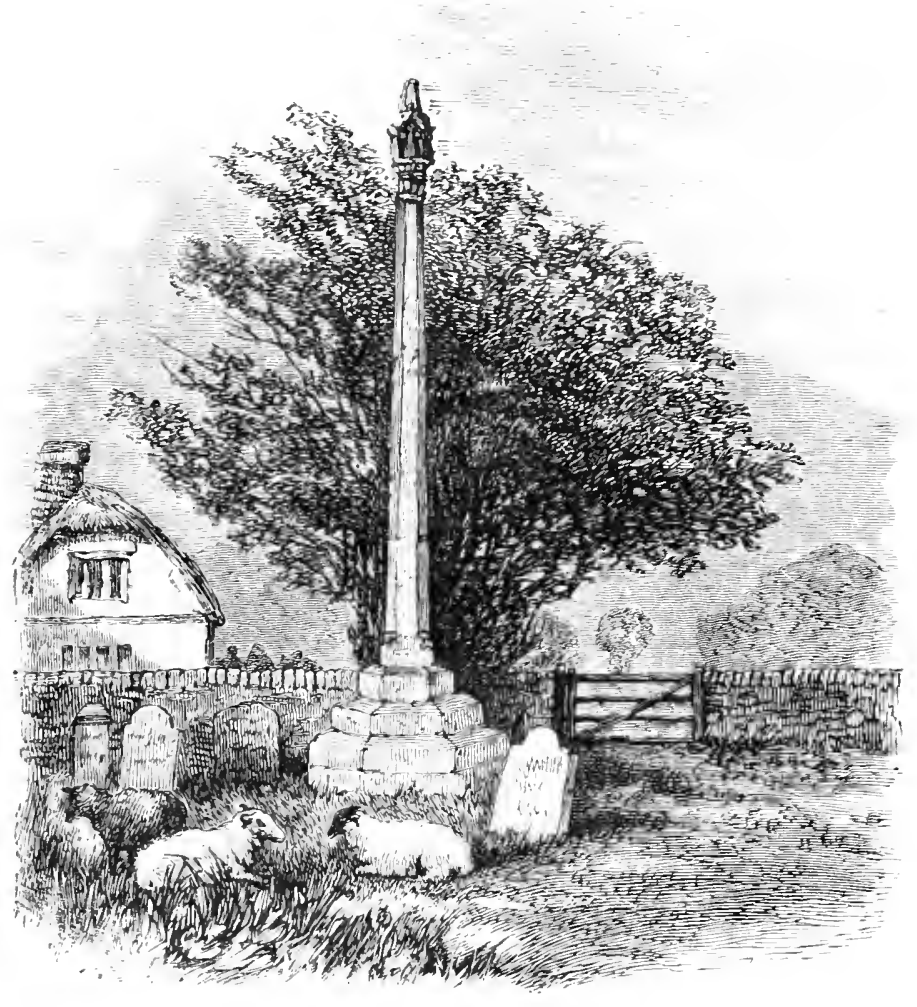

bitterley' (ross, wirlop.

-the best idea we can have of a mediæeval English country-town. The road to Bitterley is remarkably beautiful; there are hills on each side cultivated to the summit, while the village is literally shut in with great elms and 
walnut-trees, through which gables and high twisted chimneys appear at intervals. The church is situated in the park of Bitterley Court, and the lord of the manor is the rector. There are several peculiarities about the architecture of the church, which is small, and was principally erected apparently in the reign of Richard II. The cross was also built about this time, and is very graceful in its outline; probably it was originally intencled for what is called a weeping-cross. There are four steps to it ; the "stops" that convert the square base of the shaft into an octagon are peculiarly beautiful and ingenious.

Behind the cross is a great yew-tree, and the abrupt ridge of the hill rises up in the background. Perhaps it would be difficult to find a better example of a tall tabernacle cross in England. Under the representation of the Crucifixion are some light and peculiar brackets that are almost unique, and rather resemble thirteenth-century work.

There are crosses at Broughton and at Kinnerley, in the northern part of this county, and also at Great Ness, Middle Ness, and Little Ness, in the southern part; but these do not differ materially, they are built on the old type we see throughout Gloucestershire-a flight of steps and an octagonal shaft, with the tabernacle part containing the images destroyed.

Not only have crosses of all kinds been better preserved in Gloucestershire, Wiltshire, and Somersetshire, but many have been restored to their former state, either by the owners of the soil, or by the clergy assisted by the efforts of their parishioners. There are two crosses at Cricklade of great beauty of proportion. One is repre- 
sented as standing in the road, where, until recently, it used to stand, though now it is removed into St. sampson's churchyard. This cross was apparently built at

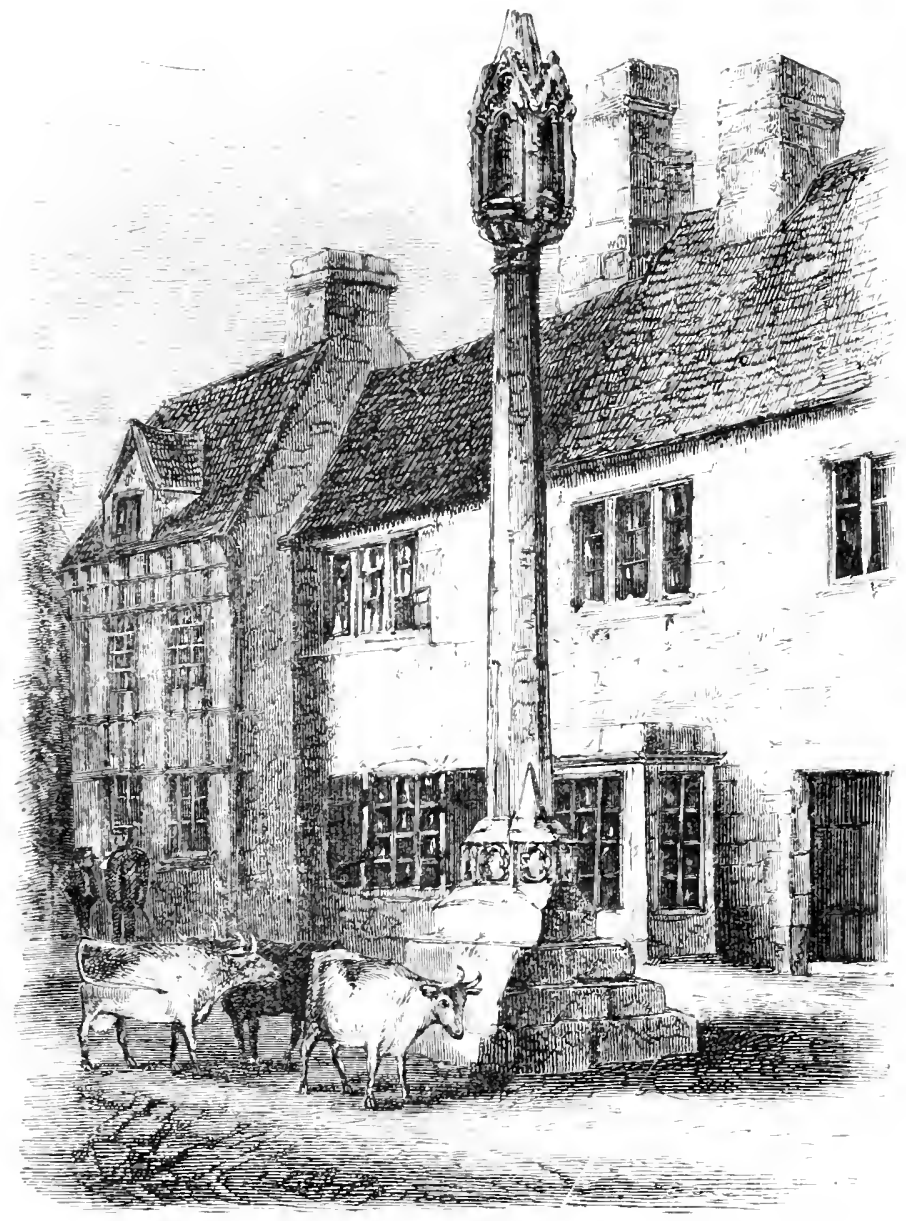

Cross at Cricklade (now in St. Sampson's Churchyard).

the close of the fourteenth century, and is certainly a pattern of lightness and beauty; of course it cannot com- 


\section{1+2 ANCIENT STONE CROSSES OF ENGLAND.}

pare for a moment with the Eleanor crosses, which were the result of profuse wealth and unlimited expenditure, but it is a perfect model of a village-cross. Waltham Cross, for example, could not now be built for less than

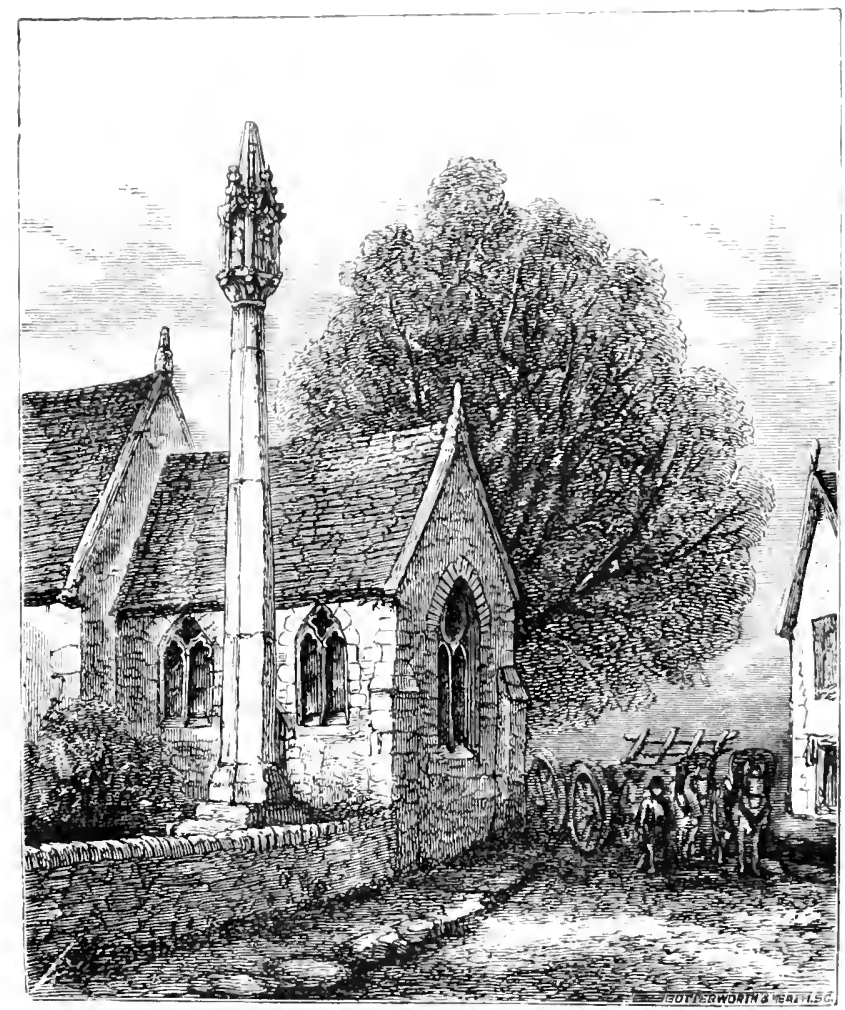

Cross at C'ricklade (in sit. Mary's (huritededi).

two thousand pounds, including the beautiful statuary; but such a cross as Cricklade might be erected for about a hundred or a hundred and twenty pounds, even at the present advanced price of labour. This cross formerly stood on four substantial stone-steps, the top one was berelled 
off very neatly into an octagonal base, and it was surmounted by eight very elegant quatrefoils; these, again, were splayed off till they assumed the proportions of the. shaft. The shaft is crowned with a very fine tabernacle, having four angels for supporters; but the figures in the niches of the tabernacle have unfortunately disappeared. This cross has been engraved in Britton's "Antiquities of England;" there is also an excellent little copper-plate by Roberts, from a drawing by John Hughes, for the "Antiquarian Itinerary," date i 8 i 7 , and published by Clarke, of New Bond Street. There are also several other engravings of it before me, but they are not dated, though apparently of equal, or perhaps rather greater, age.

This cross has, as before stated, been removed into St. Sampson's churchyard, where it has been carefully re-erected. At the further end of the town is another and very similar structure, which stands in St. Mary's churchyard, and forms a most beautiful outline against the chancel of the old parish church. The figures are complete in this, and the shaft is very similar, but the base is not so graceful as that of the other cross. On the sicle facing the road are two figures in one canopy, which seem to be those of a knight and lady, possibly the builclers of the cross.

There is a curious tradition regarding the origin of the name of Cricklade. Some persons, Camden tells us, are of opinion that it is a corruption of Grekelade, from the circumstance that "Greek philosophers" founded a university there, which was afterwards removed to Oxford. Undoubtedly, according to the monks, such a university did at one time exist; but to derive the name from this is 
rather a forced example of etymology; and the circumstance that the university was said to be removed to Oxford long before there was any university at all, clearly militates against the credibility of the narrative.

The cross at Pershore, in Worcestershire, resembles those at Cricklade in proportions, though it is eren simpler and plainer in design; it stands on two steps, and on the top one is a solid base "broached." The tabernacle of this cross has been destroyed. Pershore is said to derive its name from the number of pear-trees that grew in its vicinity; it is delightfully situated on the Aron. The cross is a preaching-cross, and was connected with the monastery, of which some picturesque remains are yet standing. There were other crosses here, but they have been destroyed. Near the Gateway, which at present remains, stood the small chapel of Sit. Edburga, to whom the abbey was dedicated: she was a daughter of Edward the elder. Her father once placed before her some valuable jewels and clothes of the latest fashion, and also, a little way apart, a copy of the New Testament, desiring her to choose between them, when she at once rejected the garments and jewels for the New Testament; after which her father sent her to Winchester, where she died, and where her bones were preserved as a valuable relic for many ages. There were two crosses at Pershore to her memory. 
XII.

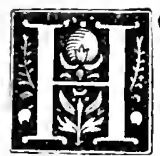

OLBEACII Cross was pulled down at the latter end of the seventeenth century, but a very fair print of it still exists, taken from a drawing by Dr. Stukeley in 1722. A legend on the engraving reads-" Ob amorem erga solum natale temporum ignorantia direptam restituit. Wo. Stukeley." The cross is so curious, and the print itself is so scarce, that it was thought well to copy it for the present work, only altering the lines of perspective, and correcting some very obvious errors that show for themselves in the details. The cross was pentagonal, after the manner of Leighton-Buzzard, but it had no central column, the angle buttresses acting instead; this gives the structure great lightness, and increases its capacity as a shelter. There were five angle-pinnacles to support the lateral thrusts, and the edifice was groined inside.

The woodcut here introduced probably gives a very fair idea of this beautiful and interesting structure, which is unique, and deeply we must share Dr. Stukeley's regret at its destruction.

Holbeach is an old-fashioned town in Lincolnshire, and is about forty miles south-east of Lincoln; it was formerly 
It A ACIENT STOME CROSSES OF EMGLAMD.

called Ollbeche, from the town having been built near an

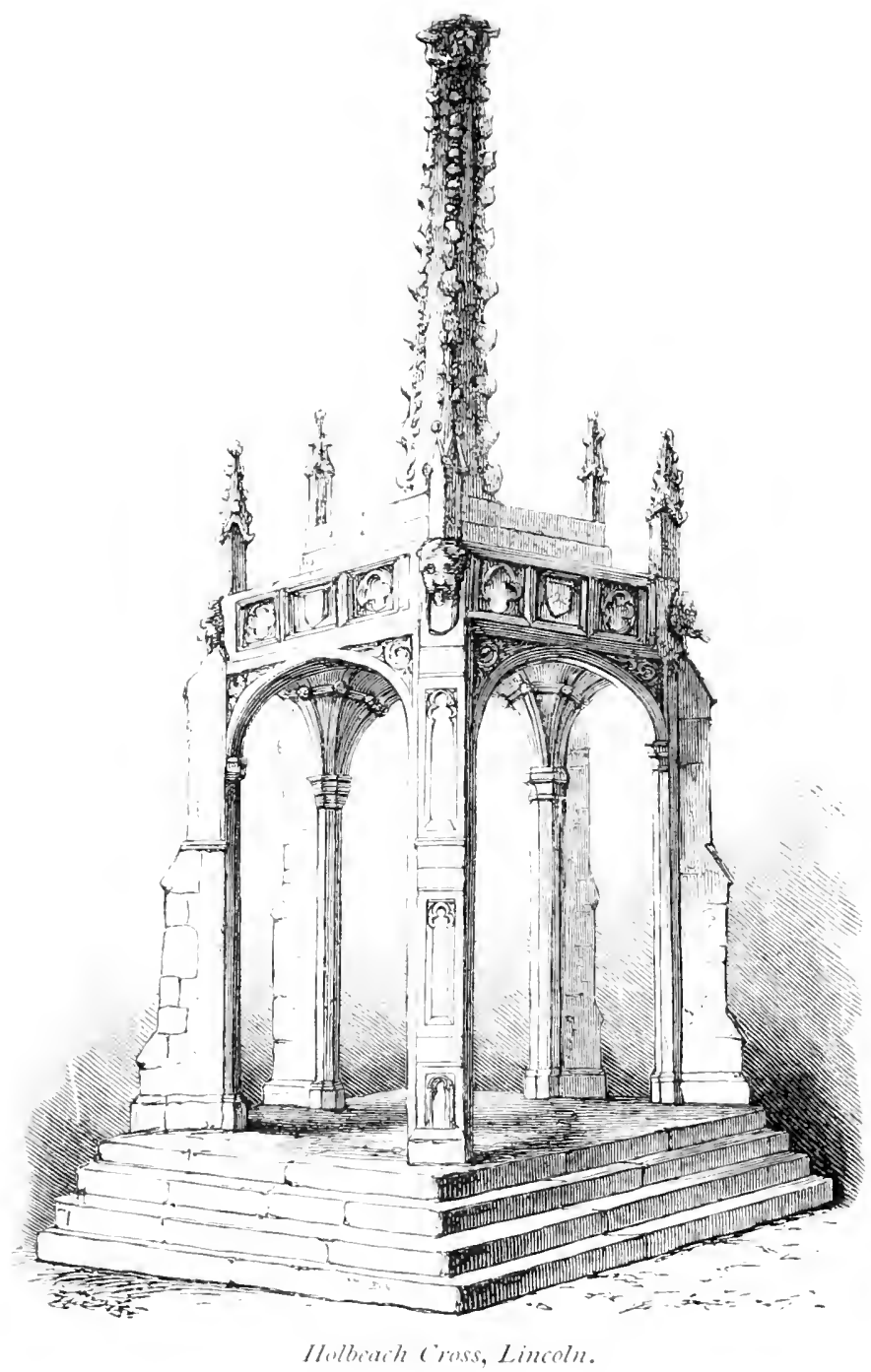

old beach left by the recession of the sea. It contains a fine old church, and there is a free grammar school, 
founcled by Ldward III.; the lands, however, which were granted for its support seem to be unaccountably lost. Holbeach was the birthplace of the learned Dr. Stukeley, the antiquary, author of Itincrarium Curiosum.

There are no remains of the crosses that formerly adorned Lincoln city; indeed, this part of England is not by any means so rich in crosses as in other ecclesiastical remains. Boston and Grantham crosses seem to be more remarkable for the height of their steps, rather than for any architectural features of merit. The latter is a high octagonal shaft on a flight of steps that diminish rather gracefully; and the shaft also diminishes until it reaches its proper thickness.

At Lincoln, however, is a fine old waysicle conduit, which is fairly entitled to rank among the crosses of England. It is situated near St. Mary's de Wigford Church, said to be one of the few Saxon remains in England. The cross is rectangular in plan, and has angle-buttresses; the panelling is of the fourteenth century-towards the latter part of that period-and is very graceful. It is the finest example of a well-cross left in England. The water which supplies the little basin is brought through leaden pipes from a distance of a mile; these pipes are more modern than the structure, having been laid down during the reign of Queen Elizabeth.

There is no doubt that, from whatever cause, the crosses in this part of England, and as far west as Shropshire, were those that suffered most. Two ludicrously helplesslooking statuettes of Crispin and Crispianus over a shoemakers' resort in Shrewsbury, as if cleprecating the 
Puritan zeal that was lestroying so many of their fellows, $\therefore a y^{*}-$

"We are hut images of strune,

low ue ho ham-we can do nomne."

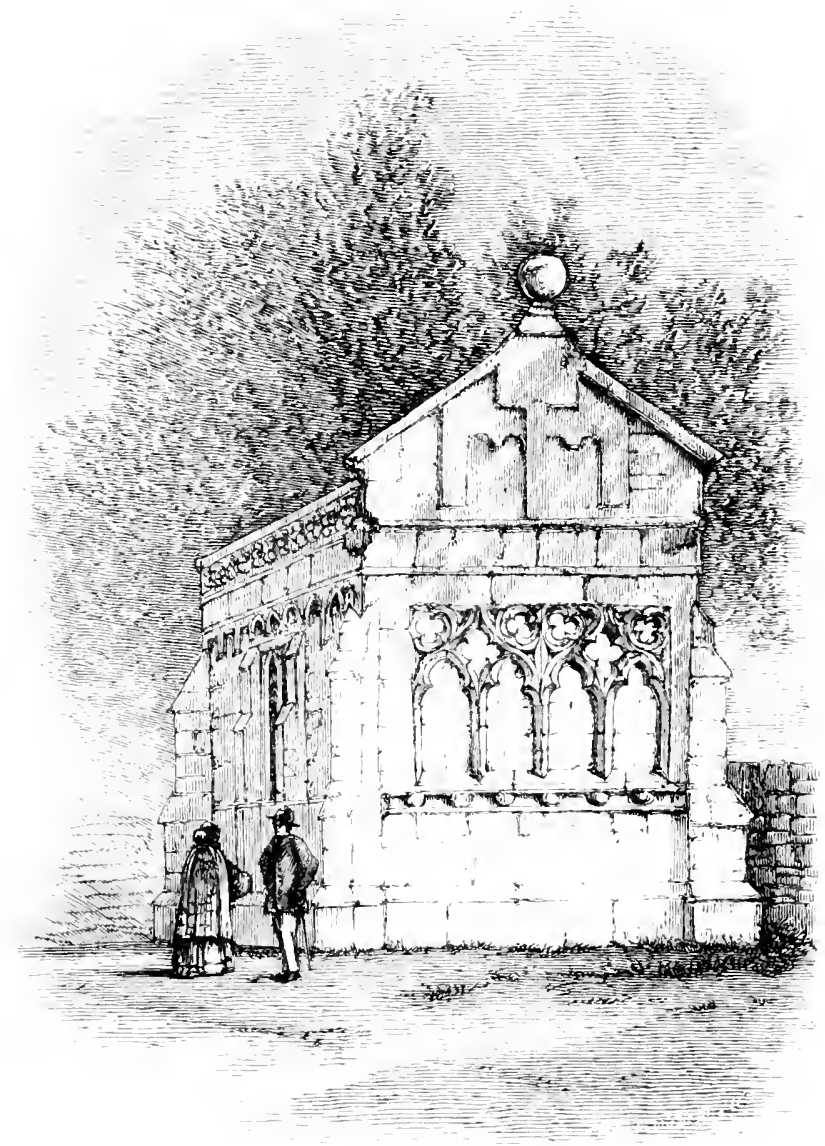

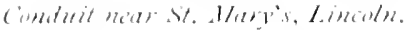

St. Mary's Cross is situated in IIgh Street, Lincoln, which is one of the finest old English streets left; the vast 
cathedral, from its height, seems to overshadow the city as we walk up towards it, and many are the remains of antiquity on each side. The actual high-cross of Lincoln, as it is properly called, was destroyed long ago. Remigius built a cross here, which has perished; he founded the see of Lincoln, having removed it from Dorsctshire. Hugh de Grenoble also built one or two crosses in Lincoln which have likewise perished; he succeeded Remigius, and after him Hugh de Wells and Bishop Wells built crosses which have shared no better fate than their preclecessors.

Langley is about ten miles from Norwich; at one time it contained a monastery. The singular old cross is probably of the fifteenth century, though it may be a little earlier. On the panel at the north side there seems to be the figure of an angel unfolding a scroll, though it is not very certain what this is. On the east and west are two grotesque animals; that on the west has wings, and that on the east side seems to be a sort of parody upon a lion. The canopied statues are curious, and unlike any others we can call to mind; three of them are holding shields, and the fourth, on the east side, has a singular model of a lamb. The splayed base is very curious, and there are no traces of its having been broached.

Langley Cross is situated in the hundred of Lodden, which is about nine miles and a half distant from Norwich, in a south-easterly direction. The river Yare, on which Norwich is situated, is close by, and the country is very beautiful. Langley Park has long been the seat of the Proctor family; the grounds cover eight 
150 ANCIEMT STOVE CROSSES OF ENGLATD.

hunclred acres. Langley Abbey, to the good offices of which we owe the cross, was founded for the Premonstratensian canons, in the year 1198, and was dedicated to

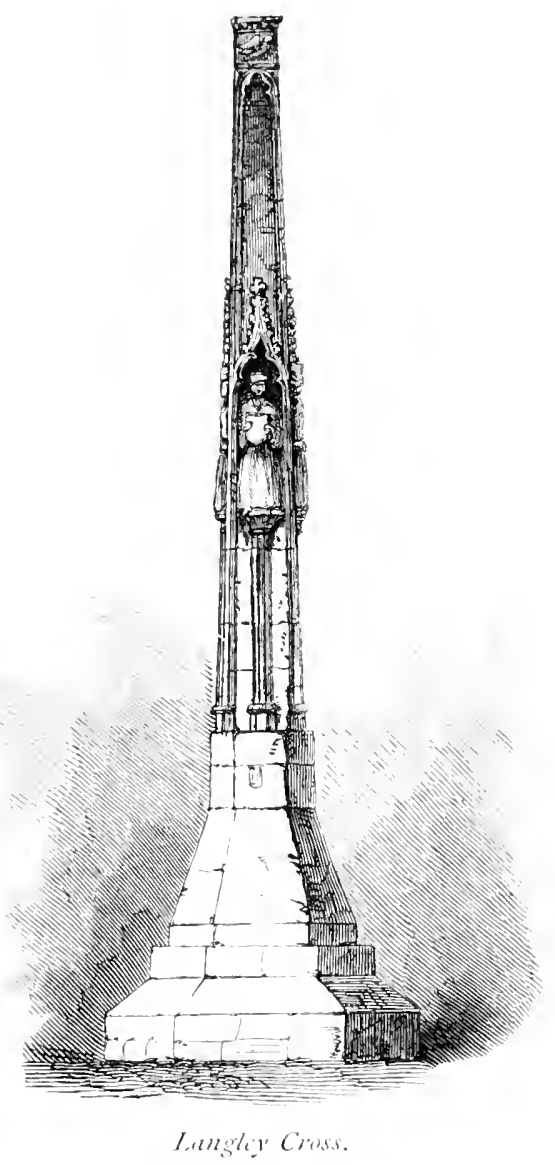

the Virgin Mary. There were at one time in all fifteen religious houses here, ant their united revenues, at the dissolution of monasteries in the reign of Jlenry VIII., wref:20. 
The Monastery of Norwich, some ten miles distant, is remarkable for having been the scene of many conflicts between the inhabitants of the city and the clergy. There

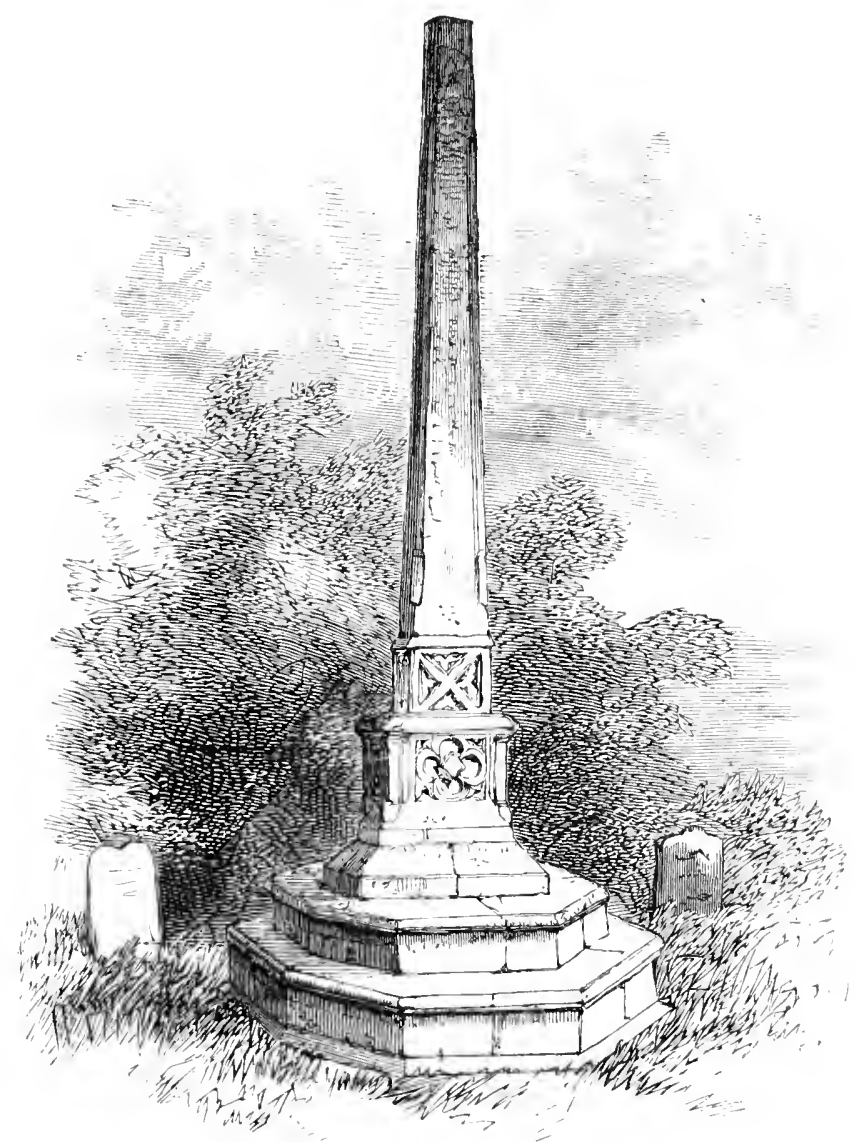

North Petherton Cross.

were several very beautiful crosses in its jurisdiction, erected at the expense of the monks; but they were ruclely destroyed by the soldiers of Cromwell, who filled the cathedral, as Bishop Hall pathetically says, "drink- 
ing and tobaccoing as freely as if it had turned alehouse."

North Petherton Cross is situated in a pleasant part of Somersetshire, and is a good example of Perpendicular work, though without the tabernacle. The square sides wive it rather the appearance of an obelisk.

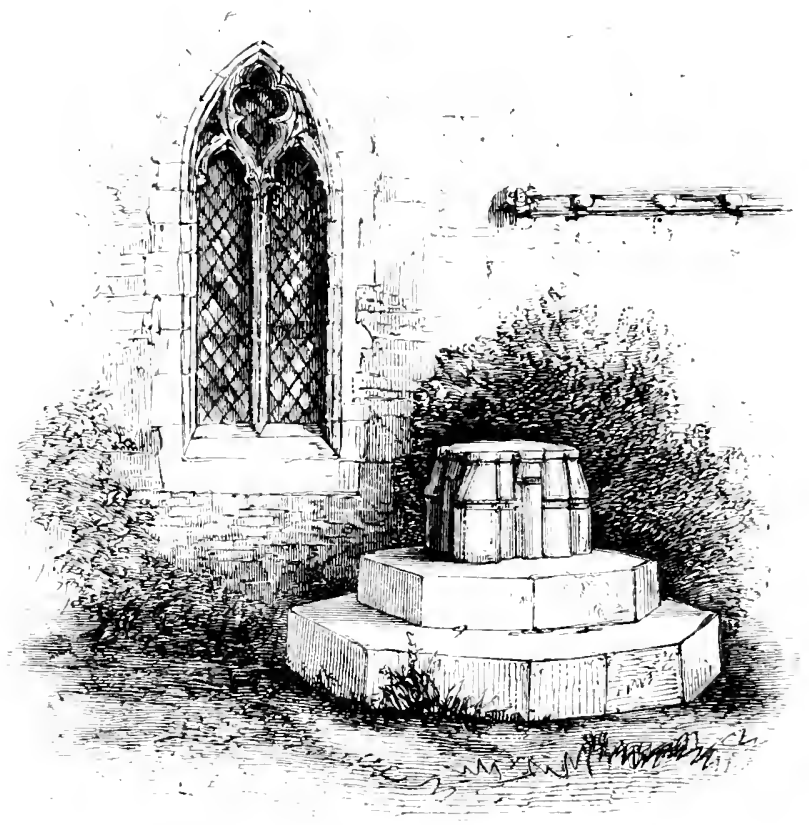

Base of a Cross in Bebbington Churhyord, Cheshire.

Bebbington Churchyard, near Chester, contains a fine old base (circ. 1500); and in the grounds of Delamere Abbey is the head of a cross apparently about A.D. 1350, - probably one of the sanctuary crosses before spoken of, where travellers halted on their road through the dangerous Royal forest. 
In concluding this brief history of the crosses of England it is of course obvious that a number of unimportant examples must have been omitted, and perhaps it may be thought that undue prominence has been given to others. The fact must be borne in mind, that the materials for writing such a history are slight, but wherever any records

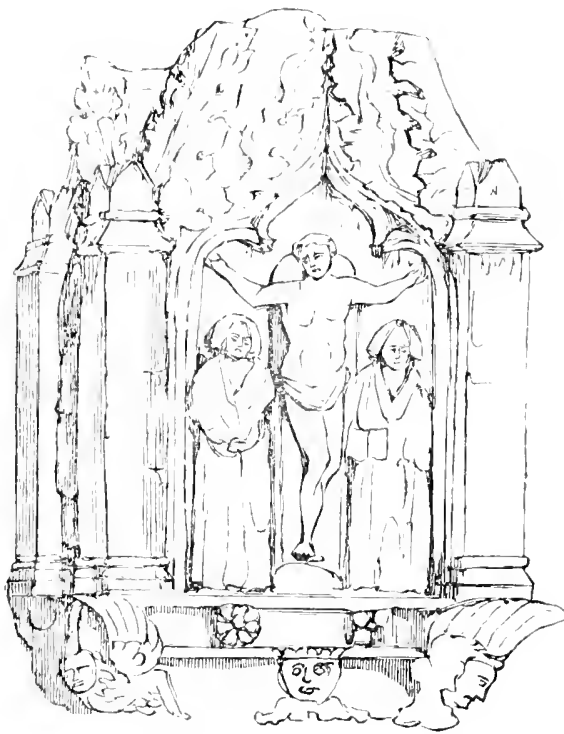

Head of Cross, Delamere, Cheshire.

have been obtainable they have been made use of; probably, also, the story of one cross would be that of a hundred others. Fosbrooke, in his curious book of antiquities, has given a methoclical list of the different forms. There are first, he says, the praching-crosscs, or crosses from which friars used to preach. Then there are the market-crosses, of which so much has been said, and which, in fact, constitute the principal remains now in England. 
IIe also enumerates arefing-crosses, or penitential shrines; and then strect-crosses, which perhaps are included in market and preaching crosses; crosses of memorial, built either as sepulchral monuments or in memory of some notable action; lamdmark-crosses, which differ materially from every other kind mentioned, and were, and are yet, the most accurate and reliable clata in parish boundaries. The abbey-lands round Chester seem to have been marked out with great regularity in this way, though incleed many, or nearly all of them, were destroyed very long ago. He also mentions crossis of small stoncs, where a person has been killed; crosses in the highat $(y)$-these were, of course, of every kind, either like the Eleanor crosses, or boundarycrosses, or, indeed, preaching-crosses; crosses at the cutrance of climclas, to inspire devotion-and, unhappily, these beautiful remains seem to have suffered more severely from Puritan zeal than any other. Finally, he enumerates crosses of attestation of peace, ereeted by some monarch who was defeated or otherwise; these are mostly of a very ancient type. This list of Fosbrooke's is very curious and interesting, it may be a little fanciful; but he was a keen observer, and had the advantage of seeing many crosses now no more. It also affords indireet evidence of the number of these structures which must at one time have adorned the land.

Doubtless our wayside monuments or crosses sink into insignificance when compared with those of the old Appian Way leading into Rome; perhaps, indeed, nothing can give us even the slightest iclea of this extraordinary scene, for the history of the world contains no parallel. The monuments erected along the wayside clwarf our 
Eleanor crosses as far as cost was concerned. The Appian Way was, in fact, one vast Westminster Abbey, a quarter of a mile deep in monuments, and sixteen miles in length, broken here and there by some luxurious, magnificent villa, such as that of the Quintilii, whose grand retreat proved too great a temptation to Commodus, and caused him to have them destroyed, in order that this infamous usurper might inhabit their halls. The present Pope has earned the gratitucle of all students of antiquity by the excellent means he has taken to have all monuments restored, and the débris removed as far as possible; though even with this advantage we shall never again have more than a very slight idea of the Appian Way in its grandeur, for invaders of the Eternal City, such as Alaric, Totila, and Belisarius, laid her suburbs waste, breaking down the carved work of these wayside monuments, and using up the materials for any possible purpose they might require them; indeed, considering the extent of the remains after such visitations, the wonder is that any wayside monument is left at all. But not only was the Appian Way adorned with roadside monuments, the Flaminian and Latin ways were also lined with grand tombs; Juvenal says :-

"Quorum Flaminiâ tegitur cinis atque Latinâ."

There are many Christian tombs along these roads erected at a later period, and bearing the symbols of the Christian creed, which, indeed, might pass for classic monumental roadside crosses.

Greek artists were employed on these beautiful memo- 
rials, or, at any rate, on the best of them, and we should have to go back to the days of Alaric to know what they were like. The destruction of our own roadsicle crosses has been almost as complete, and perhaps as many priceless designs have also been lost among them.

On the way in which roadsicle monuments, as well as other ancient buildings, were made to suit the character of the surrounding scenery, there is an interesting example in that delightful book, Laborde's "Sinai," and I venture to quote some remarks I once made on a former occasion on this subject :-

"Perhaps Idumea is among the least promising sites for an architect to attempt to mould into beauty, but it illustrates the point under consideration well. This was the ancient city of Edom, and was situated in the very middle of the rocky fastnesses of Arabia Petraea. It was approached by only one long road of about four miles, which has no parallel in history. The hills rise up abruptly on each side to some four hundred feet in height; and they often appear to close over the head, owing to projections in the rocks at vast heights above. In places it is of course quite lark, and only a gleam of light ahead directs the traveller. Yet this astonishing highway was once corered with geometrical pavement, and its sides were lined, wherever an opening renclered it possible, with monuments and memorials corresponding with English roadside crosses in aims and uses. Ages before the Roman occupation, Edom was looked upon with mysterious awe: "Who will lead me into the strong city? who will bring me into Edom ?",

The amazing scene that presented itself at the end of 
this street is familiar to us from reading the pages of Laborde. Rocks eut and searped out into temples, tombs, and dwellings are scattered about in great profusion; but all harmonize with the landseape, if so it can be ealled, for the tunnel-like road ends in a kind of vast amphitheatre, formerly the great eity. Just before it terminates is a rock temple, beautifully illustrated in Laborde's book, and which appears to be of the time of Vespasian or Titus, and shows how well old architects could improve even a gleam of light, so long as it was a recognisedly permanent feature, and not to be clisturbed by passing erents; but it cannot be given better than in the words of Captains Irby and Mangles, who are among the very few Europeans that ever saw these regions:-

"When the rocks are at the highest, a beam of stronger light breaks in at the close of the clark perspective, and opens to view-half seen at first through the narrow opening-columns, statues, and cornices, of a light and finished taste, as if fresh from the chisel, without the tints or the weather-stains of age, and executed in a stone of pale rose colour, which was warmed, at the moment we came in sight of them, with the rays of the morning sun. The dark green of the shrubs that grow in this perpetual shade, and the sombre appearance of the passage whence we were about to issue, formed a fine contrast with the glowing colours of the edifice. We know not with what to compare this seene; perhaps there is nothing in the world that resembles it. Only a portion of a very extensive architectural elevation is seen at first; but it has been so contrived that a statue with expanded wings, perhaps of Victory, just fills the centre of the aperture 
in front, which, being closed below by the sides of the rocks folding over each other, gives to the figure the appearance of being suspended in the air at a great height, the ruggedness of the cliffs below setting off the sculpture to the highest adrantage. The rest of the vast façade opened gradually at every step as we advanced."

With this sublime description of a wayside monument, erroneously called by the Arabs Pharaoh's tomb, we may bring our notices of the stone crosses of England to a close. Of course we have no such grand opportunities to misuse in England; but one thing is certain, that until recently architects rarely considered their surroundings, but simply drew their plans on paper, in four square walls, clisdaining everything in the shape of picturesque adaptability.

In regarding the old crosses (which are, perhaps, not at all times the most beautiful architecture of their age, always excepting the Eleanor crosses, and remembering that we know very little of the others), we naturally fall into this train of reflection; those we have noticed seem, as a general rule, to be clesigned to fit their situation, and form a pleasant object in the landscape. On this subject, as we have before remarked, an architect who has a building to erect should carefully sketch the site and the landscape, in order to see how the building will look from the various windings of the highway; where it should stand clear of a hillock or a group of elms; where chimneys would tell, or where bow wincows; and finally look upon it as a picture set in a frame. And he is sadly wanting in ingenuity who is not able with 
ease to adapt this to the requirements of his work; indeed, such a general survey would be of the greatest possible assistance in the item of the arrangement of the rooms of a building; say, for example, a dwellinghouse. It would at once relieve him of much consideration as to where rooms of entertainment should be, where the domestic offices or stables should stand, and how far the buikting should be from the road, with many other problems that he is only working at in the dark in his office.

IIIE ENII. 
$=$ 

UNIVERSITY OF CALIFORNIA LIBRARY

$$
\text { Los Angeles }
$$

This book is DUE on the last date stamped below.

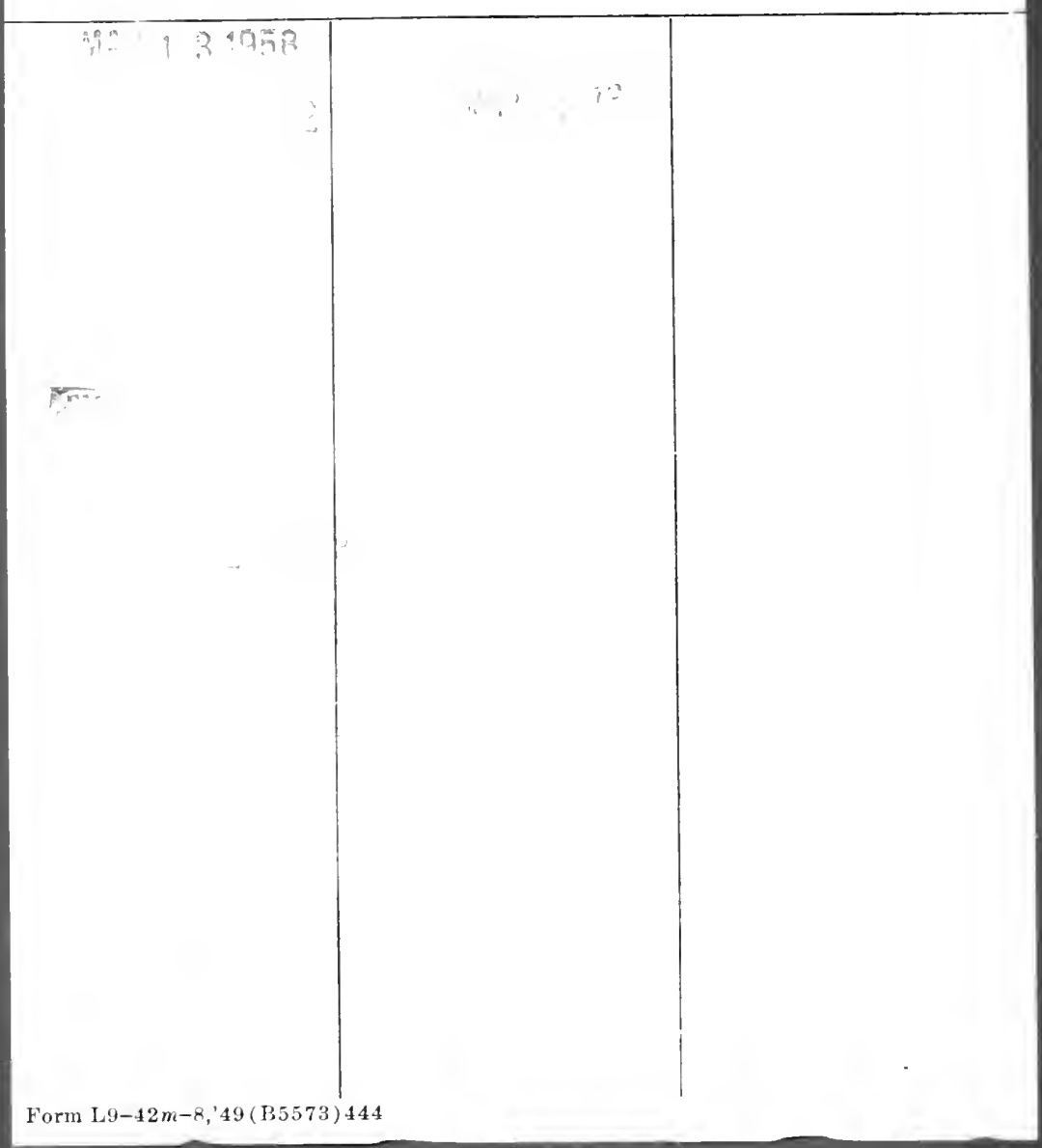


UC SOUTHERN REGIONAL LIBRARY FACILITY

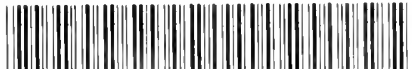
AA $001095182 \quad 0$ 


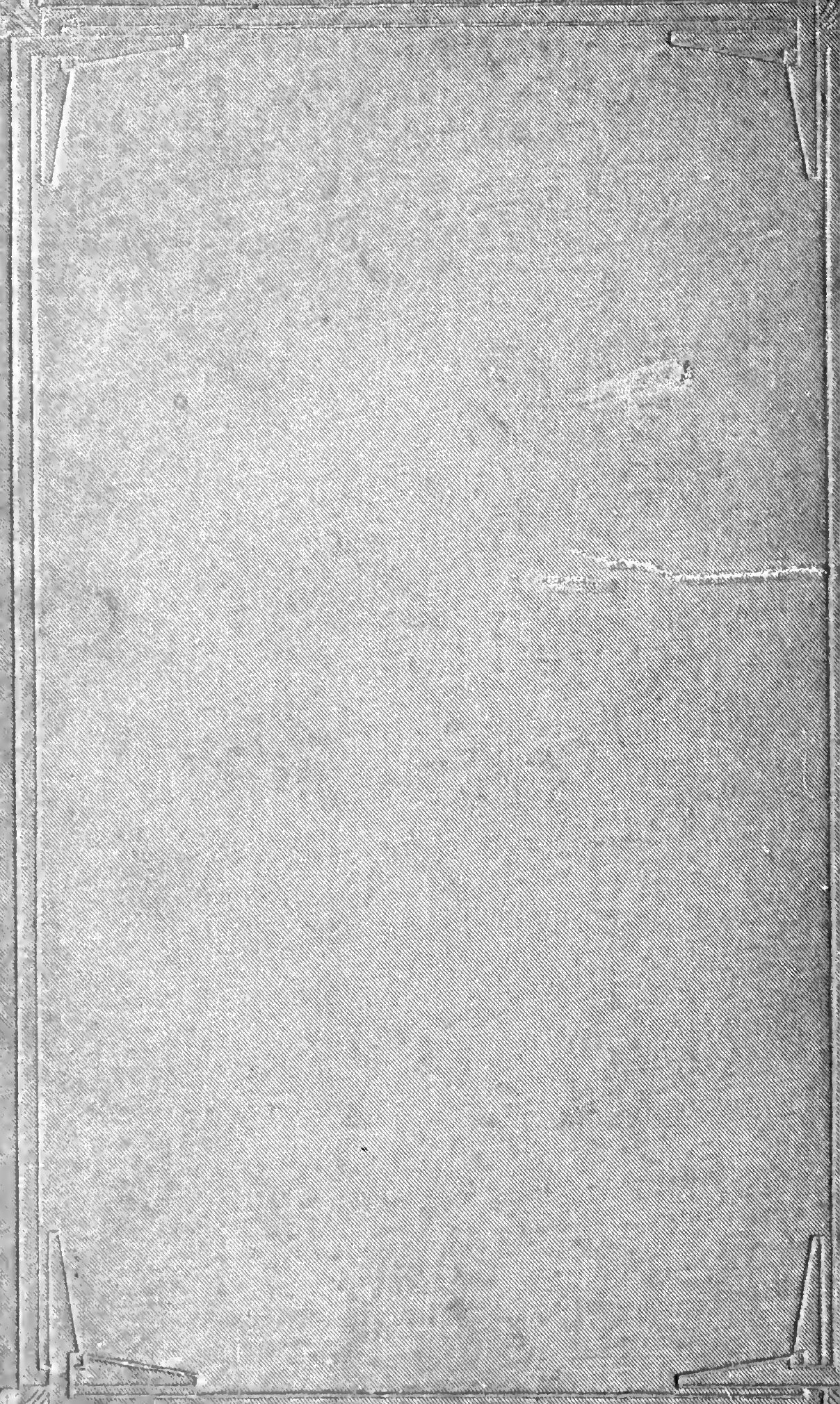

